\title{
AGENDA
}

\section{A Journal of Policy Analysis and Reform}

\author{
Volume 15, Number 3, 2008
}

\section{Contents}

Editors and Editorial Committee

\section{ANALYSIS}

Will we all be Rooned without a Desal Plant? Hanrahan's Lament and the 5 Problem of Urban Water Planning under Climate Change

Donna Brennan

Australia's Transition from Native Forests to Plantations: The Implications 21 for Woodchips, Pulpmills, Tax Breaks and Climate Change

Judith Ajani

Righting Australia's Vertical Fiscal Imbalance: Transferring Public

Hospital Funding as an Option for Reform

Richard Eccleston

\section{ARGUMENT}

Getting Real about Adapting to Climate Change: Using "Real Options" 55 to Address the Uncertainties

Leo Dobes

\section{DEBATE}

Can Urban Water Markets Work? Some Concerns

Lin Crase, Suzanne O'Keefe and Brian Dollery

Can Urban Water Markets Work? An Optimistic View

Hugh Sibly

\section{CONTROVERSY}

Is Policy the Problem or the Solution for Indigenous People? 


\section{RETROSPECT}

Dave Clark (1946-2008): Economist, Larrikin, "Critical Drinker" and Friend

Peter Groenewegen and John Lodewijks

\section{REVIEWS}

A Farewell to Alms by Gregory Clark

Declan Trott

Gunnar Myrdal. An Intellectual Biography by William J. Barber

Selwyn Cornish

Research Without Tears: From the First Ideas to Published Output by John Creedy

Farshid Vahid 


\section{Editors}

Dr William Coleman

Dr Alex Robson

\section{Editorial Committee}

Dr Natasha Cica

Prof. Harry Clarke

Mr James Cox

Dr Anne Daly

Prof. Kevin Davis

Mr Joe Dimasi

Dr Stephen Grenville

Dr Arthur Grimes

Dr Gary Johns

Prof. Margaret Nowak

Prof. Margaret Otlowski

Mr Claude Piccinin

Dr Grant Scobie

Dr Tony Sorenson
College of Business and Economics, ANU

College of Business and Economics, ANU
Periwinkle Projects, Hobart

Department of Economics and Finance, La Trobe University

Independent Pricing and Regulatory Tribunal of New South Wales, Sydney

Division of Management and Technology,

University of Canberra

Department of Finance, University of Melbourne

Regulatory Affairs Division, ACCC

Lowy Institute, Sydney

Motu Research, Wellington

ACIL Tasman, Melbourne

Graduate School of Business, Curtin University of Technology

Faculty of Law, University of Tasmania

Water Services Association of Australia

New Zealand Treasury, Wellington

Department of Geography and Planning, University of New England 



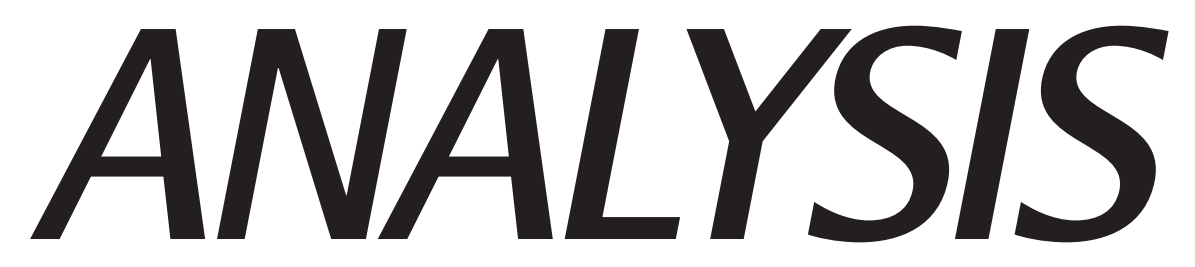





\title{
Will we all be Rooned without a Desal Plant? Hanrahan's Lament and the Problem of Urban Water Planning under Climate Change
}

\author{
Donna Brennan ${ }^{1}$
}

\begin{abstract}
Given the uncertainty of climate forecasts there is a danger of overly pessimistic forecasts justifying overly large and early investment in desalination plants. If the recent weather patterns turn out to be just a drought, water utilities will find themselves with redundant desalination plants or, worse still, a commitment to pay high costs to desalinate water when dams are regularly spilling. A case study of Western Australia argues that the construction of the touted second desalination plant will mean dams will spill significantly one year in two if the climate follows the average patter of the years 1975-2006. Further, the climate assumptions that are used to justify the plant imply a long-run cost potentially high enough to eliminate the demand for the water supplied by the plant.
\end{abstract}

\section{Introduction}

'If rain don't come this month,' said Dan,

And cleared his throat to speak -

'We'll all be rooned,' said Hanrahan,

'If rain don't come this week.'

'If we don't get three inches, man,

Or four to break this drought,

We'll be rooned,' said Hanrahan,

'Before this year is out.'

Said Hanrahan, J O'Brien, 1921

O'Brien's poem tells the story of a very pessimistic farmer whose obsession with the weather was probably understandable, given that his cropping fortune depended on getting the right quantity of seasonal rainfall at the right time. For managers of public water utilities and their responsible ministers, the stakes of the rainfall gamble are also very high. They take the blame when a city runs short of water in a country where urban water supply seems to be a matter of

\footnotetext{
${ }^{1}$ Centre for Agricultural Policy, Institute for Policy and Strategy for Agriculture and, Vietnam, donnabrennan@iinet.net.au
} 
politics rather than of economics. The difference, however, between Hanrahan's situation and that faced in the public water sector is that utilities can now take action to protect themselves from the vagaries of the weather by investing in desalination, a climate-independent technology. Unfortunately, there is little to protect society from the Hanrahanian pessimism that seems to be ingrained in those who have a stake in the Australian weather. As Hanrahan found out soon enough, too much rainfall can lead to ruin too:

...In God's good time down came the rain...

$\ldots$ and every creek a banker ran

And dams filled over top.

'We'll all be rooned,' said Hanrahan

'If this rain doesn't stop.'

The rainfall probability distribution also poses substantial risk to investors in desalination technology. Cooley et al. (2006) report the case of a desalination plant built in Santa Barbara, California, in response to a prolonged drought, that was shut down shortly after it began operation because the drought broke and it was deemed too expensive to run compared to conventional supplies. In the two weeks prior to the announcement of the successful contractor for construction of Sydney's 80 gigalitre (GL) per annum desalination plant, heavy rains had recharged Sydney's dams by 328GL (two-thirds of annual consumption). In this case, no change was made to the construction schedule on the grounds that the desalination plant was still justified to compensate for a reduction in rainfall associated with climate change. However, it remains to be seen how palatable the high costs of running the desalination plant will be if Warrangamba dam is full when the plant is completed.

The trade-off between the cost of supply failure if it doesn't rain, compared to the financial burden of redundancy if it does, has economic and political dimensions. A large proportion of urban water demand in Australia is used outdoors and the strategy for addressing short-term supply failure has been to impose restrictions on outdoor use. Water restrictions impose a welfare cost on the consumer, such as a loss of utility from outdoor gardens and the time cost of hand-watering. Based on decisions made in Western Australia in recent years, the perceived political costs of urban water restrictions are substantially higher than this. Whilst there is an argument for reserve capacity as an insurance policy where there is a perceived high cost of failure, there has been no scrutiny of supply-augmentation decisions made by planners regarding the economic trade-off of augmentation vs. supply failure.

In days past it would have been possible to measure the perceived value of supply failure by comparing expenditure on system capacity against the probability that failure will occur; but this is no longer possible because the probability of rainfall outcomes can no longer be securely based on the historical 
climatic record. Thus the 'climate change' issue seems to present an opportunity for Hanrahan's descendents to assume whatever they like about the future catchment yield, so making it is possible to justify substantial investment in desalination technology that may have questionable economic foundations. In Victoria, the calculations for the desalination plant there are based on future catchment yield being defined by the mean of the previous three years (Department of Sustainability and the Environment 2007). In Perth, the Water Corporation recently changed the historical period used to assess future system yield from a nine-year (1997-2005) average to a six-year (2001-06) average, arbitrarily dropping the wettest year in recent history (2000) and adding the driest (2006), thus ensuring an additional 23GL 'shortfall' in the yield of the conventional sources.

Even if political processes deem that an ultra-conservative, ruler-and-pen approach to forecasting the climate is acceptable, there is an economic-efficiency problem if the assumption is not applied consistently across water management. If it is reasonable to assume that the current drought will last forever, then the implications for 'long-run marginal cost', and thus efficient water pricing, are substantial: for even though urban water demand is relatively inelastic, the extent of the price increase rationally necessitated by climate change may reduce demand sufficiently to make the rush of current desalination construction planning across the country surplus to requirements. If only the economic regulators would adopt the same climate forecasts as the water utilities!

This paper presents an analysis of these issues using a case study of the proposed second desalination plant to be built in Western Australia, at Binningup. The aim of the paper is to highlight the need for more rigour and more consistency in the planning and pricing of urban water, especially given the prospect of climate change. The next section provides a brief overview of the climate situation in Western Australia. The magnitude of uncertainty regarding climate and catchment yield and its implications for urban water-supply planning are then demonstrated using a simple balance sheet of water supply and demand under current institutional arrangements. A more rigorous assessment of system yield and risk of supply failure is then presented, which demonstrates the relationship between assumptions about the probability-distribution of catchment yield, the timing of supply augmentation, and the cost of supplying urban water over the medium term. There is no attempt in the paper to provide a complete economic analysis of the problem, because of lack of information on the economic cost of supply failure. However, the long-run marginal-cost implications associated with these climate and supply-augmentation assumptions are calculated and compared to prices currently paid by consumers. 


\section{Predicting the climate}

Climate-change scientists have forecast a gloomy outlook for rainfall and Perth metropolitan water supplies in the $21^{\text {st }}$ century. A reduction in annual rainfall of up to 20 per cent by 2030 is predicted in the south-west of Australia, compared to a maximum reduction of 10 per cent in the eastern states; and Perth urban water supplies face greater insecurity (Pittock 2003). In 1998 the WA government set up the Indian Ocean Climate Initiative (IOCI), a collaboration between the CSIRO, the Bureau of Meteorology and Western Australian government agencies to assess climate-change issues facing south Western Australia, and provide interpretation of, and judgment on, the uncertainties surrounding climate-change science. This group has developed models to downscale the results of global climate-change models to the weather patterns of the south-west of Western Australia and to forecast the impact on surface-water inflows into metropolitan dams. The downscaled rainfall models have been shown to fit well to the post-1975 rainfall sequence, during which there has been an increase in the frequency of the driest winter-weather patterns and a reduction in the frequency of various wetter-winter patterns (Charles, Bates and Hughes 1999; and Steve Charles July 2007, personal communication). An 11 per cent reduction in mean rainfall is predicted for the region by the middle of the $21^{\text {st }}$ century compared to the recent (post-1975) average. Using a rainfall-runoff model of Stirling Dam, researchers have predicted that the impact of an 11 per cent reduction in rainfall will be a 31 per cent reduction in streamflows in the period 2042-62 compared to the period 1982-2002. However, there is some uncertainty in the predicted outcome because of uncertainty regarding the impact of climate change on evapotranspiration. If potential evaporation increases by 10 per cent under a warmer climate regime, then the predicted streamflow reduction is $41 \%$ (Berti et al. 2004; Bari et al. 2005). These predicted changes represent expectations 50 years from now.

In its source-development planning, the Water Corporation has adopted the use of a recent historical sequence, which was initiated in a major planning document (Water Corporation 2005) when all system yields were expressed for two climate-change scenarios; one being the post-1975 sequence and the other a more pessimistic scenario represented by the post-1997 sequence (Water Corporation 2005). In response to the extreme weather conditions experienced in 2006, which saw the lowest winter inflows on record, the Water Corporation has revised its estimates of system yield for planning purposes and now uses the climate average since 2001, including 2006. Inflows in the winter of 2000 were among the largest in recent history, and if the ruler-and-pen approach included the year 2000, the mean system yield would be $28 \%$ higher than for the '2001-06' scenario. In fact, the mean system yield for the 2000-06 scenario is similar to the mean system yield for 2050 predicted by the IOCI models. 
In the analysis provided in this paper, four system yield scenarios are presented. These are, in order of decreasing system yield, the 1975-2006 climate sequence, the 2000-06 sequence, the IOCI worst-case scenario, and the Water Corporation's current planning yield, based on the 2001-06 climate sequence.

\section{The effect of climate uncertainty on the urban water balance in Western Australia}

It is difficult to tell a simple story of the water-balance situation in Western Australia because of inconsistency between the governing agencies. On the demand side, the reality is that water is too cheap and demand is too high; and even considering the fact that consumers are on two-day per week sprinkler restrictions, unrestricted per-capita urban demand would probably be lower than current demand if price signals were corrected. ${ }^{2}$ On the supply side, one of the major sources of water for Perth, the Gnangara Mound, ${ }^{3}$ is in a serious state of degradation, and the Department of Water has been found by the Environmental Protection Authority to be in breach of Ministerial conditions regarding groundwater levels that were put in place to protect water-dependent ecosystems (Environmental Protection Authority of Western Australia 2007a and 2007b). The Department of Water (Department of Water 2007) has adopted the position that groundwater decline on the Mound is largely due to climate change (and therefore not their fault), while at the same time the amount of water allocated from the Mound in recent years has been allowed to increase to compensate for the climate-change impacts on surface-water reserves. That is, one of the key responses to the recent water shortages in Perth has been to mine the Gnangara Mound, rather than to reduce allocations in response to a drying climate. The Gnangara story is more complex again, because the Water Corporation is the highest-value user on the Mound and only represents 48 per cent of consumptive uses (Marsden Jacob 2006). With stronger governing institutions the amount of water allocated to the Water Corporation in recent years may well have increased, but in lieu of other consumptive uses rather than environmental uses.

The focus of this paper is on the decision-making of the water utility; and therefore, rather than focus on the optimal resolution to the above issues from a social point of view, the approach taken is to use the planning context faced

\footnotetext{
2 According to simulations from a model of household water demand reported in Brennan (2006).

3 The Gnangara Mound is a system of four aquifers underlying the north metropolitan and peri-urban area of Perth and is the largest single source of water for urban supply, as well as a major supplier of water for irrigation of fresh produce supplied to the Perth market.
} 
by the Water Corporation. ${ }^{4}$

The mean water-balance situation, given current institutional arrangements, is shown in Table 1 for the four climate scenarios discussed in the previous section as well as the complete (post-1911) historical record. The data in this table reflect average system yield and provide a simple exposition of the impact of climate-change assumptions on system yield and the planning deficit; hence the pressure for early augmentation. Note that the difference in system yield between the best- and worst-case climate assumptions in Table 1 is 60GL, which is a large amount of water by urban planning standards - for example, the capacity of the desalination plant at Kwinana is 45GL.

The investment in the first desalination plant, at Kwinana, was prompted by the acknowledgement that the complete historical sequence was no longer relevant for planning purposes. Analysis by the IOCI had shown a dramatic change in weather in the post-1975 sequence and the difference in yield between historic and post-1975 climate has a dramatic impact on yield. ${ }^{5}$ In the absence of this first desalination plant, urban supply was insufficient to meet projected 2007 demand for all scenarios except the post-1975 climate. The additional 45GL provided by the investment in desalination at Kwinana has provided sufficient (average) capacity to meet 2007 demand levels for all climate scenarios. However, by 2010 demand growth would be sufficient to cause a significant deficit in capacity under the six-year climate scenario. This climate scenario is necessary to justify the current decision to construct a second desalination plant to augment water supply in 2011. If the IOCI predictions are taken to be the 'best science' relating to the matter, there is no justification for augmentation in $2011 .^{6}$

\section{System reliability and the effect of climate-change assumptions}

The use of mean capacity estimates does not reflect the short-term water situation associated with below-mean dam storage levels, which elevates the risk of system failure in the short-to-medium term and is arguably the main driver of recent investments in desalination in Australia. Neither does it assess the risk of dam spills that can occur with a sequence of wet years. A system model was developed

\footnotetext{
${ }^{4}$ The current allocation rule for Gnangara groundwater, which allocates water above historical levels on a sliding scale according to dam reserves, is assumed to be in place. Whilst a draft resolution to allocation issues on Gnangara Mound is expected to be produced by 2009 (Department of Water 2008), if seasonal trade is institutionalised then a market-based solution may show the same pattern of urban water use as the current sliding-scale rule.

${ }^{5}$ The magnitude of this impact led to the so-called water crisis of the drought year 2001. Five years earlier, the Water Corporation had issued a planning document that declared that existing source developments were sufficient water for the foreseeable future (Stokes et al. 1995). In that document, the issue of climate change was mentioned but not factored into the analysis. The ultra-conservative approach now being taken by the Water Corporation may reflect this experience.

6 There is a slight deficit for the worst-case scenario, but these climate forecasts are expected to represent yield in 2050, with a gradual decline from the experience from the past two decades.
} 
to assess the risks associated with timing of investment in the second (Binningup) desalination plant proposed for Western Australia under different climate-change assumptions. Inputs to the model are an assumed probability-distribution of catchment yields (representing each climate scenario), projected urban demand and availability of water from groundwater sources (both based on existing institutional arrangements). The model tracks dam storage levels over the next 10 years and measures the frequency of dam spills and of urban-supply restrictions (triggered by low storage levels). Each scenario is analysed from 1000 random sequences of weather patterns, drawn from the probability distribution for that climate scenario. The detail of the simulation model is described in Brennan (2008).

\section{Table 1: Average water-balance situation for a range of climate scenarios}

\begin{tabular}{|c|c|c|c|c|c|}
\hline & \multirow[t]{3}{*}{ Historical } & & \multicolumn{2}{|c|}{ Climate scenarios: } & \multirow{3}{*}{$2001-06$} \\
\hline & & \multirow[t]{2}{*}{ 1975-2006 } & \multicolumn{2}{|c|}{$\begin{array}{l}\mathrm{IOCl} \text { prediction for } \\
2050\end{array}$} & \\
\hline & & & Baseline & Worst-case & \\
\hline Surface Water (SW) Yield GL & 316 & 184 & 127 & 109 & 96 \\
\hline Groundwater (GW) Yield GL & 105 & 137 & 164 & 165 & 165 \\
\hline Capacity prior to Kwinana desal plant & 421 & 321 & 291 & 274 & 261 \\
\hline Planning deficit 2007 prior to Kwinana desal plant & 0 & 0 & 13 & 30 & 43 \\
\hline Capacity after Kwinana desal plant & 466 & 366 & 336 & 319 & 306 \\
\hline Planning deficit 2007 & 0 & 0 & 0 & 0 & 0 \\
\hline Planning deficit 2011 & 0 & 0 & 0 & 3 & 16 \\
\hline Planning demand 2007 & 304 & 304 & 304 & 304 & 304 \\
\hline Planning demand 2011 & 322 & 322 & 322 & 322 & 322 \\
\hline
\end{tabular}

Source: Data provided by Water Corporation (Michael Loh, Personal Communication, October 2006) and Water Corporation (2005). Source of IOCI climate scenarios discussed in text.

In all of the scenarios, it is assumed that the Water Corporation's proposed new desalination plant is providing water at full capacity in the summer of 2011/12. It is assumed that both desalination plants run at full capacity even when dams are full. While in reality these desalination plants would be switched off if rainfall significantly recovered from recent years, the assumption of full utilisation is useful to illustrate the extent of the potential surplus associated with desalination investment.

Results of the analysis are presented in the Tables 2 and 3. Table 2 shows the (unrestricted) demand forecast over time, and the risk of a sprinkler ban in each year for each climate scenario. As the climate assumptions become more conservative, the risk of a sprinkler ban increases. For all but the driest climate scenario, the risk of a sprinkler ban is already improving in the period prior to 2011. This suggests that the system reliability is in a state of recovery from the low dam reserves of 150GL at the end of the 2007 summer, due to the boost in supply provided by the Kwinana desalination plant. This confirms the average water-balance analysis presented in Table 1 - water in 2011 is not in a net-deficit 
situation for these climate scenarios. In contrast, for the most conservative climate scenario, the risk of sprinkler bans increases over the period prior 2011. The augmentation of supply reduces the risk of a sprinkler ban down to 3.4 per cent for this scenario in 2010/11. This would not be considered a very high risk in most capital cities for Australia; for example, planning for augmentation is usually done on a sprinkler-ban risk tolerance of one year in 25 (ACTEW 2004). However, in Western Australia planning is based on a one in 200 tolerance to the risk of sprinkler bans.

Also shown in Table 2 is average dam storage level, as measured at the end of winter (October), for each climate scenario. The simulation begins at the start of winter 2007 and thus has had two winters by the end of October 2008. There is already a substantial difference in end-of-winter storage levels for all scenarios. Compared to the actual storage level of 220GL at the end of October 2006, some recovery of dam storage levels is expected even for the most conservative of climate scenarios by winter 2008 . However, there is already a large divergence in recovery of dam reserves by 2008 and this divergence increases over time. Expected end-of-winter dam levels for the most conservative climate scenario remain stagnant (and combined with growing demand imply a deteriorating reliability). There is a boost to dam storage levels in all scenarios following supply augmentation in 2011, because the new desalination plant leads to a reduction in the drawdown of dams. For the 1975-2006 climate scenario, dam storage levels approach capacity over the simulation period.

Table 3 presents the analysis of the risk of 'dams running over top'. First, the risk of winter spills occurring is measured. Dams inevitably spill in high-flow years if they have a high inflow-to-storage ratio, and spills from the two dams in the Perth metropolitan system (Churchman and Stirling) that have high inflow-to-storage ratios were not included in the measures shown here. The risk of winter spills shows the risk that one of the other dams will be full enough to spill in a high-flow winter. In many cases these spills are not very substantial; so, in order to gauge events that involve serious loss of water (and would raise the question as to why the desalination plant is still running), the risk of spills exceeding 10GL was also calculated.

The risk of winter spills is very high for the 1975-2006 climate, and is exacerbated after 2011 with the introduction of the second desalination plant. In 2012, dams are expected to spill in 66 per cent of years. For the 2000-06 climate scenario, the risk of dam spillage in the near future is 6-7 per cent, but it increases to 27 per cent in 2012 following the accumulation of surface water once the second desalination plant is in use. For the IOCI worst-case climate scenario, the risk of dam spillage is substantially lower. For the Water Corporation's planning scenario (2001-06 climate) there is virtually no risk of dams spilling because system yield is so low. 
Table 2: Simulated water availability under different climate scenarios assuming second desalination plant arrives in 2011/12.

\begin{tabular}{|c|c|c|c|c|c|c|c|c|c|}
\hline & $2007 / 08$ & $2008 / 09$ & $2009 / 10$ & $2010 / 11$ & $2011 / 12$ & $2012 / 13$ & $2013 / 14$ & $2014 / 15$ & $2015 / 16$ \\
\hline Demand & 296.23 & 301.59 & 307.23 & 312.54 & 316.63 & 321.46 & 326.11 & 330.86 & 335.59 \\
\hline \multicolumn{10}{|c|}{ Calculated risk of a sprinkler ban: } \\
\hline $\begin{array}{l}\text { 1975-2006 } \\
\text { climate }\end{array}$ & $0.9 \%$ & $0.5 \%$ & $0.2 \%$ & $0.2 \%$ & $0.0 \%$ & $0.0 \%$ & $0.0 \%$ & $0.0 \%$ & $0.0 \%$ \\
\hline 2000-06 climate & $2.8 \%$ & $2.7 \%$ & $1.9 \%$ & $1.2 \%$ & $0.1 \%$ & $0.1 \%$ & $0.0 \%$ & $0.0 \%$ & $0.0 \%$ \\
\hline $\begin{array}{l}\text { IOCI worst-case } \\
\text { climate }\end{array}$ & $5.1 \%$ & $5.4 \%$ & $4.3 \%$ & $4.4 \%$ & $0.9 \%$ & $0.0 \%$ & $0.1 \%$ & $0.0 \%$ & $0.1 \%$ \\
\hline 2001-06 climate & $10.1 \%$ & $12.4 \%$ & $14.0 \%$ & $16.2 \%$ & $3.4 \%$ & $0.8 \%$ & $1.0 \%$ & $0.8 \%$ & $1.4 \%$ \\
\hline \multicolumn{10}{|l|}{ October storage } \\
\hline $\begin{array}{l}\text { 1975-2006 } \\
\text { climate }\end{array}$ & 395.50 & 437.38 & 471.86 & 499.92 & 548.65 & 584.60 & 605.20 & 622.03 & 633.95 \\
\hline 2000-06 climate & 316.9 & 333.1 & 344.4 & 351.0 & 391.3 & 420.0 & 434.4 & 446.2 & 452.8 \\
\hline $\begin{array}{l}\text { IOCI worst-case } \\
\text { climate }\end{array}$ & 284.27 & 291.76 & 295.92 & 296.22 & 331.36 & 352.66 & 358.68 & 362.20 & 361.13 \\
\hline 2001-06 climate & 245.75 & 245.52 & 244.90 & 242.27 & 272.31 & 288.20 & 289.36 & 288.05 & 283.39 \\
\hline
\end{tabular}

Table 3: Simulated risk of dam spills assuming second desalination plant arrives in 2011/12.

\begin{tabular}{|c|c|c|c|c|c|c|c|c|c|}
\hline & $2007 / 08$ & 2008/09 & $2009 / 10$ & $2010 / 11$ & $2011 / 12$ & $2012 / 13$ & $2013 / 14$ & $2014 / 15$ & $2015 / 16$ \\
\hline \multicolumn{10}{|l|}{$\begin{array}{l}\text { Risk of winter } \\
\text { spills }\end{array}$} \\
\hline $\begin{array}{l}1975-2006 \\
\text { climate }\end{array}$ & $31 \%$ & $37 \%$ & $41 \%$ & $45 \%$ & $62 \%$ & $66 \%$ & $62 \%$ & $63 \%$ & $61 \%$ \\
\hline 2000-06 climate & $6 \%$ & $6 \%$ & $7 \%$ & $9 \%$ & $20 \%$ & $27 \%$ & $26 \%$ & $26 \%$ & $23 \%$ \\
\hline $\begin{array}{l}\mathrm{IOCI} \text { worst-case } \\
\text { climate }\end{array}$ & $1 \%$ & $1 \%$ & $2 \%$ & $2 \%$ & $5 \%$ & $7 \%$ & $8 \%$ & $8 \%$ & $7 \%$ \\
\hline 2001-06 climate & $0.1 \%$ & $0.0 \%$ & $0.0 \%$ & $0.0 \%$ & $0.3 \%$ & $0.5 \%$ & $0.8 \%$ & $0.2 \%$ & $0.0 \%$ \\
\hline \multicolumn{10}{|l|}{$\begin{array}{l}\text { Risk of Spills > } \\
\text { 10GL }\end{array}$} \\
\hline $\begin{array}{l}1975-2006 \\
\text { climate }\end{array}$ & $16 \%$ & $21 \%$ & $28 \%$ & $32 \%$ & $45 \%$ & $54 \%$ & $52 \%$ & $53 \%$ & $53 \%$ \\
\hline 2000-06 climate & $1 \%$ & $1 \%$ & $2 \%$ & $2 \%$ & $6 \%$ & $8 \%$ & $10 \%$ & $11 \%$ & $10 \%$ \\
\hline $\begin{array}{l}\mathrm{IOCl} \text { worst-case } \\
\text { climate }\end{array}$ & $0 \%$ & $0 \%$ & $0 \%$ & $0 \%$ & $1 \%$ & $1 \%$ & $2 \%$ & $1 \%$ & $2 \%$ \\
\hline 2001-06 climate & $0.0 \%$ & $0.0 \%$ & $0.0 \%$ & $0.0 \%$ & $0.0 \%$ & $0.1 \%$ & $0.0 \%$ & $0.0 \%$ & $0.0 \%$ \\
\hline \multicolumn{10}{|l|}{ Mean Spills** } \\
\hline $\begin{array}{l}\text { 1975-2006 } \\
\text { climate }\end{array}$ & 5.09 & 7.86 & 12.05 & 14.72 & 27.29 & 34.58 & 35.51 & 37.00 & 36.49 \\
\hline 2000-06 climate & 0.33 & 0.44 & 0.60 & 0.60 & 1.71 & 2.42 & 2.99 & 3.00 & 3.00 \\
\hline $\begin{array}{l}\text { IOCI worst-case } \\
\text { climate }\end{array}$ & 0.05 & 0.05 & 0.12 & 0.05 & 0.22 & 0.33 & 0.48 & 0.41 & 0.35 \\
\hline 2001-06 climate & 0.00 & 0.00 & 0.00 & 0.00 & 0.00 & 0.02 & 0.01 & 0.00 & 0.00 \\
\hline
\end{tabular}


The high risk of dam spills for the 1975-2006 climate also corresponds to a high risk of spills that are of a large volume. If the supply augmentation occurs in 2011 , the risk of dams spilling more than 10GL of water in 2002 is 54 per cent. In the case of the 2000-06 climate, the risk of dam spills exceeding 10GL in 2012 is 8 per cent. For the drier climate scenarios the risk is insignificant.

A comparison of the 2000-06 climate scenario with the 2001-06 scenario highlights the current decision-making dilemma regarding climate uncertainty. Adding the relatively wet year of 2000 has a substantial impact on the apparent desirability of supply augmentation. The 2001-06 climate scenario implies that the probability of a sprinkler ban is 16 per cent in 2010, prior to the introduction of the new desalination plant. In contrast, the 2000-06 scenario implies that there is little risk of a sprinkler ban even before the plant is introduced, and the risk of dams spilling more than 10GL per annum is 10 per cent by 2013. Using the 'ruler and pen' approach to climate forecasting means that our estimate of whether we will be 'rooned' by drought or 'rooned' by desalination obsolescence all hinges on whether or not we include 2000 in the time series.

\section{Implications for long-run marginal cost}

Climate change will change the long-run cost of any given amount of water supply.

The Western Australian economic regulator has adopted the perturbation or 'Turvey' approach to the calculation of long-run marginal cost (Economic Regulatory Authority 2005). The approach accounts for the nature of water-supply infrastructure, including lumpiness in augmentation and jointness in integration, as well as the inevitability of supply expansion. Turvey (1976) suggested that long-run marginal cost for water is a dynamic cost which relates to the effect of demand growth on the rate at which the water-supply system must expand. The perturbation method works out the capital-expenditure program required to meet forecast growth in demand and compares it to a second capital-expenditure program associated with a smaller (or larger) forecast pattern of demand. Long-run marginal cost is calculated as the difference in the net present value of costs, divided by the difference in net present value of quantity demanded for the two scenarios. The Turvey approach was used to assess the potential impact of climate assumptions on the calculated LRMC.

For this exercise, the baseline forecast demand was based on the Water Corporation's per-capita demand assumption and assumed to grow with population growth. Growth assumptions in the medium term were based on demographic forecasts (Western Australian Planning Commission 2005). Beyond 2031, growth was assumed to continue at the same growth rate as in 2031. The calculations start in 2011, when the first feasible capital expenditure can occur, which is assumed be the desalination plant at a cost of $\$ 955$ billion (Western 
Australian Government 2007). Subsequent augmentation is based on the source developments ${ }^{7}$ costed in Water Corporation (2005), with costs measured in 2011 dollars for consistency. A 100-year capital-expenditure program was examined, with desalination as the augmentation source after available conventional sources have been exhausted. The operating cost of desalination is assumed to be $\$ 1.04$ per $\mathrm{kL}$, which is significantly higher than the (Water Corporation 2005) estimate of 40-44 cents per $\mathrm{kL}$, not just because of sharp increases in nominal energy prices over the time period, but also because of the fact that the cost quote for the Kwinana plant does not allow for the cost of renewable energy. ${ }^{8}$ A discount rate of 6 per cent was assumed.

Results are presented in Table 4. Compared to a 1975-2006 climate scenario, which provides an LRMC of $\$ 0.78$ per $\mathrm{kL}$, the LRMC associated with the Water Corporation's 2001-06 climate scenario is $\$ 2.19$ per kL.

These costs can be compared with the prices set recently by the economic regulator in Western Australia (Economic Regulatory Authority 2008). These prices are based on an earlier price determination (Economic Regulatory Authority 2005) that had been adjusted for inflation. The previous enquiry based the LRMC calculation on assumptions that are now out of date (including the assumption that the South West Yarragadee would go ahead ${ }^{9}$ and yield more than 45GL, and the assumption that climate would be somewhere between post-1975 and post-1997 historical means ${ }^{10}$ ).

Projected nominal urban-water prices for 2011 are shown in Figure 1. Because of the inclining block tariff structure it is necessary to overlay the graph with a depiction of the pattern of household consumption. On the right-hand axis is the cumulative distribution of household consumption, indicating the proportion of households whose consumption is less than, or equal to, the annual volume shown on the horizontal axis. Around 93 per cent of households consume 550kL or less, and are therefore subject to prices of $\$ 1.03$ per $\mathrm{kL}$ or less at the margin. This is less than half the long-run cost associated with a climate-change assumption adopted by the Water Corporation to justify its capital expenditure on another desalination plant.

\footnotetext{
7 Specifically the Wellington Dam upgrade; Brunswick Dam; Eglinton Yanchep and Gingin borefields; and managed aquifer recharge.

8 The deal involving purchase of power from a wind farm was made after the electricity had already sold the green component of its energy as renewable-energy certificates to the electricity utility (Tony Stewart, Office of Energy, personal communication, June 2007).

9 The Water Corporation's preferred supply augmentation was to tap the Yarragadee aquifer in the south-west of the state and connect it to the metropolitan infrastructure using a $105 \mathrm{~km}$ pipeline. The environmental-approval processes for this proposal took five years and there was considerable controversy both in the scientific community and in the public, culminating in a decision by the WA Premier to not allow development of the proposal.

${ }^{10}$ (Greg Watkinson, personal communication, 2006). The post-1997 yield was previously the worst-case climate scenario (Water Corporation 2005) and mean yields are similar to the mean yield for the IOCI baseline forecast.
} 
Table 4: Calculation of long-run marginal cost of bulk water supply for different climate assumptions, in 2011 dollar-terms

\begin{tabular}{|c|c|c|c|c|}
\hline & & \multicolumn{3}{|c|}{ Climate scenario } \\
\hline & & 1975-2006 & $\mathrm{IOCI}$ baseline & 2001-06 (WC) \\
\hline Increment, 15kL/capita & $\begin{array}{l}\text { Additional } \\
\text { Capital } \\
\text { expenditure } \\
\$ \mathrm{~m}\end{array}$ & 280 & 829 & 899 \\
\hline \multirow[t]{3}{*}{ NPV of additional water $611 \mathrm{GL}$} & $\begin{array}{l}\text { Additional } \\
\text { Operating } \\
\text { expenditure } \\
\$ \mathrm{~m}\end{array}$ & 243 & 416 & 527 \\
\hline & $\begin{array}{l}\text { Total } \\
\text { Additional } \\
\text { Cost \$m }\end{array}$ & 523 & 1,245 & 1,426 \\
\hline & $\begin{array}{l}\text { Marginal } \\
\text { cost } \$ / k L\end{array}$ & 0.86 & 2.04 & 2.33 \\
\hline Decrement, $15 \mathrm{~kL} /$ capita & $\begin{array}{l}\text { Saved } \\
\text { Capital } \\
\text { expenditure } \\
\$ \mathrm{~m}\end{array}$ & 285 & 623 & 689 \\
\hline \multirow[t]{3}{*}{ NPV of saved water $611 \mathrm{GL}$} & $\begin{array}{l}\text { Saved } \\
\text { Operating } \\
\text { expenditure } \\
\$ \mathrm{~m}\end{array}$ & 147 & 375 & 559 \\
\hline & $\begin{array}{l}\text { Total Saved } \\
\text { Cost } \$ \mathrm{~m}\end{array}$ & 432 & 998 & 1248 \\
\hline & $\begin{array}{l}\text { Marginal } \\
\text { cost } \$ / k L\end{array}$ & 0.71 & 1.63 & 2.04 \\
\hline Long-Run Marginal Cost & & 0.78 & 1.83 & 2.19 \\
\hline
\end{tabular}

Figure 1: Projected tariff structure for 2011 and distribution of household consumption

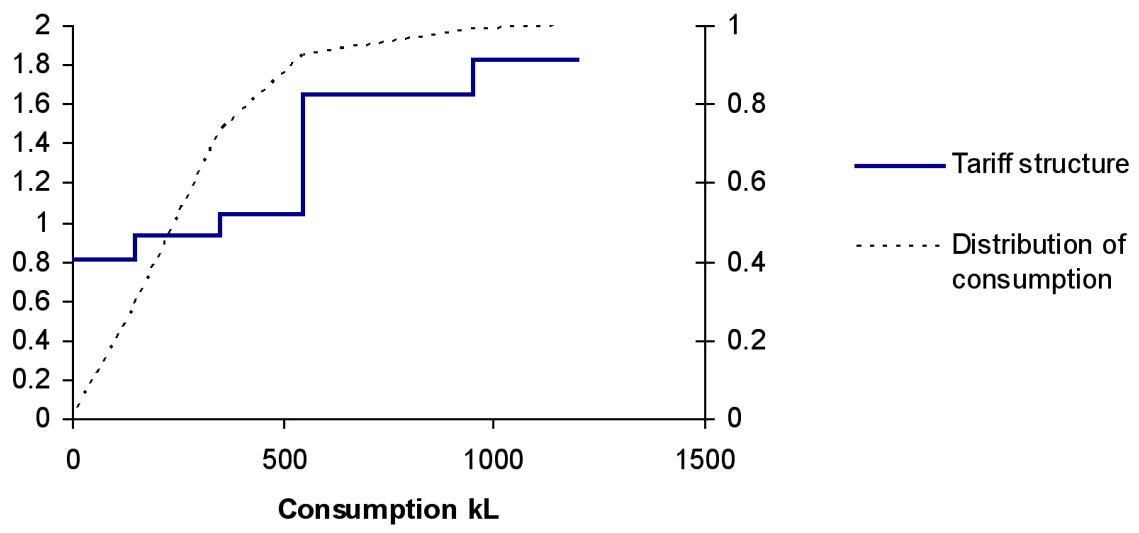


The establishment of correct price incentives will therefore require a doubling of prices. Even if consumer demand is relatively price inelastic, a significant impact on per-capita consumption is likely. For example, it is well established that demand is more inelastic for indoor uses, with indoor (or winter) elasticity generally less than -0.05 , and outdoor demand elasticity can be higher, such that measures of aggregate household demand elasticity have been reported to be around -.3 to -0.4 (NERA 2001; Arbues et al. 2003; Dalhuisen et al. 2003). About half of water is used for indoor use in Perth. Using an indoor elasticity of -0.05 and an outdoor elasticity of -0.2 , the calculated impact of a doubling of prices is 15 per cent or $23 \mathrm{~kL}$ per capita. ${ }^{11}$

\section{Impact on the risk of a sprinkler ban of aligning prices with climate expectations}

Thus significantly lower demand would be expected if prices were aligned with the LRMC associated with Water Corporation climate expectations. The effect of lower per capita demand on the risk of a sprinkler ban, for the Water Corporation's climate forecast, is shown in Table 6. Even if higher prices were only able to reduce per-capita demand from $155 \mathrm{~kL}$ to $150 \mathrm{~kL}$, the risk of a sprinkler ban in 2010/11 could be reduced substantially from 16.2 per cent to 3.9 per cent. Since the price response to a correction in pricing signals is likely to result in a more significant demand reduction, the risk of a sprinkler ban would be reduced more substantially. Thus, even in the worst of the worst-case climate scenarios, the proposed urgency of the next source would be questioned if prices were adjusted to reflect LRMC.

Table 6: Impact of per-capita demand on the risk of a sprinkler ban, for worst-case (2001-06) climate scenario

\begin{tabular}{crrrrr}
\hline $\begin{array}{c}\text { Assumed } \\
\text { per-capita } \\
\text { demand }\end{array}$ & $\mathbf{2 0 0 7 / 8}$ & $\mathbf{2 0 0 8 / 9}$ & $\mathbf{2 0 0 9 / 1 0}$ & $\mathbf{2 0 1 0 / 1 1}$ & $\mathbf{2 0 1 1 / 1 2}$ \\
\hline 155 & $10.10 \%$ & $10.90 \%$ & $10.20 \%$ & $10.60 \%$ & $2.40 \%$ \\
150 & $5.50 \%$ & $6.30 \%$ & $4.10 \%$ & $3.90 \%$ & $0.70 \%$ \\
145 & $2.70 \%$ & $2.80 \%$ & $1.60 \%$ & $0.50 \%$ & $0.00 \%$ \\
140 & $1.00 \%$ & $1.40 \%$ & $0.50 \%$ & $0.10 \%$ & $0.00 \%$ \\
135 & $0.50 \%$ & $0.30 \%$ & $0.00 \%$ & $0.10 \%$ & $0.00 \%$ \\
\hline
\end{tabular}

\section{Conclusions}

The threat of climate change is a serious concern for water-supply planners, but given the uncertainty surrounding climate forecasts, there is an opportunity for pessimistic interpretation of future climate to justify larger and earlier investment in desalination technology. While there is a lot of uncertainty surrounding climate-change science, one would expect that the body of knowledge that now exists could produce a more rigorous estimate of water-system yield than an

${ }^{11}\left(0.05^{*} 50 \%+0.3^{*} 50 \%\right)^{*} 100 \%=17.5 \% * 155=27.175$ 
arbitrary selection of recent years' data. Since the desalination investments being made across the country are typically of the order of $\$ 1$ billion per plant, the value of information regarding climate forecasts, and arguably the benefit of investing more research in this area, is high.

Given the unscientific manner being used by water-supply planners to predict the climate, the justification for investment is flimsy, especially when the other side of the probably distribution is taken into account. It was demonstrated here that the inclusion of the year 2000 in the time series used to calculate mean system yield can turn Hanrahan's lament on its head. Inclusion of one more year in the time series presently used for planning completely removes the risk of a sprinkler ban and the justification for the proposed augmentation in 2011 and results in a significant risk that the government and water-supply planners could be embarrassed by the opposite problem of dams spilling shortly after a very expensive water-manufacturing plant has been constructed. Worse still, utilities may be committed to keep paying to operate the desalination plant if take-or-pay arrangements have been contracted under public-private-partnership arrangements.

There is good potential for reining in the temptation to overestimate the impact of climate change on system yield through effective economic management. If future system yield is really as dire as the water planners predict, the implications for long-run marginal cost on prices are likely to have significant impact on demand and on the need for investment in desalination. The example shown here demonstrates that if the Economic Regulatory Authority adopted the same water forecast as the Water Corporation in Western Australia and had enough power to force proper LRMC pricing, the current construction of the desalination plant in Western Australia could be at least postponed.

\section{References}

Arbues, F., Garcia-Valinas, M. and Martinez-Espineira, R. 2003, 'Estimation of residential water demand: a state of the art review', Journal of Socio-Economics 32: 61-102.

ACTEW Corporation Ltd 2004, 'Future water options for the ACT region in the $21^{\text {st }}$ Century - An assessment of the need to increase the ACT's water storage', ACTEW Corporation, Canberra, at: <http://www.actew.com.au/ futurewateroptions/documents/assessmentReport.pdf $>$ Accessed 10 January 2008.

Bari, M., Berti, M., Charles, S., Hauck, E. and Pearcey M. 2005, 'Modelling of streamflow reduction due to climate change in Western Australia - a case study', paper presented at the International Congress on Modelling and Simulation MODSIM05, 12-15 December. Available at: 
<http://mssanz.org.au/modsim05/papers/bari.pdf > Accessed 20 July 2007.

Berti, M., Bari, M., Charles, S. and Hauck, E. 2004, 'Climate change, catchment runoff and risks to water supply in the South West of Western Australia', Department of Environment.

Brennan, D. 2006, 'Efficiency and equity implications of Perth's inclining block urban water tariffs', presented at the $50^{\text {th }}$ Australian Agricultural and Resource Economics Society Annual Conference, Sydney, February 2006.

Brennan (2008), 'Desalination, climate change and Hanrahan's lament', Paper presented at the 52nd Conference of the Australian Agricultural and Resource Economics Society, Canberra, 6-8th February, 2008.

Charles, S., Bates, B. and Hughes J. 1999, 'A spatiotemporal model for downscaling precipitation occurrence and amounts', Journal of Geophysical Research 104(D24) 31: 657ff.

Cooley, H., Gleick, P. and Wolf, G. 2006, 'Desalination, with a grain of salt: A Californian Perspective', Pacific Institute, Oakland, California, at $<222$.pacinst.org/reports/desalination> Accessed May 2007.

Dalhuisen, J., Florax, R., de Groot, H. and Nijkamp P. 2003, 'Price and income elasticities of residential water demand: a meta-analysis', Land Economics 79: 292-308.

Department of Sustainability and the Environment 2007, 'Our water, our future: The next stage of the government's water plan', Victorian Government, at <http://www.ourwater.vic.gov.au/pdf/plan/DSEWaterReport.pdf> Accessed July 2007.

Department of Water 2007, 'Environmental management of groundwater abstraction from the Gnangara Mound June 2004-5', Annual Compliance Report to the Environmental Protection Authority, Perth, WA. At $<$ http://portal.water.wa.gov.au/portal/page/portal/WaterManagement/ Groundwater/Gnangara/Content/Gnangara_Compliance_2004-05.pdf>

Department of Water 2008, 'GSS: Gnangara sustainability strategy, Project briefing', at: < http://portal.water.wa.gov.au/portal/page/portal/ gss/GnangaraSustainability Strategy > Accessed 27 January 2008.

Economic Regulatory Authority of Western Australia 2005, 'Final report: Inquiry into urban water and wastewater pricing', Economic Regulatory Authority, Perth.

Economic Regulatory Authority 2008, 'Final report: Inquiry on Water Corporation's tariffs', 16 January 2008. 
Environmental Protection Authority 2007a, 'Report on Waters and River Commission's Environmental management of groundwater abstraction from the Gnangara Mound June 2004-5', Annual Compliance Report, Bulletin 1252, Perth, Western Australia, at: <http://www.epa.wa.gov.au/docs/2477_EPABull1252_S48.pdf>

Environmental Protection Authority 2007b, 'Environmental management of groundwater abstraction from the Gnangara Mound, July 2004-June 2005', Annual Compliance Report, Bulletin 1252, at: <http://www.epa.wa.gov.au/docs/2477_EPABull1252_S48.pdf>

Marsden Jacob Associates 2006, 'Identification of Economic Values Associated with the Groundwater of the Gnangara Mound', report prepared for the Department of Water, WA.

National Economic Research Associates (NERA) 2001, 'A review of Melbourne's water tariffs, A report for the Department of Natural Resources and Environment', Sydney, October.

O' Brien, J. 1921 'Said Hanrahan', Around the Boree Log and Other Verses, Mercier Press/Marino Books, February 1990.

Pittock, B. (Ed.) 2003, 'Climate change - An Australian Guide to the Science and Potential Impacts', Australian Greenhouse Office, at: http://www.greenhouse.gov.au/science/guide/index.html

Stokes, R., Beckwith, J., Pound, I., Stone, R., Coghlan, P. and Ng, R. 1995, 'Perth's water future - A water strategy for Perth and Mandurah to 2021 (with focus on 2010)', Water Corporation of Western Australia, at: $<$ www.watercorporation.com.au/_files/PublicationsRegister/12/ perth_water_future.pdf $>$ Accessed 12 January 2008.

Turvey, R. 1976, 'Analyzing the marginal cost of water supply', Land Economics 52(2): 158-68.

Water Corporation 2005, 'Source Development Plan', Water Corporation, Leederville.

Western Australian Planning Commission 2005, 'Western Australia Tomorrow', population report number 6 .

Western Australian Government 2007, 'Second desalination plant to be State's next major water source', Alan Carpenter Media release 15 May 2007, at: http://www.mediastatements.wa.gov.au/media/media.nsf 


\title{
Australia's Transition from Native Forests to Plantations: The Implications for Woodchips, Pulpmills, Tax Breaks and Climate Change
}

\author{
Judith Ajani ${ }^{1}$
}

\begin{abstract}
Deforestation and the degradation of native forests account for an estimated 20 per cent of Australia's annual net greenhouse-gas emissions. Most of the degradation occurs via chip exports, with the plantation sector having captured 80 per cent of wood processing in Australia. Being perfect substitutes for native forest chips, Australia's maturing hardwood plantations present a major opportunity for mitigating climate change. But this opportunity will not be realised with 'business as usual' forest-policy frames and policy information, which are steering Australia to perverse outcomes favouring investment in an inferior sequestration strategy (plantations) and handicapping the economically superior plantation-processing industry. A major review of the Australian forestry industry in the context of climate change is needed.
\end{abstract}

\section{Introduction}

This paper recommends a major review of the Australian forestry industry in the light of the needs of climate-change policy, and the burgeoning of plantation forestry.

The paper begins with a 'situation and outlook' review of Australia's forestry industry, before turning to the most salient contemporary forest-policy issues; the Federal Government's stance of disengagement; taxation-based plantation managed-investment schemes, and climate change. It identifies, within the Government's proposed emissions trading system, likely counter-productive market signals for climate-change mitigation and forestry-industry productivity.

\section{The plantation wood surge}

Today, Australia's 1.9 million hectare plantation estate (53 per cent softwood and 47 per cent hardwood (ABARE 2008: 18)) supplies two-thirds of the forestry

\footnotetext{
${ }^{1}$ Fenner School of Environment and Society, The Australian National University, judith.ajani@anu.edu.au. I would like to thank Sandy Berry, Margaret Blakers, Naomi Edwards, John Kerin and Gordon MacAulay for their comments on an earlier version of this paper; and Brendan Mackey, Heather Keith and two anonymous referees for their comments. The views presented in this paper are not necessarily theirs and any errors are mine.
} 
industry's wood: native forests now supply only one-third. Further, in the immediate term (over the next two years or so), the Bureau of Rural Sciences (Parsons et al. 2007) projects a 60 per cent increase in plantation supply from its current production; taking plantation supply to 3.4 times the volume of wood currently logged from native forests. With large areas of managed-investment-scheme hardwood plantations established since the mid 1990s coming on stream, Australia is on the cusp of a plantation-wood resource shock.

Australia's plantation-wood production continues to outpace its domestic wood consumption. Since 1990, plantation-wood supply has increased by an average 6.5 per cent per annum (coming off a solid base), whilst the amount of wood used to make all the domestic and imported wood products consumed in Australia grew by an average of only 0.8 per cent per annum (Figure 1).

\section{Figure 1: Plantations supply most of Australia's wood needs}



Source: ABARE Australian Commodity Statistics \& Australian Forest and Wood Products Statistics; Parsons et al. 2007 (BRS plantation wood-supply projections)

Little wonder that the Bureau of Rural Sciences' projections indicate that Australia's plantation resources are currently being logged below capacity (Figure 1). According to the Bureau's projections and ABARE's plantation wood-production data, 2 million $\mathrm{m}^{3}$ of mature plantation wood remained unlogged in 2007: equivalent to a quarter of the current annual native-forest log cut. 
Under-logging in the softwood estate explains 60 per cent of today's unused supply (Table 1). ${ }^{2}$

Table 1: Estimated under-use of Australian plantation wood - 2006/07

\begin{tabular}{|c|c|c|c|c|}
\hline & $\begin{array}{r}\text { Actual production } \\
2006 / 07 \\
\text { (million } \mathrm{m}^{3} \text { p.a.) }\end{array}$ & $\begin{array}{r}\text { BRS projected } \\
\text { annual supply } \\
2005-09 \\
\text { (million } \mathrm{m}^{3} \text { p.a.) }\end{array}$ & $\begin{array}{r}\text { Excess supply } \\
\text { capacity } \\
\text { (million } \mathrm{m}^{3} \text { p.a.) }\end{array}$ & $\begin{array}{r}\% \text { of projected } \\
\text { annual supply not } \\
\text { logged in } 2006 / 07 \\
\text { (\%) }\end{array}$ \\
\hline Softwood sawlogs & $9.2^{\mathrm{a}}$ & 10.1 & 0.9 & 8.9 \\
\hline Softwood chiplogs \& other & 5.1 & 5.4 & 0.3 & 5.6 \\
\hline Total softwood & 14.3 & 15.5 & 1.2 & 7.7 \\
\hline Hardwood sawlogs & 0.158 & 0.224 & 0.07 & 31.3 \\
\hline Hardwood chiplogs & 3.9 & 4.6 & 0.7 & 15.2 \\
\hline Total hardwood & 4.0 & 4.8 & 0.8 & 16.7 \\
\hline
\end{tabular}

a. An estimated 0.27 million $\mathrm{m}^{3}$ of native cypress sawlog production was deducted from ABARE data. Source: ABARE 2008: 20; Parsons et al. 2007: 8 (BRS plantation wood-supply projections).

With surging plantation resources and subdued markets — both domestically for wood and globally for hardwood chips (discussed later in this paper) plantations have not 'complemented' or 'topped up' native forest-wood resources, as those in the native forest sector hoped. Rather, the new and highly efficient softwood plantation sawmillers have sent native forest sawn-timber production into permanent decline. The plantation-for-native-forest substitution process is about to be repeated in the hardwood-chip market.

\section{Wood processing}

The dominance of plantation forestry is also manifested in the wood processing sector.

Government statistics, by referring only to the generic 'forest products' or 'wood products', mask the plantation sector's substantial contribution to wood manufacturing investment, income and employment in Australia. ${ }^{3}$ The gaps in government reporting can, however, be filled using industry data and assumptions (Ajani 2008). Today, 80 per cent of the wood processed in Australia to make sawn timber, wood-based panels, pulp and paper comes from plantations (Table 2).

\footnotetext{
2 This static picture, however, masks the softwood sawmillers' desirable run down of the large softwood sawlog stockpile that had accumulated by the early 1990s (Ajani 2007: 64) and what appears to be the beginning of an undesirable stockpile in the hardwood estate.

${ }^{3}$ Whilst Federal Government statistics disaggregate almost all the wood Australia produces into distinct regimes - plantations (agriculture) and native forests (self-regenerating ecosystems) — processing industry data are not similarly disaggregated.
} 
Table 2: Estimated Australian production of wood and wood products and unprocessed wood exports by wood source - 2006/07

\begin{tabular}{|c|c|c|c|c|}
\hline & Unit & Plantation & Native forest & $\%$ plantation \\
\hline Wood production & $\begin{array}{l}\text { million } \mathrm{m}^{3} \\
\text { roundwood }^{\text {a }}\end{array}$ & 18.3 & 8.8 & 68 \\
\hline $\begin{array}{l}\text { Sawn timber \& } \\
\text { wood-based panels }\end{array}$ & $\begin{array}{l}\text { million } \mathrm{m}^{3} \text { finished } \\
\text { product }\end{array}$ & 5.6 & 1.3 & 81 \\
\hline $\begin{array}{l}\text { Wood for domestic pulp } \\
\text { production }(2004 / 05)\end{array}$ & $\begin{array}{l}\text { million } \mathrm{m}^{3} \\
\text { roundwood }\end{array}$ & 2.4 & 0.7 & 77 \\
\hline Other wood products & $\begin{array}{c}\text { million } \mathrm{m}^{3} \text { finished } \\
\text { product }\end{array}$ & 0.5 & 0.3 & 63 \\
\hline $\begin{array}{l}\text { Unprocessed wood - } \\
\text { chips \& logs }\end{array}$ & $\begin{array}{l}\text { million } \mathrm{m}^{3} \\
\text { roundwood }\end{array}$ & 7.2 & 5.7 & 56 \\
\hline
\end{tabular}

a. Roundwood here means the volume of wood in (round) log form required to make the product and therefore includes processing residues.

Source: Ajani 2008

\section{Sawn timber and wood-based panels}

It is native-forest sawmillers that have suffered the most from competition from the softwood plantations. Cheap native-forest logs could not counter the plantation sector's advantages of scale economies and new product development.

Figure 2: Plantation sawmillers meet most of Australia's sawn timber consumption

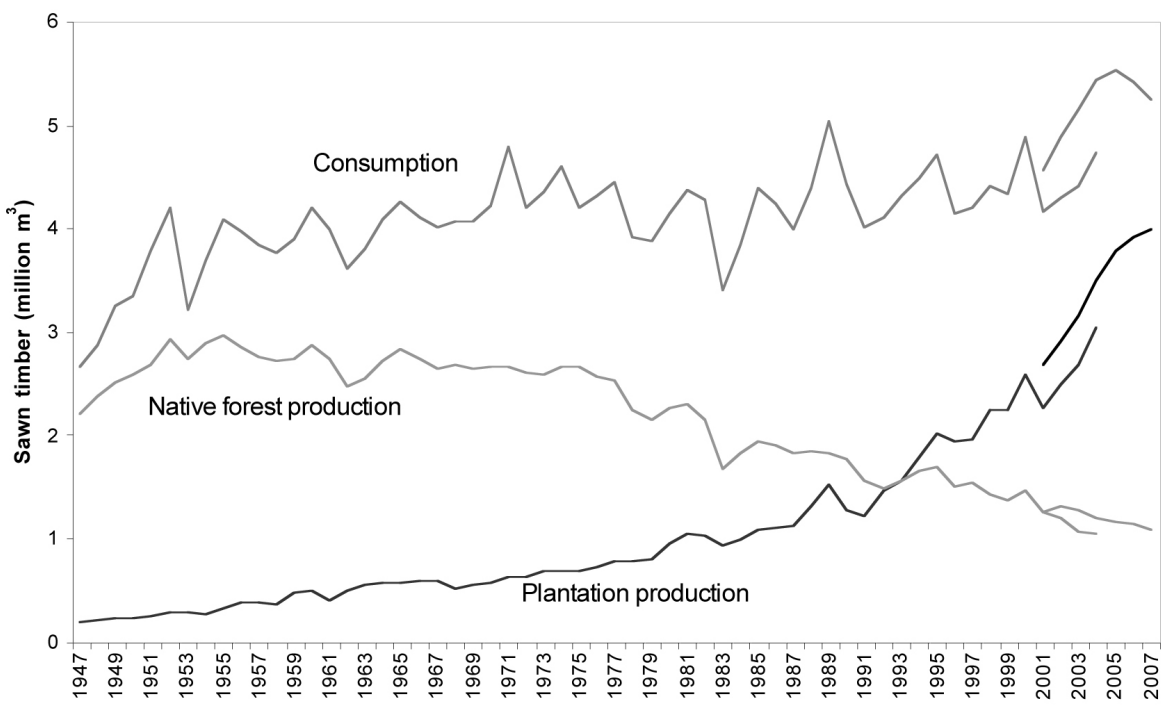

Source: Ajani 2007 (Figures 4.2 \& 5.3) and updated using ABARE Forest and Wood Products Statistics Note: ABARE data since 2000, using a changed methodology, are presented separately. Plantation production since 2001 includes a small volume of native forest cypress. 
Wood-based panels are rarely mentioned, despite being an Australian forestry-industry success story. ${ }^{4}$ Most forestry-industry analysis separates sawn timber from wood-based panels and then shines the spotlight on sawn timber. The public forest debate ignores wood-based panels. Yet, these panels compete against native forest and plantation sawn timber in many markets and, together with non-wood substitutes such as concrete and bricks, have contributed to the flattening in sawn-timber consumption in developed countries and lacklustre sawn-timber consumption in developing countries.

In the Australian forest debate, the plantation processors' achievements remain a largely untold story. Whilst the native-forest sawmillers attributed their demise to conservation reserves and environmentalists focus on unsustainable logging, the softwood-plantation processors concentrated on building market share largely through displacing native-forest sawn timber in the Australian market. Their output of sawn timber and wood-based panels has increased by 145 per cent since 1990 (Table 3). They achieved this by displacing Australian native forest sawn timber and imports whilst boosting net industry output. Today, Australia produces 65 per cent more sawn timber and wood-based panels than in 1990. In the big picture, the decline in native-forest sawmilling has occurred less because of native-forest protection and more in the wake of the expansion of plantation processing: an industry outcome government unwittingly set in place many decades ago when it financed an Australia-wide escalation in softwood planting.

\section{Table 3: Australian production of sawn timber and wood-based panels}

\section{(million $\mathrm{m}^{3}$ )}

\begin{tabular}{lrrr}
\hline & Year ending June 1990 & Year ending June 2007 & \% change \\
\hline Plantation & & & +206 \\
\hline Sawn timber & 1.27 & 3.89 & +70 \\
\hline Wood-based panels & 1.03 & 1.75 & +145 \\
\hline Total & 2.30 & 5.64 & \\
\hline & & & -33 \\
\hline Native forest & & 1.17 & -33 \\
\hline Sawn timber & 1.75 & 0.08 & -33 \\
\hline Wood-based panels & 0.12 & 1.25 & +65 \\
\hline Total & 1.87 & & 6.89 \\
\hline
\end{tabular}

Source: Ajani 2008; Ajani 2002 (following methodology as described in section 8)

${ }^{4}$ Wood-based panels, such as particleboard, medium-density fibreboard and plywood, are made by compressing and gluing particles or pieces of wood. They compete against sawn timber and non-wood products and, in Australia, are made primarily with plantation wood. 


\section{Pulp and paper}

The dominance of plantation forestry is also manifested in the pulp and paper sectors.

To see this, we need to appreciate that the Australian pulp-and-paper sector falls into four segments - packaging and industrial paper; printing and writing paper; newsprint; and household and sanitary paper (Table 4).

Table 4: Australian paper consumption and production - 2006/07

\begin{tabular}{lrrrrr}
\hline & $\begin{array}{r}\text { Consumption } \\
\text { (million tonnes) }\end{array}$ & $\begin{array}{c}\text { Production } \\
\text { (million tonnes) }\end{array}$ & $\begin{array}{r}\text { Imports (million } \\
\text { tonnes) }\end{array}$ & $\begin{array}{r}\text { Exports (million } \\
\text { tonnes) }\end{array}$ & $\begin{array}{r}\text { Net } \\
\text { self-sufficiency } \\
\text { (\%) }\end{array}$ \\
\hline Packaging \& industrial & 1.5 & 1.9 & 0.3 & 0.6 & 127 \\
\hline Printing \& writing & 1.7 & 0.7 & 1.2 & 0.1 & 41 \\
\hline Newsprint & 0.7 & 0.4 & 0.3 & 0.0 & 57 \\
\hline Household \& sanitary & 0.3 & 0.2 & 0.1 & 0.03 & 67 \\
\hline Total & 4.2 & 3.2 & 1.8 & 0.8 & 76 \\
\hline
\end{tabular}

Source: ABARE 2008. Figures unadjusted after rounding

Government attention to printing and writing papers is analogous to the attention still focused on native-forest sawmilling. In fact, packaging papers dominate Australian paper production (60 per cent in volume terms), as they do globally. Since 1980, growth in Australia's paper industry has concentrated entirely on packaging and industrial, and printing and writing papers, both growing at a strong average rate of 4 per cent per annum over this period (Figure 3). Whilst packaging and industrial-paper production has faltered since 2004, printing and writing-paper production continues on its long-term upward trend.

\section{Figure 3: Paper production - Australia}

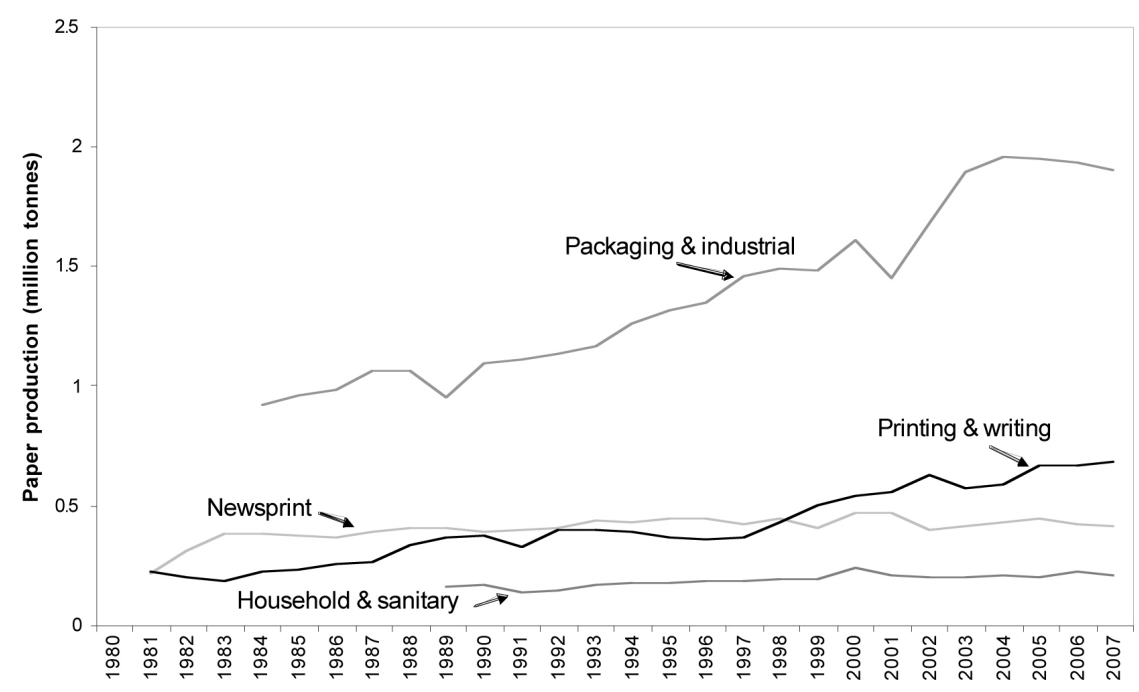

Source: ABARE Australian Commodity Statistics. 
Despite the dominance and export success of packaging papers, printing and writing papers very much shape the public perception of Australia's paper industry. Though this sector attracts most public attention, it is, in important ways, the odd man out in Australia's paper industry. Because Australia's monopoly producer of printing-and-writing paper (PaperlinX, formerly Amcor) uses little recycled fibre to make these papers (Table 5); wood is the main feedstock. For these papers, many producers prefer short-fibred hardwoods to long-fibred softwood (Higgens 1991). In Australia, native forests do supply plentiful and cheap short-fibred hardwood. But manufacturers of the other three paper-industry segments (packaging and industrial; newsprint; and household and sanitary) use mostly softwood (and so, in the Australian context, plantations) in their wood pulping to reap the strength benefits of longer fibres. Thus, as a whole, Australia's paper producers rely on native forests for only 9 per cent of their production (using a wood-to-paper conversion of 3:1) (Table 5).

Table 5: Australian paper production and its feedstock - 2004/05

\begin{tabular}{lrrrrrr}
\hline Product & $\begin{array}{r}\text { Production } \\
\text { (000 tonnes) }\end{array}$ & $\begin{array}{r}\text { Per cent } \\
\text { made using } \\
\text { recycled } \\
\text { fibre } \\
(\%)\end{array}$ & $\begin{array}{r}\text { Per cent } \\
\text { made using } \\
\text { new wood } \\
\text { fibre \& } \\
\text { additives } \\
(\%)\end{array}$ & $\begin{array}{r}\text { Softwood } \\
\text { plantation } \\
\text { (00) green } \\
\text { tonnes) }\end{array}$ & $\begin{array}{r}\text { Hardwood Native forest } \\
\text { plantation } \\
\text { wood input } \\
\text { (000 green } \\
\text { tonnes) }\end{array}$ & $\begin{array}{r}\text { (000 green } \\
\text { tonnes) }\end{array}$ \\
\hline Packaging \& industrial & 1885 & 70 & 30 & na & na & na \\
\hline Printing \& writing & 604 & 4 & 96 & na & na & na \\
\hline Newsprint & 423 & 32 & 68 & na & na & na \\
\hline Household \& sanitary & 157 & 3 & 97 & na & na & na \\
\hline Total & 3069 & 48 & 52 & 2156 & 303 & 788 \\
\hline
\end{tabular}

Source: Australian Plantation Products and Paper Industry Council (AP3) 2005

Note: Statistics are compiled from information collected from Australia's six major paper producers and include imported pulp (20 per cent of pulp input) and imported recycled paper ( 4 per cent of recycled fibre input).

Increased paper recycling and increased softwood-pulping capacity have been the mainstays for Australia's growing paper production. Since 1980, three new softwood-plantation pulpmills have been constructed in Australia: at Albury (1981), Maryvale (1984) and Tumut (2001). All three mills were constructed primarily for the domestic paper market, with output absorbed largely by growth in domestic paper consumption and import replacement.

Gunns' proposed Tasmanian hardwood pulpmill breaks this pattern of domestic orientation. With PaperlinX having effectively stitched-up the domestic market through its monopoly production of printing-and-writing paper and controlling interests in imports of these paper grades, companies investing in new hardwood pulpmills are effectively forced into the roller-coaster global pulp market. In economic downturns, integrated pulp-and-paper producers scale back their paper production and offload their surplus pulp at cost price (Ajani 2007: 301-3). Survival for export-oriented pulpmills demands highly competitive projects from start-up. Gunns' proposed Tasmanian pulpmill may 
not make the grade, even with the commercial benefits of a low-priced public native-forest resource and government subsidies on capital costs (Edwards 2008). Whilst resource conflicts have dominated Australia's pulpmill debate over the past two decades, Australia's concentrated printing-and-writing-paper sector and the nature of the global pulp-and-paper market also work against Australia securing a new hardwood pulpmill.

\section{Unprocessed wood exports}

The dominance of plantation forestry will soon extend to wood chips.

Half of Australia's wood production is exported as unprocessed chips and logs (Table 2). This forestry-wide statistic masks important differences in the industry structures built around plantations and native forests. The native-forest sector exports a considerably higher proportion of its log-cut as unprocessed chips and logs compared to the plantation sector (Table 2). In Australia's major public native-forest logging regions of Tasmania, East Gippsland and south-east NSW, woodchip exports now account for between 80 to 90 per cent of the log-cut (Ajani 2007: 278).

\section{Figure 4: Declining real prices for hardwood chip exports}

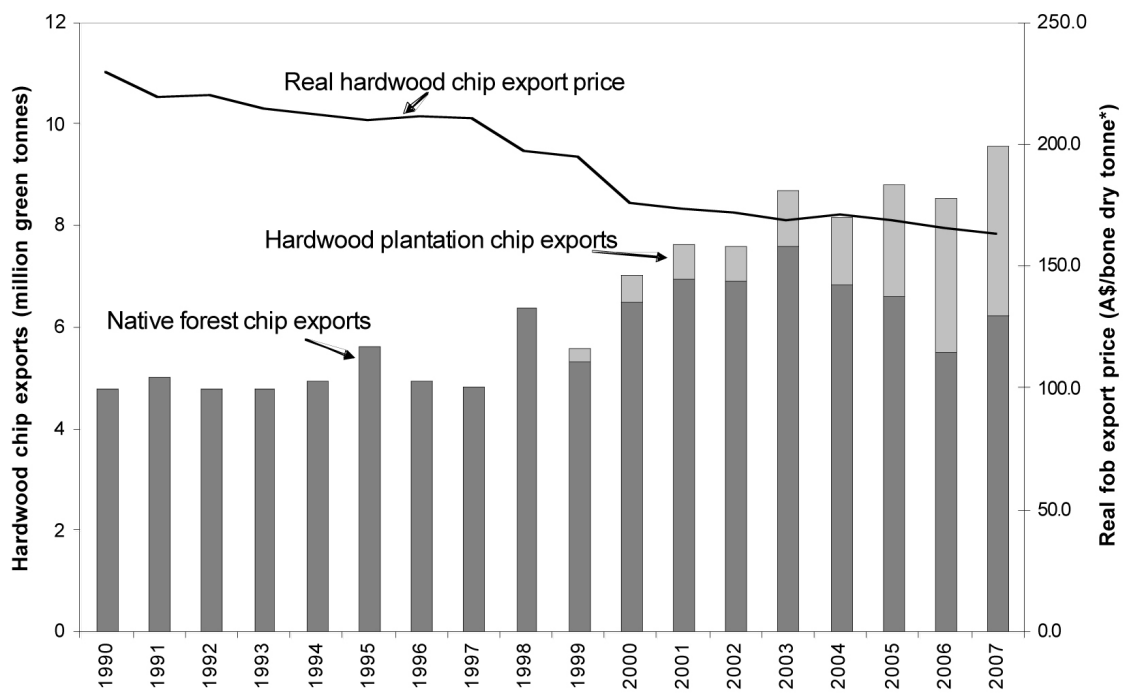

* Prices deflated using Australian CPI 2006/07 = 100.

Calculated using ABARE forestry statistics and Australian Plantation Products and Paper Industry Council (AP3) 2005.

In the immediate post-Regional Forest Agreements (RFA) era of abolished Commonwealth woodchip-export controls, native-forest woodchip exports increased by 44 per cent, from 4.8 million green tonnes in 1997 to 6.9 million green tonnes in 2001. With Japan's stagnant market (Japan Paper Association; Japan Tariff Association), chip exporters (then mostly native-forest-based) 
secured this 2 million tonne new trade by settling on an 18 per cent fall in real chip prices over the four years (Figure 4).

Woodchips from Australia's early managed-investment-scheme hardwood plantings are now coming on stream and substituting for native forest resources (Figure 4) in a continuing flat global market. Australia's hardwood plantation chiplog supply is poised to increase by 9 million green tonnes over the next two to three years (Figure 5). With little growth in global demand for hardwood chips, we can expect ongoing displacement of native-forest chips and, given the size of the additional plantation resources, continuing downward pressure on chip prices.

China may alleviate the market situation. Its industrial wood imports have increased by an average 19 per cent per annum over the 10 years ending 2006 and now account for a quarter of the global industrial wood trade (FAOSTAT 2008). Clearing Australia's hardwood-plantation chip resource through exports to China would require Australian exporters to lift their share of Chinese industrial wood imports from its current 2 per cent to 25 per cent within two to three years. This is a challenging task for trade negotiators, given China's buying-power capacity to drive prices down. Whilst China's wood imports surge, real import prices have declined by an average 6.8 per cent per annum over the decade ending 2006: in other words, halved (FAOSTAT unit import prices in US\$ deflated by US CPI).

\section{Figure 5: Australia's hardwood-chip glut}

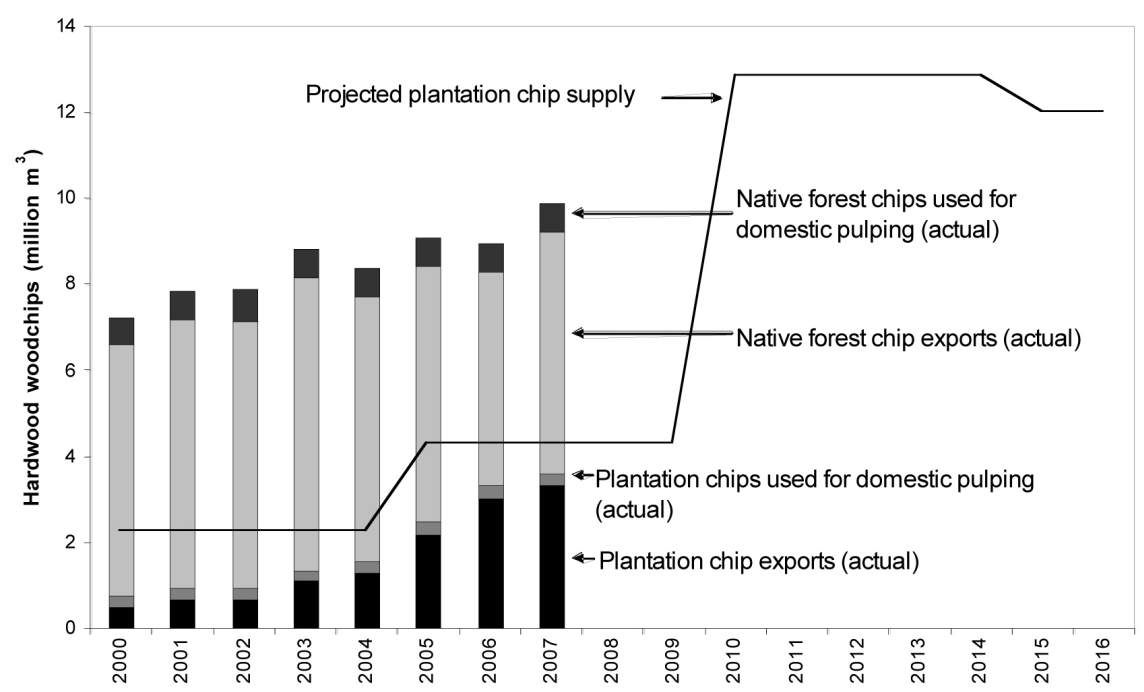

Source: Compiled using Parsons et al. 2007 (BRS plantation wood-supply projections); Ferguson et al. 2002; ABARE Forest and Wood Products Statistics; Australian Plantation Products and Paper Industry Council (A3P) 2005 


\section{Australia's current forest policy issues}

To summarise: today, plantations supply 80 per cent of the Australian wood-processing industry's raw material (Table 2). With full uptake of Australia's plantation resources, processors can meet virtually all our wood needs without relying on native forests or imports. 'Virtually' is a key word used to cover at least 95 per cent of Australia's wood needs; namely, all paper grades, wood-based panels and most sawn timber. In these commodity markets, hardwood and softwood plantation products substitute readily for native-forest products (Ajani 2004). Substitution is less perfect for the relatively small amount of high-appearance-hardwood sawn timber produced in Australia. Supply options for these products are discussed below.

Whilst plantations underpin the Australian wood-products industry's enhanced productivity and have brought significant investment, income and employment to regional Australia, the ecological benefits arising from Australia's shift to plantation-wood products lie largely unrealised. This is because governments facilitated new markets for native-forest wood - namely, woodchip exports - rather than securing significantly more conservation of biodiversity, protection of water catchments and mitigation of climate change.

Australia is poised for a second plantation-resources boom (Figure 1) as large areas of private-sector hardwood plantations come on stream. Most of the logs are destined for the export woodchip market and, as perfect substitutes, will compete against native-forest chip exports, now the dominant outlet for native-forest logging. The issues facing government policymakers in these deliberations narrow to three groupings.

\section{Federal Government disengagement}

Despite the forestry industry's high and increasing plantation dependence that opens pragmatic conservation opportunities, the two major parties appear spooked by the public forest conflict. They judge that political safety lies in their mutual disengagement from native-forest conservation, while backing forestry and wood growing. Critical analysis is absent. The major parties maintain policy settings that drive ongoing plantation investment, but make no policy connection between Australia's burgeoning plantation resources and the potential for protecting native forests. Reading the parliamentary debates reveals a stronghold of forestry misperceptions (Ajani 2007: 218-42) justifying this behaviour.

As the decade-old claim that Australia's plantation resources are not able to meet the nation's wood needs becomes untenable, two other claims remain forcefully asserted. The first is that Australia must continue logging native forests at current rates to supply the sawlogs for high-appearance sawn timber that (softwood) plantations cannot. Woodchip exports are then presented as a 
benign and sensible use of waste as a secondary business. So the decisive question is: how much of Australia's native forest log-cut is used to make high-appearance sawn timber, and how much of this product sells on its appearance (rather than its price); how much is sold as speciality native-forest hardwood products, rather than commodities with an array of substitutes?

ABARE's newly conducted national sawmill survey (ABARE 2008: 8-14) tagged only 36 per cent of hardwood sawn timber as appearance-grade (in volume terms, more softwood-plantation sawn timber is sold as appearance-grade). If, based on Neufeld (2000: 127) we allow for half of ABARE-reported appearance native-forest sawn timber being purchased on its appearance or aesthetic qualities, then perhaps around 2 per cent of Australia's native-forest log-cut currently finds its way into these appearance products (in roundwood equivalent terms, around 0.5 million $\mathrm{m}^{3}$ of sawlogs per annum out of an annual native-forest log-cut of 8.8 million $\mathrm{m}^{3}$ ). Whilst governments and major opposition parties grasp at the ' 2 per cent excuse' for rejecting forest conservation and overhauling an economically incoherent forestry-industry policy, Australia's plantation resources keep soaring (Figure 1).

Various interlinked and time-dependent options exist for sourcing 0.5 million $\mathrm{m}^{3}$ of hardwood sawlogs per annum for high-appearance uses. Government resource projections indicate that hardwood plantations in the ground now will deliver increasing volumes of hardwood sawlogs, from 0.2 million $\mathrm{m}^{3}$ per annum over 2005-09 to 0.4 million $\mathrm{m}^{3}$ per annum over 2010-14 to 0.6 million $\mathrm{m}^{3}$ per annum over 2015-19 and rising to 1.1 million $\mathrm{m}^{3}$ per annum over 2020-24 (Parsons et al. 2007: 8). If these volumes or their quality are inadequate, the resource could be topped up temporarily using native forests (selectively logged, with forest ecologists setting the regulations) or improving recycling whilst more plantings for high-quality sawn timber are established. Given the small log volumes involved, finding the short-term, top-up logs in native forests at minimum ecological cost should not be an onerous or high-conflict task.

The high dependency of 'timber' workers on industry's access to native forests is the second claim that restricts new forest policy. There are no government statistics to prove, or disprove, this claim. However, we can establish a reasonable feel for the employment reality. Processing generates most forestry-industry jobs, and here plantations and paper recycling dominate: 80 per cent of Australia's sawn timber and wood panels are plantation-based and 90 per cent of our paper is made from recycled fibre, plantation pulp or other non-native-forest feedstock (Tables 2 \& 5). Plantations also dominate wood supply. Plantation-wood growing, processing and exporting, together with paper recycling, probably generates between 75 to 80 per cent of the industry's employment, allowing for higher labour productivity in the plantation sector. 
The Commonwealth was instrumental in creating Australia's plantation industry and employment reality. However, it has let misperceptions - notably around appearance sawn timber and jobs - silence its plantation legacy and be the excuse for not driving a fundamental overhaul of forest policy to address the interlinked imperatives of protecting biodiversity and water catchments and mitigating the effects of climate change.

\section{Managed investment schemes, tax deductibility and future plantation wood supply}

Who invests in trees is largely about who is prepared to take the risk of investing in a product that generates profits at the mid to lower end - like most other agricultural raw materials - and where income follows between one to three decades after the initial investment. Few wood processors or unprocessed-wood exporters have plantation assets and most that did have divested. In the past the public, through State and Commonwealth funding, bore most of the softwood-plantation risk. Today, managed investment schemes are the dominant vehicle for tree planting. But the risk-takers are still the public, whose purse has provided around $\$ 2$ billion in tax deductions to thousands of tax-minimising, passive, plantation investors. In June 2008, the Australian Parliament enacted legislation to broaden the tax provisions for growers with a new tax deduction for tree planting for carbon sequestration (Tax Laws Amendment (2008 Measures No. 2) Act 2008) — without ruling out their future logging, which would add even more to the wood supply and remove most of the benefits of carbon sequestration.

While planting continues apace, prospectus expectations of market opportunities for woodchips have not yet materialised. Most of the now-maturing hardwood-plantation resource competes against low-priced native-forest chiplogs (Ajani 2007: 265) in the stagnant global hardwood-chip market. Domestic processing opportunities, namely pulp and paper mills and wood panel plants, lie dormant, hindered by high plantation stumpage prices. These prices, together with arguably high assumed wood yields, offset the high investment cost averaging \$9300 per hectare in 2001 (Lonsec Agribusiness Research 2001), which generates a bigger tax deduction and bigger up-front profits to the prospectus company for each hectare planted. The all-up actual cost of buying a hectare of land, planting it with trees and managing them over the rotation is around $\$ 4500$ a hectare (Ajani 2007: 255). From experience, we know that investment driven by the demand for tax minimisation, and not market realities, is associated with collapse.

The optimal allocation of water and agricultural land for food and fibre production requires final product demand to set the rate of new planting, not artificially driven plantation investment or incentives for inefficient 'carbon sink forests'. Evidence of market failure justifying these plantation assistance 
measures is not compelling. There appears to be no evidence of capital-market failure resulting in plantation investors not being able to access finance. Higher interest rates may be attached to finance for planting, but this is normal for any long-term and therefore more risky investment. Similarly, evidence appears to be lacking of market failure justifying government intervention in plantation wood growing. Competition in the Australian plantation industry has increased, with increased private-sector investment breaking up state government dominance and it is difficult to claim information asymmetry between wood buyers and sellers. Other possible public goods associated with plantations, such as landcare and water-catchment benefits, should be investigated on a site-specific basis to justify government intervention. Plantation water use has emerged as a major disbenefit in many catchments.

Finally, as discussed in the next section, the carbon-sequestration public-good argument of plantations falls short when assessed against other land-use options.

\section{Climate change}

The Federal Government has elevated climate change to a high policy priority. Reducing emissions from the use of fossil fuels attracts much of the attention, and rightly so. However, emissions from forestry account for about 17.5 per cent of global emissions (Intergovernmental Panel on Climate Change 2007). Therefore, changes to land use and management in native forests hold opportunities for significant immediate and prospective reductions in $\mathrm{CO}_{2}$ emissions, along with the potential for further sequestration over coming decades. Australia's plantation reality makes the realisation of these native-forest opportunities appealing, both economically and environmentally.

Once again, gaps in data frustrate policymaking. The Australian Greenhouse Office (AGO) generates valuable information and analysis in many areas but much greater attention is required on the native-forest front. Crucially, the AGO does not report the annual emissions from native-forest logging: emissions are reported net of native-forest sequestration. Using AGO data, Blakers (2008: 4) estimates that logging native forests generates an estimated 38 million tonnes of $\mathrm{CO}_{2}$-e (carbon dioxide equivalent) annually, equivalent to 7 per cent of Australia's total net greenhouse-gas emissions. Combined with the estimated 11 to 13 per cent contribution of native-forest clearing to Australia's net emissions over 2005 and 2006 (Australian National Greenhouse Accounts), deforestation and native forest degradation from logging accounts for emissions equivalent to 20 per cent of Australia's annual net greenhouse-gas emissions.

Existing high-density carbon stores, especially mature native forests, cannot be substituted: there is not enough land or water to enable regrowing vegetation to recapture the emitted carbon in a policy-relevant timeframe. From a climate-mitigation perspective, significant emissions can be avoided by giving 
priority to protecting the stores of carbon in existing native vegetation, especially mature and old forests with their large carbon-dense trees (Roxburgh et al. 2006), by removing them from wood production and allowing them to regrow. As demonstrated in the first sections of the paper, it is now possible for existing plantation resources to substitute for virtually all the forgone wood.

Scientific investigation into the carbon stocks and storage potential of Australia's native forests is now coming to fruition. Mackey et al. (2008) investigated the carbon-carrying capacity of 14.5 million hectares of south-east Australian eucalypt native forests (Southern Queensland, NSW, Victoria and Tasmania), about half of Australia's remaining eucalypt native forests. They estimated their average total carbon-carrying capacity to be 640 tonnes of carbon per hectare. Given this, they estimated that these forests in their natural condition have the potential to store some 33 billion tonnes of $\mathrm{CO}_{2}-\mathrm{e} .^{5}$ About 56 per cent of the study area has been logged and is therefore below carbon-carrying capacity. Given that previous studies have suggested that carbon stocks in logged forests can be around 40 per cent below their carbon-carrying capacity (Roxburgh et al. 2006), the carbon sequestration potential of these forests could be as much as 7.5 billion tonnes of $\mathrm{CO}_{2}$-e. While further analyses are needed, this estimate is sufficient to highlight the order of magnitude impact on Australia's carbon accounts if logging was halted in these south-east Australian native forests, thereby enabling them to regrow their carbon stocks towards their natural carbon-carrying capacity.

Using the equivalence factor developed by Costa \& Wilson (2000) to facilitate the assessment of sequestration-based land-use projects, the sequestration potential of halting logging in Australia's south-east native forests is estimated to be equivalent to avoiding emissions of 136 million tonnes of $\mathrm{CO}_{2}$-e per year for the next 100 years (Mackey et al. 2008: 38): an annual rate of emissions equivalent to 24 per cent of Australia's net greenhouse-gas emissions from all sectors in 2006.

The Australian Government adopts the Kyoto Protocol carbon accounting framework in its Carbon Pollution Reduction Scheme Green Paper (2008). This framework ignores native-forest logging emissions and sequestration opportunities from shifting wood production from carbon-dense native forests to less carbon-dense plantations. The Government proposes not to include native forests in Australia's emissions trading scheme. Although not advanced in the Government's Green Paper, two arguments support this decision. First, because an emissions trading system works on flows, it is difficult to provide a continuing income stream for the permanent protection of the stocks of carbon in native forests. Secondly, because an emissions trading system treats carbon as a

\footnotetext{
${ }^{5}$ Australia emitted in the region of 576 million tonnes of $\mathrm{CO}_{2}$-e in 2006. (www.climatechange.gov.au)
} 
homogeneous commodity, it does not distinguish between carbon stored in a tree crop and carbon stored in a significantly more resilient bio-diverse native-forest ecosystem; nor does it recognise the longer residency time of carbon in the various pools of a native forest, the age of the forest, and therefore the time needed to recover $\mathrm{CO}_{2}$ emitted from degradation of the carbon stores by logging.

However, given the significance of native forests in Australia's carbon story, excluding them from our climate-change challenge is untenable. Exclusion would increase the cost burden on other greenhouse-gas polluting companies forced to pull their weight. It would also advantage companies processing native-forest wood into sawn timber, pulp, paper and other wood products, including biofuels, since neither their associated biomass carbon emissions nor the lost native-forest sequestration opportunities would be costed.

Incorporating native forests in Australia's climate-change challenge is best done outside the emissions trading system and linked to a much-needed review of forestry-industry policy to capitalise on Australia's plantation resources. From a climate-change perspective, the task is to secure funding for the permanent protection of native forests (and other self-regenerating natural terrestrial ecosystems) for carbon storage, together with water and biodiversity conservation. A government body tasked with this job staffed by people knowledgeable in this field could set the priorities and build the strategies. Its funding could be multi-sourced (including redirection of government taxation support for 'carbon sink forests' and a proportion of government funding for land management), setting aside a fixed part of revenue from emissions-trading permit sales or trades and private/voluntary contributions.

In its Green Paper, the Government proposes that plantations established since 1990 on previously cleared land - and therefore in accordance with the Kyoto Protocol - be included in Australia's emissions trading scheme as an opportunity to generate offset credits within the forestry industry, on a voluntary basis (Australian Government 2008: 132). Relative to protecting native forests - from deforestation and degradation — and restoring native vegetation ecosystems, plantations are a high-cost and high-risk $\mathrm{CO}_{2}$ mitigation option. For plantations to achieve the same sequestration benefit as halting logging in the native-forest study area investigated by Mackey et al. (2008: 38) requires a conservatively estimated additional 4 million hectares of plantations, at a cost of $\$ 18$ billion ( $\$ 35$ billion if established through managed investment schemes). ${ }^{6}$ Plantations, being production systems, lose most of their stored carbon on harvest or in short-lived products. Not being self-sustaining agricultural systems, they also embody higher management costs (which also generate emissions) and higher

\footnotetext{
${ }^{6}$ Author's calculation method and sources available on request.
} 
risks associated with disease, drought, wind damage and fire (see, for example, Munishi \& Chamshama 1994; Perera 1989). Relative to permanently protected, self-regenerating natural ecosystems, plantations are an inefficient carbon-sequestration system. However, because of this inefficiency, plantations are a significantly more climate-friendly way of meeting our wood needs than logging native forests. The $\mathrm{CO}_{2}$ recapture time for plantation wood may be from one to a few decades, depending on the age of the plantation when logged, while the recapture time for native-forest wood is many decades longer, again depending on the age when logged.

By including plantations in its proposed emissions trading scheme - but not native forests - the Government will create counter-productive market signals for climate-change mitigation and forestry-industry productivity. Perhaps unwittingly, it proposes to reward investment in an inferior sequestration strategy (plantations) and handicap the economically superior plantation-processing industry relative to its native-forest-based competitors whose emissions will not be costed. The result may be perverse in two ways. First, emissions are likely to be higher overall, as logging is redirected into native forests where emissions liabilities do not apply. Secondly, wood supply for plantation processors may become too expensive as wood-growing competes with carbon-growing and the value of carbon rises (Wood \& Ajani 2008).

This outcome could be avoided with a structural adjustment package to complete the forestry industry's plantation transition - particularly in the hardwood-chip sector - combined with directing the task of biomass sequestration to self-regenerating natural ecosystems managed under a new institution, as discussed earlier. In this policy frame, wood supply remains the objective of plantation investment. With fossil fuels covered in an emissions trading scheme and carbon sequestered in plantation biomass cancelling out emissions over a rotation, the plantation industry has grounds for arguing its raw material be excluded from emissions trading. If granted, the associated compliance costs evaporate.

\section{Concluding comments}

Being perfect substitutes for native-forest chips, Australia's maturing hardwood plantations present a major opportunity for mitigating climate change. This opportunity will not be realised with business-as-usual forest-policy frames and policy information, which are steering Australia to perverse outcomes favouring investment in an inferior carbon-sequestration strategy and handicapping the economically superior plantation-processing industry.

\section{References}

ABARE 2008, Australian Forest and Wood Products Statistics September and December Quarters 2007, ABARE. 
Ajani (formerly Clark), J. 2002, 'Australian production of wood and wood products in 1989/90 disaggregated by wood source', unpublished paper, Fenner School of Environment and Society, The Australian National University.

Ajani (formerly Clark), J. 2004, 'Forest policy for sustainable commodity wood production: an examination drawing on the Australian experience', Ecological Economics 50: 219-32.

Ajani, J. 2007, The Forest Wars, MUP.

Ajani, J. 2008, 'Australian production of wood and wood products in 2006/07 disaggregated by wood source', unpublished paper, Fenner School of Environment and Society, The Australian National University.

Australian Government 2008, Carbon Pollution Reduction Scheme Green Paper at: <www.climatechange.gov.au>

Australian Plantation Products and Paper Industry Council (A3P) 2005, 'Australian paper industry statistics 2004-05'.

Blakers, M. 2008, 'Comments on Garnaut Climate Change Review: Issues Paper 1 Land-use-Agriculture and Forestry', submission to the Garnaut Climate Change Review, Green Institute.

Costa, P. M. and Wilson, C. 2000, 'An equivalence factor between $\mathrm{CO}_{2}$ avoided emissions and sequestration - description and application in forestry', Mitigation and Adaptation Strategies for Global Change 5: 51-60.

Edwards, N. 2008, 'Gunns Ltd: Mill competitiveness falls while government subsidies rise' at: naomiGNS_April_2008_Naomi_Edwards.pdf

FAOSTAT 2008, The Food and Agricultural Organisation of the United Nations forestry data base <http://faostat.fao.org/site/381/default.aspx $>$ last viewed August 2008.

Ferguson, I., Fox, J., Baker, T., Stackpole, D. and Wild, I. 2002, Plantations of Australia - Wood Availability 2001-2044, Bureau of Rural Sciences.

Garnaut Climate Change Review 2008, Draft Report at: $<$ http://www.garnautreview.org.au/CA25734E0016A131/pages/draft-report>

Higgens, H. G., 1991, 'An assessment of the extent to which hardwood and softwood can be interchanged in pulp and paper manufacture', Resource Assessment Commission, Forest and Timber Inquiry Consultancy Series.

Intergovernmental Panel on Climate Change 2007, The Fourth Assessment Report Climate Change 2007: Synthesis Report, Intergovernmental Panel on Climate Change at: <http://www.ipcc.ch/>

Japan Paper Association, Pulpwood Handbook, various editions (I thank Ian Penna for making this data available.) 
Japan Tariff Association, Japan Imports and Exports various editions (I thank Ian Penna for making this data available).

Lonsec Agribusiness Research 2001, 'Comparison of similar eucalyptus pulpwood projects', Lonsdale Securities.

Mackey, B. G., Keith, H., Berry, S. and Lindenmayer, D. B. 2008, Green Carbon: The Role of Natural Forests in Carbon Storage, The Australian National University, E PRESS.

Munishi, P. K. T. and Chamshama, S. A. O. 1994, 'A study of wind damage on Pinus patula stands in Southern Tanzania', Forest Ecology and Management 63: 13-21.

Neufeld, B. 2000, 'Sawn Timber in Australia 2000-2015; Market Opportunities, Strategies and Prospects for Trade and Investment', BIS Shrapnel Forestry Group Pty Ltd.

Parsons, M., Frakes, I. and Gavran, M. 2007, 'Australia's Plantation Log Supply 2005-2049', Bureau of Rural Sciences.

Perera, A. H. 1989, 'Post-fire recovery of 10-year old Pinus caribaea var. hondurensis in a hilly watershed in Sri Lanka', Forest Ecology and Management 28: 309-13.

Roxburgh, S. H., Wood, S. W., Mackey, B. G., Woldendorp, G. and Gibbons, P. 2006, 'Assessing the carbon sequestration potential of managed forests: a case study from temperate Australia', Journal of Applied Ecology 43: 1149-59.

Wood, P. J. and Ajani, J. 2008, Submission in response to the Australian Government Carbon Pollution Reduction Scheme Green Paper. 


\title{
Righting Australia's Vertical Fiscal Imbalance: Transferring Public Hospital Funding as an Option for Reform
}

\author{
Richard Eccleston ${ }^{1}$
}

\begin{abstract}
Vertical Fiscal Imbalance (VFI) is the root cause of intergovernmental conflict in the Australian federation, and un-remedied will limit the dividends of any revitalised Council of Australian Governments. The paper argues the while the GST has been an effective growth tax, it has exacerbated Australia's VFI and is unlikely to yield sufficient revenues to meet the expenditure pressures confronting the States. The paper suggests that transferring the funding of public hospitals to the Commonwealth will enhance the sustainability of State public finances and reduce the VFI.
\end{abstract}

\section{Introduction}

Reforming Australian federalism has become a clear priority for the Rudd Government. While a more negotiated and consensual style of federalism has the potential to deliver significant dividends, this article argues that intergovernmental relations in Australia will remain prone to conflict as long as the States remain financially dependent on the Commonwealth. Given this premise, the paper examines the extent of the vertical fiscal imbalance (VFI) in the Australian federation and whether the States have access to, and control over, sufficient revenues to deliver the services and infrastructure for which they are constitutionally responsible. The article throws some light on these issues by evaluating whether the post-GST Intergovernmental Agreement (IGA) of 1999 has enhanced the State's fiscal and budgetary capacity. Having provided an overview of developments in federal financial relations, the second half of the article assesses the implications of a federal takeover of public hospital funding, and concludes in favour of such a takeover.

\section{The 1998 GST Agreement and its aftermath}

The most surprising aspect of the Howard Government's 1998 GST (A New Tax System or ANTS) package was the fact that all GST revenue was to be allocated to the States in lieu of existing Revenue Replacement Grants (introduced after

\footnotetext{
1 The School of Government, the University of Tasmania, Richard.Eccleston@utas.edu.au. I would like to thank Agenda's editor and two anonymous referees for their detailed comments on an earlier draft of this article, as well as feedback from various colleagues in The School of Government of the University of Tasmania. The usual caveats apply. The analysis presented in this article served as the basis for an invited submission to the Senate Select Committee on State Government Financial Management.
} 
the $1997 \mathrm{Ha}$ Case), general Financial Assistance Grants and a host of other indirect State taxes (Eccleston 2004: 137; Hamill 2006: ch. 5). In many ways, this revenue-sharing strategy was a political masterstroke. The prospects of accessing a growth tax ensured the support of State Premiers. Moreover, the Intergovernmental Agreement (IGA) and the commitment therein that the proposed GST could only be altered with the unanimous support of both State and Federal Governments reassured voters that the GST rate would not subsequently be increased (Costello 1998). Yet, in terms of federalism, the most significant aspect of the ANTS package and the subsequent IGA was that it promised to put State finances on a more secure footing. This point was made by the Treasurer, Peter Costello, when he confidently predicted that 'The GST will provide the States and Territories with a secure source of revenue that grows as the economy grows to secure funding for essential services, such as schools, hospitals and roads' (as quoted in Hamill 2006: 126).

In many ways, the GST has lived up to the Howard Government's claims as GST revenues distributed to the States have risen by an average of 8.9 per cent per annum in nominal terms over the seven years since its introduction (Table 1). In fact, buoyant economic conditions and strong domestic consumption over the period have resulted in GST revenues exceeding predictions made when the tax was first proposed. For example, GST revenue in 2007-08 alone is projected to be 7.6 per cent higher than forecast under the IGA (Commonwealth of Australia 2007).

However, this aggregate data obscures a number of subtle, yet significant, impacts which the IGA has had on intergovernmental financial relations. The GST may, as Treasurer Costello promised, have provided a secure source of revenue for the States, but this does not necessarily mean that the State's funding base is adequate or that the IGA has necessarily enhanced the State's fiscal capacity, or their ability to control their own taxing and spending priorities (Hamill 2006: 75).

Table 1: Growth in GST to the States 2000-2007

\begin{tabular}{lccccccc}
\hline 2000-01 & $\mathbf{2 0 0 6 - 0 7}$ & Increase \$ & Increase \% & $\begin{array}{c}\text { Annual Avg. } \\
\text { Increase \% }\end{array}$ & $\begin{array}{c}\text { GSP } \\
\text { Avg. Annual } \\
\text { Increase \% }\end{array}$ & $\begin{array}{c}\text { State GST } \\
\text { 'windfall' }\end{array}$ \\
\hline NSW & $\mathbf{7 2 5 7 . 6 0}$ & 10937.5 & 3679.90 & 50.7 & 7.2 & 6.8 & $+0.4 \%$ \\
VIC & 5099.30 & 8588.0 & 3488.70 & 68.4 & 9.8 & 6.5 & $+3.3 \%$ \\
QLD & 4658.20 & 8092.2 & 3434 & 73.7 & 10.5 & 7.8 & $+2.7 \%$ \\
WA & 2374.60 & 3968.1 & 1593.50 & 67.1 & 9.6 & 14.5 & $-4.9 \%$ \\
SA & 2278.90 & 3604.9 & 1326 & 58.2 & 8.3 & 5.5 & $+2.8 \%$ \\
TAS & 988.1 & 1567.6 & 579.5 & 58.6 & 8.4 & 10.3 & $-1.9 \%$ \\
ACT & 472.6 & 778.3 & 305.7 & 64.7 & 9.2 & 9.7 & $-0.5 \%$ \\
NT & 1225.60 & 2015.3 & 789.7 & 64.4 & 9.2 & 8.9 & $+0.3 \%$ \\
TOTAL & 24354.90 & 39551.90 & 15197.00 & 62.4 & 8.9 & 8.6 & $+0.3 \%$ \\
\hline
\end{tabular}

(Source: ABS 2007 - Cat. 5220) 
In 2004 Treasurer Costello claimed the GST had delivered a windfall to the States 'over and above previous funding arrangements' (Costello 2004). While it is hard to refute the fact that the GST has grown faster than anticipated, it is also easy to overstate the fiscal dividends it has delivered. Firstly, strong economic growth in recent years means that the swag of State taxes and duties which were replaced under the IGA would also have grown more quickly than forecast. Given this, it is slightly misleading to represent the growth in the GST tax base as being a windfall (Collins and Warren 2007). Indeed, it can be argued that Commonwealth actually appropriated a portion of this windfall when it unilaterally decided to phase out balancing payments to the States two years ahead of schedule (Hamill 2006: 174). Similarly, the growth in GST revenue to Western Australia, Tasmania and the ACT actually lagged behind the increase in Gross State Product over the period (Table 1).

Another way of benchmarking the performance of the GST tax base is to compare its relative performance to other federal taxes. As Figure 1 indicates, GST revenues have not grown as a percentage of total federal revenue over the period and, with the exception of the economic slowdown of 2001-02, federal income taxes (despite significant cuts to personal income rates over the period) have tended to increase more rapidly than GST revenue. This finding is consistent with broader claims in the public finance literature that broad-based consumption taxes, such as the GST, deliver stable rather than spectacular revenue growth (Ebrill 2001). In short, the budgetary position of the States has improved over the period of the IGA, but not to the same extent as federal finances and, as a result, the Commonwealth is in a stronger position to fund high-cost public services such as public hospitals.

Figure 1: The growth in GST revenue relative to other federal taxes 2000-07

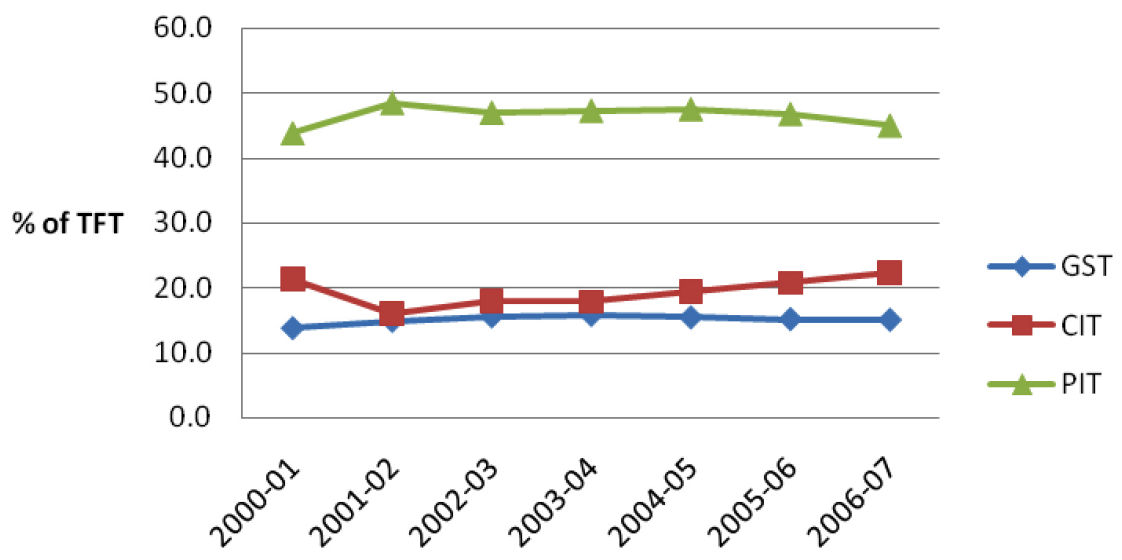

Fiscal Year

(Source: ABS 2007 - Cat. 5506) 
The second important consequence of the IGA is that it has eroded the fiscal capacity of the States because, with the IGA's abolition of various indirect taxes and duties and well as the Revenue Replacement Payments, the States are increasingly dependent on revenue sources over which they have no control. For example, in 1999-2000 (the year prior to the IGA) States raised 40 per cent of their total operating income from own-source taxes, whereas by 2005-06 this figure had fallen to 33 per cent (Hamill 2006: 150). The 2006 Ministerial Council agreement to abolish a second tranche of States taxes (with compensation) will erode the State tax base further (Commonwealth of Australia 2007).

\section{State Finances in the $21^{\text {st }}$ century}

The IGA granted the States access to an efficient growth tax in the form of the GST, which was to be administered by the Commonwealth. Given this context we would expect the States to gradually reduce their reliance on existing own-source taxes given both the electoral benefits of cutting taxes combined with widespread recognition that many of the remaining State taxes were administratively complex and economically inefficient (Smith 2007; Freebairn 2002). Yet an analysis of State taxation over the period clearly defies such predictions.

Table 2: Key trends in state taxation 2000-06

\begin{tabular}{lrrrrr}
\hline Column1 & 2000-01 & 2005-06 & Increase \$ & Increase \% & $\begin{array}{r}\text { Annual } \\
\text { Increase \% }\end{array}$ \\
\hline Gambling Machine Tax & 2071 & 2839 & 768 & $37.1 \%$ & $7.4 \%$ \\
Payroll tax & 9503 & 13087 & 3584 & $37.7 \%$ & $7.5 \%$ \\
Property tax & 7406 & 13784 & 6378 & $86.1 \%$ & $17.2 \%$ \\
Total State Rev & 32679 & 44235 & 11556 & $35.3 \%$ & $7.0 \%$ \\
\hline
\end{tabular}

(Source: ABS 2007 - Cat. 5220)

State taxation increased by over 35 per cent in nominal terms (or \$11.55 billion) over the period between mid-2000 and mid-2006. Of even greater significance is the specific composition of this increase and the fact that it was largely driven by the rapid growth in State property taxes on the back of a booming property market (particularly between 2000 and 2003). Over this period, revenues from land taxes and conveyancing charges on real-estate transactions increased by 28 per cent per annum. Even averaging this growth over the six years for which data is available, the housing boom contributed over 55 per cent of total State revenue growth, with payroll and gambling taxes accounting for most of the remainder. The problem for State public finances is that this property-tax windfall was the dividend of unsustainable housing boom, a reality borne out by the fact that such revenues have declined in real terms since 
2003-04 as real-estate prices have stabilised and the volume of property transactions has fallen (Productivity Commission 2004). ${ }^{2}$

Narrowly based taxes are inevitably inefficient and volatile. Periods of exceptional revenue growth, such as the States experienced during the early years of the decade, are a boon for public finances just so long as they are not committed to recurrent expenditure, and herein lies the budget challenge confronting the States. State governments were able to achieve modest cash surpluses (and retire State debt) at the height of the property boom. However, many States are now struggling to maintain a cash surplus as the growth in own-source revenues slows.

According to the latest Commonwealth Budget Papers (2008b), aggregate net State debt for the total non-financial public sector (which combines general government and public non-financial corporations) will increase from 1.1 per cent of GDP in 2005-06 to 5.7 per cent in 2009-10. These financial pressures will be compounded by the fact that total Commonwealth funding to the States (both GST revenue and Special Purpose Payments) will grow at a pedestrian 5.5 per cent over the forward estimates contained in the federal budget papers, significantly slower than in 8.2 per cent experienced in recent years (Commonwealth of Australia 2008b). When combined with unprecedented challenges in relation to health, education and infrastructure funding, it is not surprising that State Treasurers are once again trying to devise politically palatable ways of expanding their tax base and increasing revenue. ${ }^{3}$ In summary, the IGA increased total funding available to the States (budget capacity); however, this increase in funding has largely failed to keep pace with rising expenditure pressures. As a result, State governments have been forced to increase their reliance on their own-source taxation in addition to their growing transfers from the Commonwealth under the IGA. Regrettably, the tax base on which the States are becoming more reliant is even narrower and less efficient than that available prior to the introduction of the ANTS reforms (Freebairn 2002; Commonwealth of Australia 2008a).

\section{Expenditure Pressures: The public-hospital funding debate}

While it is not possible to provide a comprehensive analysis of the expenditure pressures currently confronting State governments, the next section of the paper

\footnotetext{
${ }^{2}$ While the national housing market experienced a temporary revival in 2007, preliminary data for the first quarter of 2008 suggests that higher interest rates are starting to bite. While prices of established dwellings remain steady, the fact that sales volumes have fallen by up to 30 per cent in some States does not bode well for property-tax revenue (ABS 2008).

3 The NSW Government's controversial proposal to privatise $\$ 21$ billion-worth of electricity assets has always been closely linked to the need to invest a $\$ 110$ billion in infrastructure of the next decade (Ferguson 2007).
} 
will provide insights into one of the main financial pressure points in the Australian federation; funding public hospitals.

A significant trend in Australian public finance in recent years has been for the States to fund a greater proportion of Australia's public-hospital system despite the fact that the States have the weakest revenue base. This is particularly significant given that health-care costs are growing faster than either GDP or revenue across the developed world. In the case of the Australian public-hospital system, according to the Australian Institute for Health and Welfare (AIHW) total funding has increased at 12 per cent per annum in nominal terms in the decade to 2005-06 (AIHW 2007). This is despite the fact that there has been increased utilisation of the private hospital system owing to the Commonwealth's private health insurance rebate (at a cost of $\$ 3$ billion per annum) and growing recognition that this level of funding is inadequate (AMA 2007). In short, the States have been shouldering a greater share of the public-hospital funding burden, a share which will have to increase significantly in order to improve the quality of key health services.

Figure 2: Funding sources for Australian public hospitals (current prices) 1995-96 to 2005-05

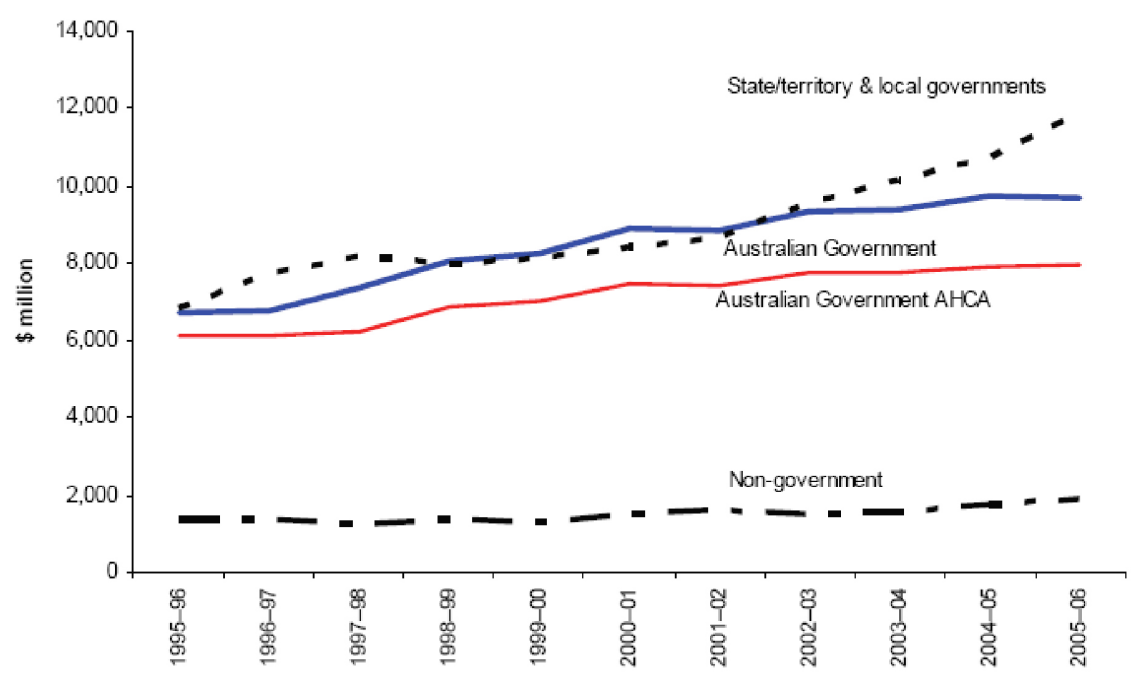

Source AIHW (2007: 55) Note: The upper line representing 'Australian Government' funding is inclusive of specific Australian Healthcare Agreement (AHCA) funding.

In absolute terms, State governments have increased public-hospital funding by between $\$ 1$ billion and $\$ 1.6$ billion per annum over the past three years (AIHW 2007: 55). Beyond this, State governments have argued that they require an additional $\$ 1.5$ billion per annum to adequately fund the public-hospital system (Queensland Government 2007). While this represents only one of the 
funding pressures confronting State governments, the growing revenue needs of public hospitals alone consumed 90 per cent of the GST growth dividend in the most recent year for which data is available. ${ }^{4}$ Given the fact that the growth in hospital costs (12 per cent per annum) has exceeded GST revenue growth (8.9 per cent per annum) over the past five years by 3 per cent per annum, it seems inevitable that despite the IGA the public finances of State governments are going to come under increasing pressure.

\section{Reforming federalism: Issues and objectives.}

This loss of fiscal independence has theoretical as well as policy and financial implications. Firstly, the centralisation of fiscal control implicit in the IGA runs contrary to the federalist ideal and the associated principle of financial subsidiarity, or the notion that taxing and spending decisions should be devolved to the level of government closest to citizens (Bird and Ebel 2006). Whilst there are ongoing debates about the relative political and economic merits of fiscal decentralisation (discussed below), it is clear that the IGA has reduced the potential for such devolution and inter-State variation in tax systems and rates.

The growing centralisation in Australian federalism under the IGA has also had a number of political and economic consequences. Arguably, the political authority of State governments has increasingly been constrained in key policy arenas such as education, health and water management, where they either require direct funding and/or cooperation from the Commonwealth. This has both eroded political accountability in Australia's federal system and has forced State governments to accede to Commonwealth demands in areas where States have traditionally had jurisdiction (for example, National Water Initiative; Mersey Hospital takeover).

Given that this paper is fundamentally concerned with intergovernmental financial relations it is important to briefly sketch established arguments concerning whether taxing powers should be centralised or devolved, and the related debate as to whether taxing powers and spending obligations ought to be aligned; the so-called vertical fiscal balance in a federal system.

\section{Arguments for fiscal decentralisation}

First and foremost is the idea that decentralisation will promote tax competition between States, acting as a constraint on revenue growth and providing incentives to improve the efficiency of State taxation. The so-called Tiebout hypothesis is popular with those on the right with an interest in constraining the size of the state while being criticised by those on the left who hold a more sanguine view of the state's ability to provide public goods (Tiebout 1956). A

\footnotetext{
4 Between 2004-05 and 2005-06, GST revenue growth to the States was \$1.83 billion. Over the same period, additional State funding to public hospitals was $\$ 1.63$ billion.
} 
related argument concerns the potential for innovation and interstate policy learning in a federal system. Thirdly, it is claimed that fiscal decentralisation can provide scope for State governments to tailor tax levels and the structure of State tax systems to meet specific regional needs.

\section{Arguments for fiscal centralisation}

There are also a number of arguments for fiscal centralisation. As national economies are exposed to increasing competitive pressures and commerce is increasingly conducted on a national and international scale, there have been growing calls for greater regulatory harmonisation (BCA 2007; Rudd 2007). In the tax arena it is argued that a national tax system reduces compliance costs for businesses operating across State boundaries as well as for consumers and employees who purchase goods and services or work interstate. Harmonisation also eliminates the potential for tax-related distortions caused when taxpayers try to exploit arbitrages between States. On the administrative front, there are also clear economies of scale when tax administration is managed by a national agency such as the ATO on a uniform national tax base.

\section{Vertical fiscal balance and financial accountability}

Another important theme in debates on fiscal federalism concerns the constitutional attribution of taxing powers and spending responsibilities in a federal system. Australia currently has the highest VFI of any federal state in the OECD (Twomey and Withers 2007: 37). There exists a consensus that the delivery of public services is both more efficient and transparent when there is a balance of taxing and spending powers within a federation (Mathews and Grewal 1997; Fitzgerald 1998; World Bank 2000:117; Row and Duhs 2001: 61-3; for a summary, see Dollery 2002). ${ }^{5}$ Yet while most commentators regard Australia's VFI as problematic, there is much less consensus about how it should be resolved.

Federalists argue that the VFI should be addressed by increasing the States' fiscal capacity through expanding their own-source tax base. At the very least it is argued that States need access to an earmarked percentage of national taxes under a regime which grants the States some control over the amount of revenue raised and how it is spent (Warren 2006: Ch. 2). In contrast, centralists argue that the most efficient strategy to address a VFI is for the national government to assume responsibility for the provision of services equivalent to its financial resources.

In between the two ends of this spectrum there are a number of intermediate positions. The most interesting compromises in this respect are funding models

\footnotetext{
${ }^{5}$ Dollery (2002) points out that Groenewegen has long argued that high levels of fiscal centralisation in a federal system tend to decrease administrative and compliance costs (Groenewegen 1990).
} 
which feature a national tax base and centralised administration while preserving the budgetary and governance capacities of sub-national government. For example, in both Germany and Canada, sub-national governments share significant tax bases (such as personal income tax) with national governments (Braund 2003). In practice this involves regional governments setting a surcharge on national taxes which is collected by the central government on their behalf. The goal here is to enhance the efficiency of the national tax system while preserving key aspects of the federalist ideal.

Another option of direct relevance to the Australian debate is for the national government, given its superior budgetary capacity, to assume financial responsibility for key services hitherto managed by the States, but under a governance model which promotes local management and control. The final section of this paper assesses the financial implication of one such transfer; a Commonwealth takeover of public hospitals.

\section{Reforming Fiscal Federalism: Challenges and Opportunities}

The most likely response to the growing financial pressures confronting the States will be a steady increase in tied Commonwealth assistance. Indeed, the forward estimates in the 2008-09 Federal Budget forecast SPPs (Special Purpose payments) to increase from $\$ 32.2$ billion (2007-08) to $\$ 36.9$ billion in 2011-12 (Commonwealth of Australia 2008b). In the crucial issue of health funding, the Rudd Government's four-year National Health and Hospitals Reform Plan will increase public-hospital funding by $\$ 2$ billion (subsequently increased to $\$ 3$ billion over five years in May 2008) so long as the States meet a range of specific reform targets (ALP 2007). While the initiative will help address the current shortfall being experienced by the States, the funding is unlikely to meet the increasing costs associated with running the hospital system unless massive efficiency savings can be achieved (Wells 2007; House of Representatives 2006).

In many ways, the National Health and Hospitals Reform Plan and the associated National Health and Hospitals Reform Commission are a template for the Rudd Government's new federalism agenda, which aims to create a culture of intense collaboration between the Commonwealth and State Labor governments (Kelly 2007). ${ }^{6}$ It appears that the recently elected Labor Government is genuinely committed to grant the States the independence to choose the means by which they improve service delivery. However, the Commonwealth seems much less willing to negotiate when it comes to establishing the goals of intergovernmental reforms. For example, in the Hospital Reform Plan it is quite clear that if the States fail to achieve agreed targets then the Commonwealth will give

\footnotetext{
${ }^{6}$ Prime Minister Rudd's first meeting with the Premiers in December 2007 established intergovernmental working groups for health, productivity, climate change and water, infrastructure, business competition, housing and indigenous affairs. The goal is to rationalise the 90 existing SPP into funding agreement per policy area. (Metherell 2007; Commonwealth of Australia 2008).
} 
consideration to a federal takeover of public hospitals (ALP 2007). Similarly, in education, the Rudd Government is taking an uncompromising position in promoting a national curriculum and uniform learning benchmarks despite the likelihood that this approach will result in conflict with State Labor governments. While the Rudd Government may have the skill and commitment to negotiate significant intergovernmental reforms, history indicates that there are real limits to partisan loyalties and it is likely there will be serious political conflicts between State Labor Premiers and the Federal Labor Government (Hamill 2006: 172-3). Or, as Greg Craven (2008) commented recently, 'COAG necessarily is a creature of stitches and patches. If we are going to approach some of the big issues of federalism, some heavy constitutional weaving will be required.'

Ultimately, cooperative federalism can only work when the States and the Commonwealth have shared interests. When these interests differ, the nature of the VFI in the Australian federation and the system of tied funding which it yields will inevitably result in cost shifting, accountability problems and intergovernmental conflict. Given these structural problems with Australian federalism, more fundamental reforms may be necessary.

\section{Transferring Public Hospitals}

As a result of the cost pressures and complex intergovernmental issues surrounding public hospitals it's not surprising that recent proposals to reform health services have focused on health funding. Perhaps the most significant and ambitious of these is the Rudd Government's National Health and Hospitals Reform Plan. While the plan aims to achieve a negotiated approach to improving the performance of Australia's public hospitals, the Federal Labor party has also expressed an intention to initiate a process whereby the Commonwealth would assume control of Australia's 750 public hospitals by mid-2009 if the States have not implemented the Reform Plan and its associated goals (ALP 2007). ${ }^{7}$ A central question for this paper is how much such a transfer would cost the Commonwealth and how it would impact on intergovernmental financial relations in Australia.

According to the most recent AIHW (2007: 55) report into Health Expenditure in 2005-06, total public spending on public hospitals was $\$ 22.4$ billion, of which the Commonwealth contributed $\$ 10.1$ billion (under the National Healthcare Agreement and other SPPs), with the States contributing \$12.3 billion. If the Commonwealth were to assume responsibility for public hospitals then the States could almost afford to relinquish all of their remaining non-hospital SPPs (\$14.7

\footnotetext{
${ }^{7}$ It must be noted that, away from heat of the election campaign, the federal Health Minister, Nicola Roxon, has been talking down the likelihood of the Commonwealth assuming control of public hospitals (Alexander 2008).
} 
billion for 2005-06), given the \$12.3 billion saved from existing hospital funding commitments.

Table 4: Net financial implications of public-hospital transfers (based on 2005-06 AlHW Data)

\begin{tabular}{|l|l|}
\hline Commonwealth & $+\$ 14.7$ billion (savings through cancellation of SPP to States) \\
\hline & $-\$ 12.3$ billion (assuming the States' share of $\mathrm{PH}$ funding) \\
\hline Net impact & $+\$ 2.4$ billion (in favour of the Commonwealth) \\
\hline
\end{tabular}

While there is clearly a shortfall of $\$ 2.4$ billion for 2005-06, it is important to note that the cost of running public hospitals is rising more rapidly than either revenue growth or other budget expenditures; so it is likely that if a review of public-hospital funding were to be considered in 2009, relinquishing SPP in return for the Commonwealth taking control of public Hospitals would be financially viable. As hospital costs increase, the States could be major financial beneficiaries of such a transfer (Productivity Commission 2005). So while centralised control of public hospitals would clearly offend the principle of subsidiarity and its normative commitment to decentralisation, in other important respects such a proposal has considerable merit. It would improve Australia's VFI and would eliminate the traditional cost and blame-shifting between Federal and State governments associated with both funding public hospitals and health policy more generally. Moreover, if the States agreed to relinquish SPPs as part of the transfer then it would enhance their political and financial independence over those areas where they retained political control.

\section{Conclusion}

This paper asked whether the 1999 IGA has succeeded in putting State public finances on a more sustainable footing. It argues that while GST revenues have increased at a rate of 8.9 per cent per annum in nominal terms over the period, a combination of the parlous condition of the States' remaining own-source taxes and the rapidly increasing expenditure pressures mean that the States are under increasing financial pressure. Given this situation, the second half of the paper sketched one proposal to reform Australian fiscal federalism. The Rudd Government's proposal to assume financial responsibility for Australia's 750 public hospitals has three clear advantages. Firstly, it would resolve the myriad cost-shifting and accountability problems which have afflicted federal-state relations in the area of health policy. Second, it would help restore the fiscal balance in the Australian federation by assigning the area of fastest public-expenditure growth to the level of government with the greatest fiscal capacity. Finally, at a political level, the health-reform agenda seems to be gathering momentum and there is a growing willingness among State and Federal governments to consider radical reform proposals such as transferring responsibility for public hospitals to the Commonwealth. Only time will tell if 
such an initiative becomes a defining achievement of the Rudd Government's first term.

\section{References}

ABS 2007, 'Taxation Revenue 2005-06' (5506.0), Australian Bureau of Statistics, Canberra.

ABS 2008, 'House Price Indexes: Eight Capital Cities' (6416.0), March, Australian Bureau of Statistics, Canberra.

AIHW 2007, 'Health Expenditure Australia 2005-06', Australian Institute of

Health and Welfare, Canberra, at: http://www.aihw.gov.au/publications/ index.cfm/title/10529

Alexander, C. 2008, 'Health System and Renovator's Dream', The Australian, 8 May 2008.

AMA 2007, Public Hospitals Report Card, Australian Medical Association, at: http://www.ama.com.au/web.nsf/

BCA 2007, A Charter for a new federalism, Business Council of Australia, Melbourne, at: <http://www.bca.com.au/Content/101308.aspx>

Bird, R. and Ebel, R. 2006, 'Subsidiarity, Solidarity and Asymmetry' ITP Working Paper 509, Toronto.

Braun, D. 2003, Fiscal Policies in Federal States, Ashgate, Aldershot.

Collins, D. and Warren, N. 2006 'The States and the GST: Demystifying Australian Federal/State financial arrangements', Australian Tax Research Foundation, Sydney.

Commonwealth of Australia 2007, Budget Paper no.3: Federal Financial Relations 2007-08, at: http://www.budget.gov.au/2007-08/bp3/html/index.ht

Commonwealth of Australia 2008a, 'The architecture of Australia's Tax and Transfer System' at: http://taxreview.treasury.gov.au/

Commonwealth of Australia 2008b, Budget Paper no.3: Federal Financial Relations 2008-09, at: http://www.budget.gov.au/2007-08/bp3/html/index.ht

Costello, P. 1998, 'A New Tax System', media release, 13 August 1998.

Costello, P. 2004, 'Doorstop interview', 24 March 2004.

Craven, G. 2008 'Time right to fix federalism', Australian Financial Review, 12 April 2008.

Dollery, B. 2002, 'A Century of Vertical Fiscal Imbalance in Australia', History of Economics Review 36.

Ebrill, L. et al. 2001, The Modern VAT, IMF, Washington DC. 
Eccleston, R. 2004, The Thirty Year Problem: The politics of Australian Tax Reform, The Australian Tax Research Foundation, Sydney.

Ferguson, A. 2007, 'State ponders the $\$ 21$ billion appeal of privatisation', The Australian, 8 September 2007.

Fitzgerald, V. 1998, 'Tax Reform and Federal-State Financial Relations', Quarterly Bulletin of Economic Trends 3.

Freebairn, J. 2002, 'Opportunities to Reform State Taxes', Australian Economic Review 35(4): 405-22.

Groenewegen, P. 1990, Public Finance in Australia (3 ${ }^{\text {rd }}$ ed.), Prentice-Hall, Sydney.

Hamill, D. 2006, The Impact of the New Tax System on Australian Federalism, The Australian Tax Research Foundation, Sydney.

House of Representatives 2006, Inquiry into Health Funding, at: http://www.aph.gov.au/house/committee/haa/healthfunding/report.htm

Kelly, P. 2007, 'The Rudd Agenda', The Australian, 22 December 2007.

Mathews, R. and Grewal, B. 1997, The Public Sector in Jeopardy: Australian Fiscal federalism from Whitlam to Keating, Melbourne: Centre for Strategic Economic Studies, Victoria University of Technology.

Productivity Commission 2004, First Home Ownership, at: http://www.pc.gov.au/inquiry/housing/docs/finalreport

Productivity Commission 2005, Economic Implications of an Ageing Australia, at: http://www.pc.gov.au/study/ageing/docs/finalreport

Queensland Government 2007, State and Territory Concerns in Relation to the $A H C A$ at: http://www.health.qld.gov.au/publications/ aust_hlth_care_agreement/

Row, R. and Duhs, A. 2001, 'The National GST and Commonwealth-State Financial Relations: A Neglected Issue', Economic Analysis and Policy 31(1).

Rudd, K. 2007, 'Facing the Future - An address to the National Press Club', at: http://www.alp.org.au/download/070417_sp_npc.pdf

Smith, G. 2007, 'Australia's Aggregate Tax Burden', The Australian Tax Research Foundation, Sydney.

Tiebout, C. 1956, 'A pure theory of local expenditures', Journal of Political Economy 64.

Twomey, A and Withers, G. 2007, Australia's Federal Future, Federalist Paper 1, A Report for the Council for the Australian Federation. 
Warren, N. 2006, Benchmarking Australia's Intergovernmental Fiscal Arrangements — Final Report, at: http://www.treasury.nsw.gov.au/_data/assets/ pdf_file/0006/5793/fin-bench-rep.pdf

Wells, R. 2007, 'Rudd's Hospitals Takeover - Read the fine print', at: http://www.crikey.com.au/Politics/20070824-Hospitals-takeover-Read-thefine-print.html

World Bank 2000, World Development Report 1999-2000, Oxford, Oxford University Press. 


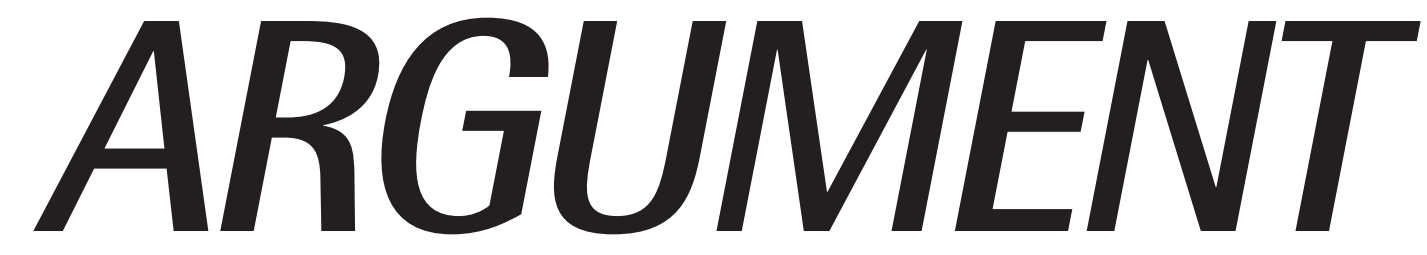





\title{
Getting Real about Adapting to Climate Change: Using 'Real Options' to Address the Uncertainties
}

\author{
Leo Dobes ${ }^{1}$
}

\begin{abstract}
Scientists predict that some climate change is already inevitable, even if greenhouse emissions are stabilised. Adaptation strategies will be of comparable importance to reducing emissions. However, the specific effects of climate change are currently unknowable, especially at the local level. Given this uncertainty, deterministic adaptation strategies are inappropriate. Rather than building 'worst-case scenario' sea walls, for example, strong foundations can be laid - so that walls can be built (or not built) in future to match actual climatic conditions without incurring unnecessary upfront expense. Other examples of such 'real options' are provided to illustrate the feasibility of the approach.
\end{abstract}

\section{Introduction}

Scientists have for some time predicted that climate change is already inevitable, even if greenhouse emissions are stabilised (for example, Houghton et al. 1990: xxii). Pittock (2003: 46) points out that inertia and time lags in the climate system will result in climate-change impacts on Australia continuing 'long after greenhouse gas emissions have been reduced, and will be dictated largely by cumulative emissions in the past century and the coming decades'.

If we accept that increased atmospheric concentrations of greenhouse gases cause climate change, then logic dictates that we should already be thinking as much about adapting to climate change as about mitigating (reducing) emissions. ${ }^{2}$ But adaptation strategies require an entirely different policy approach from mitigation measures.

\footnotetext{
${ }^{1}$ Crawford School, the Australian National University, Leo.Dobes@dobes.com.au

2 The author is grateful to the Editor and each of the three anonymous referees for commenting on an early draft of this paper. One referee proposed that the paper explicitly acknowledge that 'climate change has already been detected and has been rigorously attributed to human causes. ... The hotter, drier climate is already here ...'. The present author, however, respectfully disagrees with this contention. While a significant (but not unanimous) body of scientific opinion supports the view that anthropogenic emissions of greenhouse gases are causing climate change, the potential contribution of non-anthropogenic causes has yet to be established. In any case, the argument in this paper does not depend on the existence of any current change in climate, but only on the possibility of future climate change (for whatever reason), and uncertainty about its extent. Nor does it depend on the attribution of climate change to anthropogenic factors.
} 
By and large, policymakers can select a mitigation measure such as a carbon tax, or the replacement of incandescent globes with fluorescent lighting, and estimate with a degree of certainty the expected reduction in emissions. Within reasonable bounds, the social costs of each measure can also be estimated with some certainty. Policymakers can therefore be relatively confident about choosing the most cost-effective measure or mix of measures for reducing national levels of greenhouse emissions.

Adaptation strategies, in contrast, involve a great deal of uncertainty. Climate-change models are based on global scenarios whose likelihood of occurrence is difficult to determine in practice. And while models are improving, predicting climatic effects at the local level - where adaptation necessarily needs to take place - entails additional uncertainty. Although Australians have considerable experience in adapting to climatic extremes, there is little specific information available to guide decision-makers facing new circumstances.

In acknowledging - rather than ignoring - the existence of uncertainty about the specific extent and effects of future climate change, this article posits that past thinking has been overly linear and deterministic. At the risk of generalisation, the focus has been on identifying a likely effect (for example, melting of the Arctic ice cap), the consequential risk (for example, rising sea levels), and the 'obvious' remedy (for example, building sea walls). Thinking at the political level in Australia has similarly focused on identifying potential risks and responses, and has advanced little for almost two decades.

But deterministic approaches are a potentially misleading basis for implementing adaptation measures because the specific extent and timing of any future climatic change is highly uncertain. Except by pure chance, deterministic responses are likely to be either inadequate (flooding due to sea walls being too low, or built too late) or unnecessarily wasteful of scarce community resources (sea walls too high, or built earlier than needed).

The paper first reviews briefly some of the literature on adaptation, concluding that knowledge of the effects of climate change - especially at the local level - is subject to a high degree of uncertainty and is often presented as little more than very general lists of various risks. A review of the conceptual thinking by Australian governments about adaptation issues is shown in the next section to have changed little over the last two decades, and two examples are provided to illustrate the tension between the bureaucratic preference for deterministic planning and the uncertainties that surround climate change. The main part of the paper presents a series of examples illustrating how the problem of uncertainty can be more appropriately addressed by increasing the flexibility of adaptation measures by employing 'real options'. The final part of the paper proposes that the role of government in adaptation to climate change should be limited to issues that involve genuine market failure. 


\section{Impacts assessment: the Mikado's little list ${ }^{\mathbf{3}}$}

Although adaptation as an issue has not been entirely ignored in the past, the scientific and academic literature appears to have blossomed only in the last two or three years.

Contributors to the latest Intergovernmental Panel on Climate Change report are aware of the body's comparative neglect of adaptation issues over the last decade and a half. Klein et al. (2007: 753), for example, acknowledge that the UNFCCC [United Nations Framework Convention on Climate Change], its subsidiary bodies and Member Parties have largely focused on mitigation', and Schneider et al. (2007: 797) concede that 'the scientific literature on [adaptation] is less well developed than for mitigation, and the conclusions are more speculative in many cases'.

At one extreme, it is possible that some in the scientific and environmentalist communities may have subscribed, consciously or unconsciously, to a paradigm of salvation in which only mitigation strategies can save the world from climatic catastrophe. In Tol's (2005: 572) view, 'it was politically incorrect to speak about adaptation to climate change, because it presumably implies accepting defeat in the battle against evil emissions'. While Pielke et al. (2007: 597) agree, they also point out that 'during early policy discussions on climate change in the 1980s, adaptation was understood to be an important option for society'.

A more liberal explanation of the comparative neglect of adaptation may be that the lack of scientific certainty about climate change made analysts cautious until the IPCC's Third Assessment Report in 2001. In a 1995 IPCC synthesis report, Bolin et al. (1995: para 2.5), for example, state that 'there are inadequate data to determine whether consistent global changes in climate variability or weather extremes have occurred over the $20^{\text {th }}$ century'. Only with the drama of more recent extreme weather events such as protracted drought in Australia, Hurricane Katrina in the United States, severe floods in many parts of the world, the 2003 heat waves in Europe, as well as the publicity surrounding the 2006 Stern Review, has public attention focused on the possible effects of climate change.

A good deal of the emphasis in the scientific literature has been the identification of generic risks and vulnerabilities. The impacts of climate change are often assessed in the technical literature in terms of criteria (Schneider et al. 2007: 785) such as the magnitude of an effect (for example, the number of people or the area affected) or its timing (soon, or in the distant future), or persistence and reversibility (for example, the loss of major ice sheets or the shutdown of

3 The allusion is to eponymous productions of the Gilbert and Sullivan operetta where the Mikado produces a 'little list' of people who irritate him. The list is, in fact, quite lengthy, follows no underlying principle, and varies from production to production to ensure 'relevance'. 
the meridional overturning circulation). Further, 'the literature on adaptation costs and benefits remains quite limited and fragmented in terms of sectoral and regional coverage. ... Much of the literature ... is focused on sea-level rise ... and agriculture' (Adger et al. 2007: 724-5).

A medley of lists and categories of various 'vulnerabilities' has developed to indicate areas of greatest priority in addressing adaptation to climate change. For example, Schneider et al. (2007: 787-9) list categories that include often-overlapping areas such as food supply, aggregate market impacts and distribution, health, water resources, infrastructure, fire, marine ecosystems and biodiversity, and so on. But such lists in themselves provide little or no guidance on what should be done, or when, or by how much, by way of adaptation.

The academic, policy-related literature ranges across perspectives as diverse as Orlove's (2005) anthropological examination of the collapse of the classic Mayan civilisation and the abandonment of Viking settlements in Greenland, England's (2007) exploration of legal liability aspects, Berkhout's (2006) pessimism about the willingness of commercial organisations to experiment in adaptation techniques, warnings by McMichael (2004) and Woodruff et al. (2006) about the spread of malaria and dengue fever, reports about the melting of roadways and buckling of railway lines by DuVair et al. (2002), and the spectre of an invasion of Australia's shores by environmental refugees from the Pacific Basin raised by Furnass (2007), based on work by Dupont and Pearman (2006). Again, however, there is no clear indication of what exactly should be done, or when, or by how much.

Both the scientific and the policy-oriented literature suffer from the problem of being based on the output of climate-change models. They are therefore able to provide little more than general indications of potential climate risks because the results from climate-change models are average (that is, trend) values, whereas adaptation necessarily needs to address extreme weather events (the outlying probabilistic points around the trend line). More importantly, climate models are based on simulations of possible scenarios of future atmospheric concentrations of greenhouse gases. And there is enormous uncertainty about which scenario is the most likely, or even whether governments will reach and enforce a clear international agreement on mitigation levels that might help determine a likely scenario.

The upshot of this situation, unfortunately, is that the information currently available to governments and the public offers very little certainty about the specific effects of any climate change, and hence cannot provide useful guidance regarding the extent or timing of policy responses. 


\section{Australian governments: more of the same}

Australia's political consideration of adaptation issues has, to date, also focused mainly on cataloguing risks and promoting further research, with little tangible development over almost two decades of practical policy frameworks for implementing adaptation responses.

On 11 October 1990, the Minister for Arts, Sport, the Environment, Tourism and Territories, Ros Kelly, and the Minister for Primary Industries and Energy, John Kerin, jointly announced that the Commonwealth Government had adopted an interim planning target to reduce emissions of greenhouse gases by 20 per cent by the year 2005. The two ministers also announced that a referral had been made to the Industry Commission to prepare a report on the cost-benefit implications for Australian industry of such a target, and that Ecologically Sustainable Development working groups would be established to report to the Government on a range of greenhouse-gas-related measures. However, there was no reference to adaptation issues in the announcement itself.

The Industry Commission (1991:2) report commented that the state of scientific knowledge at the time did 'not allow any reasonable estimate to be made of the impacts that would be avoided by a global reduction in greenhouse gas emissions' but refers only in passing to the possibility of adaptation measures. The Ecologically Sustainable Development working groups issued various sectoral reports in 1991 but do not appear to have covered directly issues related to adaptation to climate change. Nor does the National Strategy for Ecologically Sustainable Development (Commonwealth of Australia 1992b) - an outcome of the working group process - deal with adaptation.

The first Special Premiers' Conference, held in October 1990, issued a communiqué announcing an intention to develop an Intergovernmental Agreement on the Environment (IGAE), and Prime Minister Paul Keating's One Nation statement of 26 February 1992 announced that agreement had been reached on this. Schedule 5 of the IGAE provided for the development of a National Greenhouse Response Strategy (Commonwealth of Australia, 1992a), which was published in December 1992 with the endorsement of the Council of Australian Governments (COAG).

Adaptation does feature, however, in both of the main parts of the National Greenhouse Response Strategy (NGRS): 'Specific Sectoral Strategies' and 'Measures Already Underway'. Its objective is stated as being to 'protect Australia's natural, human and built environment from the potential impacts of the enhanced greenhouse effect' (Commonwealth of Australia 1992a). Strategies for achieving this aim include:

- conducting research into the potential impacts of the enhanced greenhouse effect, including development of techniques to assess vulnerability; 
- assessment of the vulnerability of the natural, built and human environment to climate change;

- incorporation of planning for possible impacts of the enhanced greenhouse effect into existing conservation and planning strategies;

- incorporation of information on the potential impacts of the enhanced greenhouse effect into disaster planning; and

- ensuring that natural-resource management (for example, agriculture and forestry) regimes take into account the potential impacts of climate change.

Some of the measures identified as being already under way (Commonwealth of Australia 1992a: 60-1) included research by the CSIRO, various monitoring activities to assess the extent and impact of climate change, expert workshops, and the development by 'some State and Territory Governments and local councils [of] ... new planning regimes in recognition of the potential for changes in sea level, flooding and storm surges'.

Apart from a reformulation of the NGRS into the 1998 National Greenhouse Strategy (NGS) following a review initiated in 1996 (Productivity Commission 1999: 227), COAG appears to have given little or no active attention to the issue of adaptation for more than a decade after it endorsed the NGRS. It was only in February 2006 that COAG agreed to a Climate Change Plan of Action (http://www.coag.gov.au/meetings/100206/index.htm) that included development of a national adaptation framework, and the April 2007 meeting of COAG endorsed a National Climate Change Adaptation Framework.

The new National Climate Change Adaptation Framework reveals little conceptual progress from the content of the 1992 NGRS. It proposes the establishment of an Australian Centre for Climate Change Adaptation (since established at Griffith University) and identifies additional risks such as fires, mosquito-borne infections, heatwaves, and the spread of invasive species. Overall, however, it is at least arguable that it does little more in essence than the NGRS in calling for more research, identification and assessment of risks and vulnerabilities, and their incorporation into decision-making in sectoral areas of concern.

State governments have separately issued various reports and action plans. The Victorian Government has published a comprehensive climate-change adaptation program that includes risk assessments and publications such as State of Victoria (2007). Other states have similar plans and publications, and non-governmental organisations such as the Agriculture and Land Management Working Group (2003) and Engineers Australia (2004) have also addressed issues of risk and adaptation. However, the review of likely health impacts of climate change by the Department of Health of Western Australia (2007) is unusual in that the Executive Summary recognises explicitly that the lack of detailed 
knowledge of future climatic conditions in Western Australia ... did not allow for a comprehensive and quantitative assessment of health impacts'.

\section{Uncertainty makes deterministic planning dangerous}

As well-intentioned as it might be, deterministic planning in the face of inevitable uncertainty about the detail of climate change poses the risk of serious misallocation of society's resources. An example of the tension between the lack of knowledge about specific climate-change effects, and the bureaucratic impulse to plan, appears in Voice et al. (2006). It is worth quoting at length:

There have been many evaluations of severe wind risk in the current climate ... There has been less work performed on wind risk in a warmer world ... Little progress has been made since [a cited 2001 study] on improving the climate change scenarios that dictate the precise amount of future vulnerability. (Section 6.3.1: 50)

While specific case studies of the vulnerability of ports to climate change have not been performed, ports have generally used the National Committee on Coastal and Engineering guidelines ... to make allowance for climate change effects. ... Major new port infrastructure is thoroughly assessed for the impacts of climate change in the design phase. ... For example, the proposed new offshore wharf structure and expanded coal terminal in the Port of Abbot Point in Queensland ... studied a number of greenhouse potential impacts. The new facilities were designed for expected water level changes predicted over the next 100 years (conservatively estimated at 0.2 metres to 0.5 metres) ... New port infrastructure therefore is well prepared for the impact of climate change. (Section 6.3.2: 50-1)

The following piece of advice by the federal Department of Climate Change on how to adapt to climate change also illustrates the point well: 'Early planning for the impacts of climate change is likely to bring considerable advantages. Many decisions made today will have consequences for decades. It is cheaper, for example, to design new housing or infrastructure to cope with a future climate than to retrofit later.' (http://www.greenhouse.gov.au/impacts/howtoadapt/ indexs.html; viewed 6 July 2008, emphasis added)

One presumes that the Department undertook some careful calculations before proffering this advice. But what do such sums amount to in the face of uncertainty about the extent and timing of specific climate-change effects for each locality in Australia? Is it really cheaper to build a house designed to withstand an absolute worst-case scenario (and which one?), or did the Department mean something less drastic? Indeed, it might in fact be even cheaper to build a flimsy non-climate-proofed house now, and rebuild it, if necessary, once the true extent and timing of any climate change becomes much more 
certain. And would it not be socially more desirable to keep current expenditure on housing to a minimum, in case cities need to be redesigned to take account of mitigation measures that reduce transport needs and increase housing density?

Clearly, uncertainty about the specific nature and extent of any future climate change militates against apparently straightforward, deterministic policy prescriptions.

\section{'Real options': a cleverer option}

A more fruitful perspective on measures for adapting to climate change is that they resemble investment decisions under conditions of uncertainty.

An investor facing the possibility of a high return on an asset can purchase an option, rather than the more expensive share itself. This (financial) option gives the investor the contractual right, but no obligation, to purchase the asset should its value rise above a specified level ('the strike price'), on or before a specified date. If the market price of the asset rises above the specified 'strike price', the investor can profit by exercising the option and so obtain the share at below market price. If the share price remains low, or falls, the investor forgoes the opportunity to purchase the asset because there would be no gain in doing so, but loses only the cost of the option that was purchased. Such options are valuable because they allow an investor to delay a final decision on purchasing a relatively more expensive share until there is greater certainty about the share price.

An analogous possibility often exists in the realm of physical (so-called real) capital. An everyday example of a 'real option' might be a couple buying a house, but uncertain about when, or if, they will have children, or how many children. Buying a large house immediately could be unnecessarily costly if they remain childless, or if they delay starting a family for a significant time. But they could buy a smaller, cheaper house on a suitable block of land and extend it later, as required. The smaller house in effect 'embeds' an option to extend, but there is no obligation to do so if the family remains small. The couple can delay a final decision on the size (and hence the full cost) of the house until better information becomes available regarding specific family size.

In applying the 'real options' approach to decisions made by firms, management theorists often use the term 'strategic options' to reflect deliberate commercial strategies to create flexibility in investment decisions where outcomes are uncertain. Raynor (2007), for example, employs this perspective in analysing joint ventures and the entry of firms into foreign markets. Nerkar et al. (2007) apply similar reasoning to the acquisition of patents.

Dixit and Pindyck (1994) explore in detail the methodology for evaluating real options, and the use of such values in cost-benefit and investment analysis. 
They point out (pp.3-4) that most investment decisions share, in varying degrees, the following key characteristics:

- The investment is partially or completely irreversible. That is, at least part of the initial cost is 'sunk' because it cannot be recovered even if the rest of the investment process does not proceed. If all costs were recoverable, there would be no value in delaying the full implementation of the investment.

- There is uncertainty over the future rewards or payoffs from the investment.

- There exists the ability or opportunity to delay the timing of the investment, at least partially.

- More information about potential rewards or payoffs (but never complete certainty) becomes available during any procrastination.

Apart from its greater realism, the real options approach represents an important analytical advance on orthodox Net Present Value analyses that take as given assumed future streams of costs and revenues or benefits. The concept is also readily applicable to the design and evaluation of measures intended to ameliorate the effects of any future climate change.

\section{Identifying and creating 'real options' in adapting to climate change}

The potential application of the real options approach to climate-change adaptation measures can be illustrated with a number of hypothetical but realistic examples.

One example is in the construction of a new airport runway. In a hotter climate, longer runways may be required to allow planes to develop sufficient lift to take off safely with full loads. (An alternative may be more-powerful engines, but noise issues may preclude this option.) It would be expensive to build a long runway immediately, and may turn out to be an unnecessary cost if temperatures do not increase as much as initially anticipated. In this situation of uncertainty about climate-change impacts, a 'real option' could be the construction of a normal runway, but accompanied by the purchase of additional land at the end of the runway to allow for a possible extension later, if required. In other words, the airport operator does not need to commit the full extent of funding immediately.

Because the additional land can also be leased to short-term users for such things as freight warehouses, car parking, grazing of animals, and so on, the cost of the 'land purchase' option can be offset to some extent. But an even more effective approach could be to build a normal runway and purchase only an option to buy the additional land at the end of the runway. That is, enter into a contract with the owner of the land to purchase it within a specified period, for a specified sum, if some specified temperature criterion is met. An option to purchase the land would normally be cheaper than buying it outright. 
A similar heuristic could be used to address the problem of flooding in low-lying areas. As an alternative to blocking development in such areas, or building high protective barriers immediately, it may be worthwhile constructing only the base of a wall or embankment, but one that is capable of supporting a, say, 10-metre wall. This approach creates an option to build a high wall later, if required. It also affords the option of building a low wall, and raising it later, if required, or just providing a solid base for sandbagging for occasional emergencies. In other words, the full cost of a high wall is not incurred unless, and until, it is really required, and the base can be used to ameliorate the effects of less extreme weather events as well.

Military equipment often embeds real options. For example, ships may be 'fitted for but not with' missile-launching or other capabilities. This approach reduces the initial capital expenditure and affords the military the option of acquiring the most up-to-date equipment at the time that it is actually needed. If it is not needed, little additional opportunity cost is incurred. A similar approach could be applied to transport vehicles. Trains or buses can be 'fitted for but not with' larger air-conditioning units, for example, but the equipment would be installed in the future only if increased temperatures warranted the additional expenditure.

Long-lived infrastructure such as a road or railway is particularly suited to the real-options investment approach. For example, there may be considerable uncertainty about the extent to which low-lying land will be more flood-prone in, say, 2050, but a road or railway needs to be built immediately in the area. Rather than constructing roads or railways on expensive raised embankments, or choosing longer alternative routes, one approach may be to purchase additional adjoining land to form a wider corridor. If required in future, the corridor can be used to build levee banks or to place gabions to protect the road or railway from floodwaters. Sunk costs can be minimised if the land is not in fact required in the future, by selling it to housing developers, or leasing it to owners of pipelines, or telecommunications or electricity lines.

Nor do cities or buildings necessarily require the immediate development and use of expensive new materials and designs. Rather than investing immediately in expensive new technology, cheaper options that can buy time include making provision for the future use of shade blinds for windows and walls, increasing the albedo ${ }^{4}$ of walls and roofs through painting, or the planting of deciduous vegetation next to or near buildings and along streets. Taha et al. (1997), for example, found that a moderate increase in vegetation could reduce temperatures in California's South Coast Air Basin by $2-3^{\circ} \mathrm{C}$, with comparable results in other studies such as Shashua-Bar and Hoffman (2004). Street trees in

\footnotetext{
4 In general terms, albedo is the 'reflectivity' of an object. Black bodies have zero or low albedo, and bright matter such as ice or snow have a high albedo.
} 
particular can reduce the sunk social cost of investment through the positive externality of enhancing the attractiveness of urban areas.

In a rare application of the real-options approach, Nordvik and Liso (2004) model possible responses by building owners to climate change, finding that uncertainty about climate change may reduce rates of conversion (for example, to withstand higher winds) as well as reducing the scrapping of buildings, as well as maintenance effort: that is, the model posits increased economic lifetimes of buildings in the face of uncertainty. Another option may be to build cheaper houses and commercial accommodation with shorter design lives, and to reduce maintenance on them. This approach opens up the possibility of the earlier scrapping of buildings and reconstructing with materials that are more appropriate to whatever climatic conditions prevail at the time. Earlier scrapping of buildings will increase flexibility and options for redesigning whole cities for example to increase density — should that be found desirable in the future.

Application of the real-options approach is not limited to physical infrastructure. Australian farmers have practised the concept for many years in dealing with a historically highly variable climate. At times of insufficient water availability, farmers who have prepared their land for a cotton crop, for example, may exercise the option of planting sorghum instead. Other potential agricultural options include the operation of several farms in geographically diverse locations, rather than a single farm, and the use of versatile livestock such as the South African Meat Merino (see ABC (2006); and The Prime SAMM Society of Australia) which offers the option of producing either wool or meat, depending on weather and market conditions. The legendary cattle king, Sir Sidney Kidman, effectively created a real option with respect to cattle by acquiring a string of contiguous landholdings north to south across Australia to facilitate movement of his livestock from drought-affected areas to water and pasture elsewhere.

With appropriate input from medical practitioners, real options could also be developed for the health sector. In the case of concerns about the spread of malaria, research itself provides an option, and is preferable to expensive (and possibly misguided) investment in specialised malaria hospitals or training more medical personnel. An example of a real option might be for Australia to fund a specialist domestic or foreign company to undertake research into new anti-malarial drugs in return for cheap drugs to Australian residents in the event that malaria does become endemic.

Care also needs to be taken to incorporate real options into some popular mitigation strategies. An example is government subsidies for solar panels to reduce the use of fossil fuels. Such subsidies may come to be seen as incongruous in the future if predictions of more severe weather events such as the hailstorms in Sydney and Queensland become commonplace, and solar panels suffer extensive weather damage. To ensure continuity of electricity supply, a real 
option might be to include fittings on the panels during installation to allow later attachment of wire mesh or some other cheap protective device, in case hailstorms do become prevalent in the future.

With sufficient foresight, determination and creativity, it is possible to identify 'real options' for other areas of social and economic life that may be affected by future climate change. The identification of flexible options, not the deterministic prescription of 'obvious' solutions, should be the preferred approach to formulating adaptation policy.

\section{Steering, not rowing: the role of government}

It is not the intention here to explore in detail the appropriate role of governments in formulating adaptation strategies. But a case can readily be made for refocusing bureaucratic thinking and activity into the following areas:

- Addressing genuine instances of market failure, such as lack of information, by supporting research into likely effects of climate change, but at a specific level relevant to local conditions.

- Taking a leading role where externalities occur. For example, if levee banks are required to prevent flood damage, it will be necessary to ensure that the affected riparian landowners all build and maintain adequate flood defences to avoid flooding from neighbouring properties with inadequate levee banks. However, cost recovery - perhaps in the form of income-contingent loans proposed by Chapman (2006) - may be appropriate if land values are enhanced through government support.

- Identification and removal of bureaucratic impediments to adaptation by the private sector. (Local council bans on rainwater tanks in urban households are still well within living memory.)

- Fostering the identification of potential real options in adaptation strategies, and public dissemination of information on the results.

\section{Conclusion}

Although the 'real options' approach outlined above is addressed by established economic theory, it reflects the common sense that most humans apply to situations where there is uncertainty about the future. By not fully committing to a policy or course of action until more information becomes available, better outcomes are ultimately more likely. In economic terms, society as a whole can improve its wellbeing because it can attain its objectives using fewer resources, and those resources can be used for other purposes.

It may not always be easy to identify appropriate 'real options' for measures designed to adapt to climate change. But unless a serious effort is made to do so, governments will be tempted to spend too much, too soon. 


\section{References}

ABC 2006, 'Wool growers turn into meat producers', Landline program 8 October 2006, Australian Broadcasting Corporation, $<$ http://abc.net.au/landline/content/2006/s1757239.htm >.

Adger, W. N., Agrawala, S., Mirza, M. M. Q., Conde, C., O'Brien, K., Puhlin J., Pulwarty, R., Smit, B. and Takahashi, K. 2007, 'Assessment of adaptation practices, options, constraints and capacity', in Intergovernmental Panel on Climate Change: 717-43.

Agriculture and Land Management Working Group 2003, Implications of Climate Change and Greenhouse policy for Rural and Regional Australia, report to the Commonwealth Government as part of the Government-Business Climate Change Dialogue, Canberra.

Chapman, B. 2006, Government Managing Risk. Income Contingent Loans for Social and Economic Progress, Routledge, U.K.

Commonwealth of Australia 1992a, National Greenhouse Response Strategy, December, Australian Government Publishing Service, Canberra.

Commonwealth of Australia 1992b, National Strategy for Ecologically Sustainable Development, December, Australian Government Publishing Service, Canberra.

Council of Australian Governments (various years 1992-2007), COAG Meeting Outcomes, http://www.coag.gov.au/meetings/100206/index.htm, viewed 27 February 2008.

Department of Health of Western Australia 2007, Health Impacts of Climate Change: Adaptation Strategies for Western Australia, Perth.

Dixit, A. K. and Pindyck, R. S. 1994, Investment Under Uncertainty, Princeton University Press, New Jersey.

Dupont, A. and Pearman, G. 2006, 'Heating up the Planet. Climate Change and Security', Paper 12, Lowy Institute, Sydney.

duVair, P., Wickizer, D. and Burer, M. J. 2002, 'Climate change and the potential implications for California's transportation system', in The Potential Impacts of Climate Change on Transportation: Workshop Summary and Proceedings, U.S. DOT (Center for Climate Change and Environmental Forecasting) in cooperation with U.S. EPA, U.S DEA, U.S. GCRP, at $<$ http://climate.dot.gov/publications/workshop1002/duvair.pdf $>$, viewed 19 March 2008.

Engineers Australia 2004, Guidelines for Responding to the Effects of Climate Change in Coastal and Ocean Engineering, prepared by the National Committee on Coastal and Ocean Engineering, Canberra. 
England, P. 2007, 'Climate change: what are local governments liable for?', Issues Paper 6, Urban Research Program, Griffith University, Queensland.

Furnass, B. 2007, 'Environmental and climate change refugees', Draft discussion paper for Doctors for the Environment, <http://www.manningclark.org.au/newsletter/nl30_furnass.html> viewed 16 March 2008.

Industry Commission 1991, 'Costs and Benefits of Reducing Greenhouse Gas Emissions', Volume I: Report, Volume II: Appendixes, Report No. 15, 15 November, Australian Government Publishing Service, Canberra.

Bolin, B., Houghton, J. T., Meira Filho, G., Watson, R. T., Zinyowera, M. C., Bruce, J., Lee, H., Callander, B., Moss, R., Haites, E., Acosta Moreno, R., Banuri, T., Dadi, Z., Gardner, B., Goldemberg, J., Hourcade, J-C, Jefferson, M., Melillo, J., Mintzer, I., Odingo, R., Parry, M., Perdomo, M., Quennet-Thielen, C., Vellinga, P., Sundararaman, N. 1995, IPCC Second Assessment Synthesis of Scientific-Technical Information relevant to interpreting Article 2 of the UN Framework Convention on Climate Change, http://www.ipcc.ch/pdf/climate-changes-1995/ 2nd-assessment-synthesis.pdf, viewed 27 February 2008.

Intergovernmental Panel on Climate Change (2007), Climate Change 2007: Impacts, Adaptation and Vulnerability. Contribution of Working Group II to the Fourth Assessment Report of the Intergovernmental Panel on Climate Change, Parry, M. L., Canziani, O. F., Palutikof, J. P., van der Linden, P. J. and Hansen C. E (eds), Cambridge University Press, UK.

Klein, R. J. T., Huq, S., Denton, F., Downing, T. E., Richels, R. G., Robinson, J. B., Toth F. L. 2007, 'Inter-relationships between adaptation and mitigation' in Intergovernmental Panel on Climate Change 2007: 745-77.

McMichael, A. J. 2004, 'Environmental and social influences on emerging infectious diseases: past, present and future', Philosophical Transactions of the Royal Society, London, B 359: 1049-58.

Nerkar, A., Paruchuri, S. and Khaire, M. 2007, 'Business method patents as real options: value and disclosure as drivers of litigation', in Reuer, J. J. and Tong T. W. (eds) 2007, Real Options Theory, volume 24 of Baum, J. A. C. (series editor), Advances in Strategic Management, Elsevier JAI, Oxford: 247-74

Nordvik, V. and Liso, K. R. 2004, 'A primer on the building economics of climate change', Construction Management and Economics 22, September: 765-75.

Orlove, B. 2005, 'Human adaptation to climate change: a review of three historical cases and some general perspectives', Environmental Science \& Policy 8: 589-600. 
Pielke, R., Prins, G., Rayner, S. and Sarewitz, D. 2007, 'Lifting the taboo on adaptation', Nature 445 (8 February): 597-8.

Pittock, B. (ed.) 2003, Climate Change: An Australian Guide to the Science and Potential Impacts, Commonwealth of Australia, Canberra.

Productivity Commission 1999, 'Implementation of Ecologically Sustainable Development by Commonwealth Departments and Agencies', Report No. 5, 25 May, AusInfo, Canberra.

Raynor, M. E. 2007, The Strategy Paradox: Why Committing to Success Leads to Failure (and What to do about it), Currency Doubleday, New York.

Schneider, S. H., Semenov, S., Patwardhan, A., Burton, I., Magadza, C. H. D., Oppenheimer, M., Pittock, A. B., Rahman, A., Smith, J. B., Suarez, A. and Yamin, F. 2007, 'Assessing key vulnerabilities and the risk from climate change' in Intergovernmental Panel on Climate Change (2007): 779-810.

Shashua-Bar, L. and Hoffman, M. E. 2004, 'Quantitative evaluation of passive cooling of the UCL microclimate in hot regions in summer, case study: urban streets and courtyards with trees', Building and Environment 39: 1087-99.

State of Victoria 2007, 'Climate Change and Infrastructure: Planning Ahead', information prepared by CSIRO, Department of Sustainability and Environment, Melbourne.

Taha, H. 1996, 'Modeling impacts of increased urban vegetation on ozone air quality in the South Coast Air Basin', Atmospheric Environment 30(20): 3423-30.

Tol, R. S. J. 2005, 'Adaptation and mitigation: trade-offs in substance and methods', Environmental Science \& Policy 8: 572-8.

Voice, M., Harvey, N. and Walsh, K. (eds) 2006, Vulnerability to Climate Change of Australia's Coastal Zone: Analysis of gaps in methods, data and system thresholds. Part II: Analysis for Costal Zone systems and components, report to the Australian Greenhouse Office, Canberra, June 2006.

Woodruff, R., McMichael, T. and Butler, C. 2006, 'Action on climate change: the health risks of procrastinating', Australian and New Zealand Journal of Public Health 30(6): 460-77. 



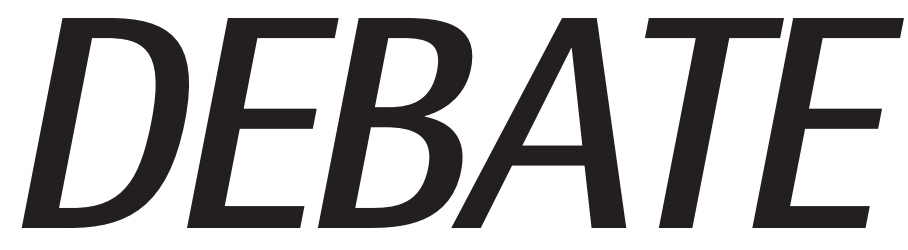





\section{Can Urban Water Markets Work? Some Concerns}

\section{Lin Crase, Suzanne O'Keefe and Brian Dollery ${ }^{1}$}

There is now considerable interest in exploring the usefulness of markets as a means of dealing with urban water provision in Australia. Buoyed by the successes of markets in electricity and telecommunication services, the reformist's gaze has now turned to urban water, where ongoing water shortages have forced water utilities to invoke widespread restrictions to bring demand into balance with limited supply. Amongst the arguments proffered in favour of urban water markets is the view that such arrangements would result in improved allocative efficiency (see, for instance, Productivity Commission 2008). It is also contended that markets should give rise to clear incentives for timely investment in alternative water sources and new technologies which might ultimately alleviate the necessity for water restrictions.

The National Water Initiative (NWI) of 2004 established important actions and objectives to advance water reform. Notwithstanding the subsequent release of the Howard Government's National Plan for Water Security followed by the Rudd Government's Water for the Future manifesto, the work program outlined in the NWI continues to guide policy development, particularly in the area of urban water reform. Paragraph 92 (iv) of the NWI called for a 'review (of) the institutional and regulatory models for achieving integrated urban water cycle planning and management, followed by best practice guidelines' (NWC 2005) and this was later broken into several priority tasks. One of these relates to the requirement to 'facilitate water trading between and within the urban and rural sectors' (NWC 2005). In order to give effect to this and related objectives, a Joint Steering Committee for Water Sensitive Cities was established. The Committee subsequently commissioned several pieces of work to explore the means of introducing water markets in the urban setting.

In a related, but much earlier, development, the introduction of water markets for agricultural water users commenced in earnest in the early 1990s and has clearly yielded substantial economic gains (see, for instance, RIRDC 2007). The capacity of some agricultural industries and/or firms to cushion against the impacts of the recent drought has been substantially enhanced by access to the water market. However, the present operation of rural water markets is likely to vary in significant ways from a potentially atomistic urban water market

\footnotetext{
${ }^{1}$ School of Business, La Trobe University, l.crase@latrobe.edu.au; School of Business, La Trobe University, s.okeefe@latrobe.edu.au; School of Economics, University of New England, bdollery@une.edu.au.
} 
where individual households 'trade' water. In this context, a question arises about the extent to which the perceived successes of the rural water market might be drawn upon as evidence of the merits of similar reforms for urban users, especially households.

In seeking to answer this question it might be helpful to consider those factors that have been important in delivering the economic gains that have flowed from rural water markets. In this regard, it may also be prudent to reflect on some of the well-documented shortcomings of rural water markets (see, for instance, Brennan 2007) to at least temper the policymakers' ostensible enthusiasm for urban water markets. It is thus the purpose of this paper to reflect upon these issues in the hope of informing the policy debate on the potential for water-market reform in urban areas. In essence, the paper presents the case for a cautious approach to urban water markets, particularly where the scope for inter-sectoral trade at the aggregate level has not yet been fully developed.

The paper itself comprises five additional parts. Firstly, we describe the features that have underpinned the success of rural water markets, focusing specifically on what is euphemistically referred to as 'temporary' trade. Second, the limitations revealed during the development of rural water markets are addressed before turning to a comparison of the characteristics of rural and potential urban water-market participants. The penultimate section is used to consider a range of related matters, such as pricing, ownership and institutional design issues. The paper ends by offering some brief concluding remarks.

\section{Successes of rural water markets}

At the outset it needs to be acknowledged that rural water markets are dominated by 'temporary' transactions. In other words, the vast majority of resource re-allocation in irrigation occurs on a seasonal basis and permanent trades, which might be associated with enduring structural adjustment, remain modest by comparison. ${ }^{2}$ Nevertheless, the thriving temporary water market in the southern Murray-Darling Basin is testament to the perceived usefulness of the market for participants (see, for instance, RIRDC 2007).

The motivation for temporary transactions comes from several sources, not least the heterogeneity of farming enterprises and farmers themselves. Put differently, if every farmer was growing the same crop and had relatively similar demands, the scope for trade between parties would be severely limited. It is these marked differences and the potential to bring together enterprises with different calls upon the resource that is critical in this context. After all, this is the premise upon which markets are founded - individuals or groups need to hold valuations and preferences that are so different that exchange can take

\footnotetext{
2 This is particularly the case for permanent interstate trade that has been substantially stymied by the arduous administrative arrangements that attend 'tagging'.
} 
place and the collective gains are more than the costs of bringing about the transaction.

Firstly, the historic allocation of the resource by the state now bears only a weak correlation to the different water demands of enterprises within irrigated agriculture. For example, dairy farming, which can use as much as 10-15ML per hectare, must now compete for water against horticulture cropping which can use half that or less. In addition, the value of the output from these enterprises can also be expected to vary markedly over time, thereby driving demand for re-allocation, albeit often on a temporary basis. Moreover, there are important disparities within enterprises where management expertise heavily influences water use (and profitability). A related feature of this heterogeneity is the differing capacities of market participants to employ substitutes (for example, dairy farmers can substitute grain or silage for water whilst other industries, such as permanent horticulture, cannot). Similarly, some annual enterprises have the option of shutting down completely when water is in short supply, thus affording the opportunity to on-sell any residual water allocations. There are also differences in risk preferences, which can stimulate trade amongst farmers.

Secondly, water is often a vital and substantial input to the production system in irrigated agriculture, at least in volumetric terms. Thus, access at a critical point in the season can represent the difference between a very profitable crop and one that generates substantial losses.

Thirdly, most participants in this market are relatively well-versed with hydrological realities (for example, they know that it will cost money to transfer water uphill and they know the cost of lifting water from an aquifer). These buyers and sellers are also generally familiar with the legislative impediments (or ease) associated with accessing different water sources, such as groundwater - possibly even more so than some regulators.

In a related vein, most of those involved in this market have at least a rudimentary knowledge of the relationship between inputs and outputs. Even the most rustic yeoman would be able to give approximations of the consequences of an extra megalitre of water, here or there, or could roughly calculate the fodder required to substitute for water.

Also, the rural participants in this market face relatively low transaction costs. $^{3}$ The temporary water market has always been keenly promoted by the irrigation sector. In fact, irrigation corporations such as Murray Irrigation Limited and Goulburn-Murray Water have been the champions of the temporary water market and were amongst the first to offer online technologies to facilitate water

\footnotetext{
${ }^{3}$ Unlike the constraints that currently confront someone in a communal irrigation scheme wishing to sell water permanently.
} 
trade. This has not only reduced the transaction costs of farmers who chose to buy and sell water, it has also reduced the costs that would otherwise have to be borne by government to aid in the establishment of the market.

It should be remembered, too, that agricultural participation in this market is sanctioned by government in both a legal and moral sense. There is no innuendo suggesting that trading water between farmers is 'un-Australian'. This observation carries through to the treatment of rural water trade by the press. An agricultural purchaser of water is seldom portrayed as someone draining the life-blood from a desperate seller. This makes the political cost of market participation relatively low for this group.

In important instances the administering organisation charged with physically delivering water between buyer and seller shares much in common with the trading partners. For example, in Victoria, Goulburn-Murray Water, which has responsibility for managing bulk flows to all water users in its area of operation, also has a substantial role in managing irrigation infrastructure for the benefit of farmers.

Finally, participants in the rural temporary water market are generally aware that the long-term entitlements they hold over water are likely to increase in value, in part because of the increasing uncertainty that circumscribes the status of water rights and the volumes of water involved. It can thus be argued that this is one of the major drivers of temporary water trade in the rural water market. In this context it is somewhat ironic that one of the acknowledged weaknesses of the market for permanent water-access rights has simultaneously bolstered participation in the market for temporary trades.

\section{Failings of the rural water market}

It would be foolish to focus solely on the successes of the water market in agriculture (particularly the temporary market) if the ambition is to gain lessons about the potential for urban water markets. If policymakers are seriously considering the usefulness of markets between urban water customers, a balanced view would also draw upon some of the acknowledged failings of Australia's rural water trade.

There is little doubt that the major challenge confronting water markets in Australia has been the underestimated complexity of water-property rights. Commencing with the original decision to validate all sleeper and dozer rights under the Murray-Darling Basin cap-and-trade scheme, legislators have been constantly playing 'catch-up' in an effort to correct one property-right deficiency after another (see, for example, Quiggin 2001). For instance, the rights to return flows from irrigation continue to remain disputed and are largely misunderstood (or ignored) by those promoting the spurious concept of water-use efficiency. Similarly, the failure to account for the connectivity between surface water and 
groundwater with equally stringent regulation has left some jurisdictions with the formidable task of compensating irrigators for the impacts of multiple administrative failures - first, in the over-allocation of surface water and now because of the over-allocation of groundwater.

Defining water rights with precision is difficult enough in the first place, let alone when multiple jurisdictions are continually subject to pressure from various interest groups with a history of substantial use. The net result has been that demands on behalf of environmental interests, which are purportedly protected by legislation, continue to be undermined.

In addition to the major challenges of settling on adequate property rights and related enforcement has been the limited scope of these markets. In many respects this is the corollary of the strengths described earlier. For instance, the fact that most trade has occurred between agriculturists and thereby eased political resistance to the market approach has also constrained the effectiveness of the market to move water to higher-value uses in other sectors. This issue is given greater attention in the following section.

\section{Scope for urban water markets}

One way to analyse the scope for urban water markets is to consider the motivations for rural water trade and make some assessment about the extent to which these forces are likely to hold in an urban setting. We focus primarily upon household users in the first instance.

It has been argued earlier that one of the primary features that led to a flourishing temporary rural water market was the heterogeneity that typifies modern irrigated agriculture. Combined with the critical nature of this resource for some (but not all) irrigated production and the volumes of water involved in a transaction, these are probably the major considerations in the current debate about the potential of urban water markets.

Unlike agricultural water users, the major determinants of water demand for households are family size, size of land allotment and, to some extent, income (see, for instance, Hoffman et al. 2007). Nevertheless, even a cursory assessment of most urban groups would indicate that there are relatively modest welfare gains from trade between households per se compared to that on offer between different agriculturalists. This observation can only be substantiated by empirical research but, prima facie, households face relatively similar demands for water. Most vary between a low of about 100 kilolitres per year and a high of about 400 kilolitres per annum (ABS 2004). Moreover, there is only limited potential for overcoming the constraints imposed on one group of households by transferring water from other households. After all, indoor demand is generally regarded as non-discretionary for all households and is estimated to be equivalent to about 60 per cent of domestic water use (WSAA 2005). Notwithstanding that 
this figure is, in part, a function of water restrictions that ban outdoor use, the extent to which inter-household trade in its own right could alleviate the constraints imposed by water restrictions is limited. ${ }^{4}$

In line with the arguments presented earlier, it is also worth noting the relative knowledge of potential market participants in an urban water market. This issue has several pertinent components. Unlike their agricultural cousins, urban users might be expected to have only a limited appreciation of hydrological constraints and the implications of these for water delivery and pricing. This is not to imply that there are some supernatural powers bestowed on the irrigation fraternity. Rather, the modest use (and cost) of water by urban residents is unlikely to justify the investments in the knowledge required to be able to discern between water products with different hydrological characteristics. ${ }^{5}$ A similar argument may hold for the limited understanding of the production functions for lawns, gardens and the like. It must be emphasised that this should not serve as a criticism of urban water users or act as a justification for lavish public 'education' programs aimed at such users. The reality is that the price and production-related motivation to gain such knowledge is relatively weak for potential participants in a household urban water market.

We contend that unlike household behaviour and demand, the industrial use of water in urban areas is a more complex question, varying with the nature of production, value of outputs and the like. Relatively little research has been undertaken in the area of non-residential urban water use but anecdotally the quality and reliability of supply are more critical to this group than the price of the input per se. Nevertheless, in some cases industrial users will have incentives to gain knowledge and participate in the market that matches or even surpasses that of irrigators. However, the decision by governments to isolate most industrial water users from urban water restrictions has curtailed the incentive to acquire the knowledge and enthusiasm to participate in a market setting. Were a market to be available to this group, it is also difficult to see an industry champion emerging to limit transaction costs, as was the case with the irrigation sector and the activities of Murray Irrigation Limited and Goulburn-Murray Water. In this context, the state would invariably be expected to fulfil this role.

Notwithstanding the limitations facing inter-household trade and the likely necessity for the state to play a major part in fostering participation by industrial users, there remains considerable scope for trade between the household sector as a whole, industrial users who prize ongoing water access and agricultural users. A comparison of the estimated willingness to pay to avoid urban water

\footnotetext{
${ }^{4}$ By way of contrast, irrigators can treat all of their water allocation as discretionary and exit the industry.

${ }^{5}$ Water and wastewater services account for less than one per cent of household expenditure in most states (Edwards 2008: 153).
} 
restrictions with the going rate for temporary rural water allocations in parts of eastern Australia provides some support for this view. For example, Brennan et al. (2006) estimate that the household impacts of water restrictions are between $\$ 347$ and \$870 per season in Perth. In a similar vein, Hensher et al. (2006) report a household willingness to pay $\$ 239$ per year to avoid water restrictions. To provide a rough basis for comparison, it is worth noting that in 2004/05 Australian households consumed on average 103 kilolitres per capita in total. This equates to about 300 kilolitres for an average three-person household or less than a third of one megalitre of water. By way of contrast, the going rate for temporary access to a megalitre of 'raw' water currently stands at about $\$ 300$ (see, for example, Watermove 2008), although this varies across the irrigation season. Even after accounting for the additional cost of converting raw water to potable water, there should be ample scope for alleviating or lowering water restrictions by trading water away from agriculture into urban areas.

Similar support can be found in the outcomes from a recent inter-sectoral water-trading program in Northern Victoria. In this case, commercial urban users and larger water users responsible for managing community sporting assets (such as bowling clubs, tennis clubs, schools and the like) were afforded the opportunity to enter the temporary rural water market and 'trade their way out of water restrictions'. The popularity of this program and the willingness of participants to pay standard delivery charges on top of the cost of the bulk water purchased are indicative of the potential benefits of inter-sectoral trading activity. Regrettably, few similar cases of trade at this level are available, at least to the knowledge of the authors.

Of course, all water trades are contingent on some form of interconnection between users. There is some doubt that this will ever be feasible for all jurisdictions. For instance, Victoria already enjoys interconnection between different sectors and the planned north-south pipeline should expand this 'grid' of connectivity. By way of contrast, the scope for interconnectivity between agricultural water users and the urban residents of Sydney seems remote in the context of current water prices. The point here is that any program of reform adopted on a national scale should at least consider this most rudimentary principle. ${ }^{6}$ There seems little point in insisting on national standards for inter-sectoral trade where interconnection is never likely to be feasible in some jurisdictions.

In addition to physical connectivity, two additional conditions need to be met to ensure the operation of the urban-rural trade. First, trade between sectors

\footnotetext{
${ }^{6}$ It can be argued that the reluctance of Tasmania and Western Australia to become signatories to the National Water Initiative hinged partly on the irrelevance of sections of the reform package to these jurisdictions. For example, nationally consistent water entitlements will count for little in Tasmania until a cheap means of exporting water to the mainland is discovered.
} 
needs to be politically acceptable or run the risk of stalling. Second, the institutions charged with actually delivering water to purchasers must have sufficient incentives to honour such trades. Regrettably, both of these conditions remain as significant obstacles in some states. Water traded to urban users from willing agricultural sellers continues to be described in the press as 'taking water' and dubious water-for-infrastructure swaps are put in place to appease those who claim to be disaffected (see, for example, DSE 2008). In some jurisdictions the function of bulk water delivery has yet to be adequately separated from agricultural interests, resulting in inequitable treatment of water users regardless of the status of validly purchased water access rights.

\section{Other market issues}

Accompanying the discussion about urban water trade are a range of arguments that focus on urban water pricing. Popular in this context are calls for the use of 'scarcity pricing' to replace urban water restrictions (see, for instance, Grafton and Kompas 2007). The basic idea is that water prices should be permitted to vary in the short term to reflect the relative scarcity of the resource. Accordingly, higher prices would help choke off demand, rather than relying on punitive restrictions which impose welfare costs. In addition, the higher prices would act as a clearer incentive to drive investments in alternative infrastructure.

These arguments would have greatest credibility if genuine and complete inter-sectoral access to the available resources had been achieved or where inter-sectoral transfers are not feasible at all. Put simply, the welfare gains from scarcity pricing are likely to be severely limited unless, in the first instance, wholesale scarcity is addressed using the most cost-effective alternatives. For those jurisdictions with the opportunity for inter-sectoral trade, focusing on scarcity pricing at the household level has the potential to divert attention from the substantive gains on offer from higher-level reform. Where sectoral connectivity is problematic, clearly scarcity pricing has a more useful role ${ }^{7}$ and should be pursued.

A second strand of arguments about urban water trade centres on the institutional design of a competitive water industry and the role of the private sector within this regime. Notwithstanding the intuitive appeal of competition, most of these questions require empirics to guide decision-makers. In addition, much of this analysis needs to be undertaken on a jurisdiction-by-jurisdiction basis, since results from these types of studies are heavily influenced by geographical variations. To the best of our knowledge, very little empirical work

\footnotetext{
${ }^{7}$ It is worth noting the Grafton and Kompas (2007) show that scarcity pricing in Sydney would obviate the need for water restrictions, but that the city would still confront critical water shortages without significant augmentation works.
} 
is available at this scale to guide the discussion and a great deal more work should be undertaken as part of settling on a national reform agenda in this field.

\section{Concluding remarks}

Urban water markets are clearly part of the wider Australian water-reform agenda. The mounting enthusiasm for urban water markets can be traced to at least two sources - the broad success of urban-utility reform in other sectors and the accomplishments of the rural water market. This paper has focused primarily on the latter of these motivations. In essence, we have argued that many of the features that have buttressed the success of rural water markets are absent from a potential household-to-household water market. Nevertheless, there is unquestionably scope for markets in the context of wider inter-sectoral redistribution of the resource and this should be regarded as the 'low-hanging fruit' $^{\prime}$ in the water-reform orchard of some jurisdictions.

In addition, the experience with rural water markets gives some indication of the challenges associated with property rights and the political and institutional changes that would be required to support an urban water market. It would be unwise to underestimate the magnitude of these problems.

Modifications to urban water pricing also has merit, but this should not be considered in isolation. Overcoming the Balkanised approach to different water users (Freebairn 2005) should be the major focus of immediate reform. Similarly, there are a range of industry design issues ranging from the extent of private-sector involvement to the level of competition at different stages of the supply chain. In this instance, decisions should be based on sound empirical understanding and an appreciation of political realities. Regrettably, the latter tend to be in more plentiful supply than the former when it comes to urban water reform.

\section{References}

ABS 2004, 'Water Account, Australia', Canberra, Australian Bureau of Statistics.

Brennan, D. 2006, 'Water policy reform in Australia: Lessons from the Victorian seasonal water market', Australian Journal of Agricultural and Resource Economics 50(3): 403-23.

Brennan, D., Tapsuwan, S. and Ingram, G. 2007, 'The welfare costs of urban outdoor water restrictions', Australian Journal of Agricultural and Resource Economics 51(3): 243-62.

DSE 2008, 'Protecting the food bowl's future', Melbourne, Department of Sustainability and Environment. 
Edwards, G. 'Urban water management', in L. Crase, (ed.) Water policy in Australia: The impact of change and uncertainty, Resources for the Future Press, Washington.

Freebairn, J. 2005, 'Early Days with water markets', Industry Economic Conference. Melbourne.

Grafton, Q. and Kompas, T. 2007, 'Pricing Sydney Water', Australian Journal of Agricultural and Resource Economics 51(3): 227-42.

Hensher, D., Shore, N. and Train, K. 2006, 'Water supply security and willingness to pay to avoid drought restrictions', Economic Record 82(256): 56-66.

Hoffmann, M., Worthington, A. and Higgs, H. 2006, 'Urban water demand with fixed volumetric charging in a large municipality: The case of Brisbane, Australia', Australian Journal of Agricultural and Resource Economics 50: 347-59.

Musgrave, W. 2007, 'Historical Development of Water Resources in Australia: Irrigation in the Murray-Darling Basin', in Crase (ed.) op. cit.: 28-43.

National Water Commission 2005, 'Overview of the National Water Initiative', Canberra, National Water Commission. Available at: http://www.nwc.gov.au/nwi/index.cfm\#trading

PC 2008, 'Towards urban water reform: A discussion paper', Melbourne, Productivity Commission.

Quiggin, J. 2001, 'Environmental economics and the Murray-Darling river system', Australian Journal of Agricultural and Resource Economics 45(1): 67-94.

RIRDC 2007, 'The economic and social impacts of water trading: Case studies in the Victorian Murray Valley', Canberra, Rural Industries Research and Development Corporation. 


\title{
Can Urban Water Markets Work? An Optimistic View
}

\author{
Hugh Sibly ${ }^{1}$
}

Until recently there has been a common perception that urban water provision is a natural monopoly and, as such, must either be government-owned business, highly regulated, or both. Since the mid 1990s the urban water authorities have been run as a corporatised (state or local) government business, regulated by a state government regulator using traditional price caps and rate-of-return regulation. ${ }^{2}$ However, it has become apparent over recent years that the urban water sector is not as efficient as it might be. Thus there has been a growing acceptance that there is some scope for the introduction of competitive urban water markets.

In their paper, Crase, O'Keefe and Dollery (2008) correctly observe that there are two catalysts for growing enthusiasm for the development of urban water markets: (i) success in rural water markets and (ii) success in other utility reforms. They focus on the former, and argue that the preconditions for success in the rural water markets are not present in the urban water sector. They thus present a somewhat pessimistic view of the prospects for urban water reform.

In contrast, this paper considers reform of the urban water sector from the point of view of 'utility reform'. This is worth considering, in conjunction with Crase, O'Keefe and Dollery's arguments, because all utilities are 'network' industries. For instance, the value chain in an urban water network is in many respects qualitatively similar to an electricity network (though clearly the technicalities of the engineering are very different). In particular, water (electricity) is supplied to consumers through a water network (grid) by a bulk water supplier (generator). Thus common issues arise, relating to the efficiency of their operation, across different types of utilities.

Because urban water is a network industry, an urban water market would look different from the existing rural water markets. In rural water markets, participants exchange their entitlements at a market-clearing price until they exhaust all gains to trade. Entitlements are diffuse and a participant's role as either a buyer or seller may change across seasons. In the urban water sector there are a relatively small number of sources (which are always suppliers) supplying a large number of consumers (who are always buyers) connected by

\footnotetext{
${ }^{1}$ School of Economics and Finance, University of Tasmania, hsibly@postoffice.utas.edu.au

${ }^{2}$ Water bills usually include a volumetric and fixed charge. Regulators set the fixed charge to ensure that a water authority makes a target rate of return.
} 
a common network. Nonetheless, in both rural and urban water sectors the efficient allocation of water can only occur if participants face an efficient price. It is agued below that urban water allocation in Australian cities is particularly inefficient because the current regulatory framework has not set the efficient price for water. Introducing competitive urban water markets represents the best option for establishing an efficient price and thereby an efficient (least-cost) urban water sector.

This paper therefore presents an optimistic view of the prospects for urban water reform. It does so by first arguing that the current performance of the urban sector is quite poor. Using this analysis, a case is made for the introduction of urban water markets in Australian cities. Some options for the introduction of competition into the urban water sector are then canvassed. The final section considers potential impediments to the proposals to implement urban water markets discussed earlier in the paper.

\section{State of Play: Politicisation}

When one asks whether urban water markets will work, one must also ask 'work relative to what?' The implicit assumption is often that the current 'command and control' regime is working satisfactorily. This is not the case. There are no commercial or management decisions made by water authorities that are not politicised. This has resulted in significant distortions of the urban water market in Australia.

There are three sources of distortion in Australian urban water provision. First, price signals for urban water are almost completely absent (Sibly 2006a). This absence is in spite of the fact that any increase in the volumetric rate would only increase the bills of high users. This is because a water authority's charges are regulated so as to satisfy a revenue-raising requirement. Thus an increase in the volumetric rate should be accompanied by a corresponding reduction in the fixed charge. Equity issues could be addressed by providing rebates on the fixed charge for the disadvantaged.

The resultant price inflexibility results in rationing ('water restrictions') as a ubiquitous response to drought. Water restrictions cause a loss of allocative efficiency (see, for example, Sibly 2006b). The extent of this cost has only recently become apparent. Grafton and Ward (2008a) estimate the cost of water restrictions in Sydney, and find this is a little less than half the household water bill. This is consistent with Brennan et al.'s (2007) finding that households would pay between $\$ 374$ and $\$ 870$ per season to avoid water restrictions. Mansur and Olmstead (2007) estimate the efficiency loss from a two-day-per-week watering restriction used in 11 urban regions in the US and Canada. They found that this one restriction caused an efficiency loss equal to a quarter of the household's 
water bill. ${ }^{3}$ Thus, as setting a market-clearing price for water yields the same allocation as water trading, Crase, O'Keefe and Dollery's view that "there are relatively modest welfare gains from trade between households per se" does not appear to be correct. ${ }^{4}$

Increasing block tariffs (IBTs) are the second distortion created by the politicisation of the urban water market. Instead of implementing an efficient (flexible) volumetric rate in response to the current drought, state regulators have implemented IBTs. While the implementation of IBTs is often portrayed as a 'price response' to the drought, they are better described as a political response to the drought. IBTs are easy to justify politically, because their implementation is aimed at 'water hogs'. In Australia, the tiers of the IBTs are set so as to insulate the typical consumers from facing the cost of decreased availability of water. In fact, volumetric rates (at the margin) for most consumers have varied very little over the course of the drought. Hence, the implementation of IBTs give the illusion of a response to decreased availability without actually delivering the required increase in the volumetric rate to most consumers. Thus IBTs are a contributing source of the current allocative inefficiency in Australian urban water provision (Sibly 2006a). Recognition of the inefficiency of IBTs has caused the National Water Commission to call for their replacement with a flat 'scarcity price' of water (National Water Commission 2008).

The third distortion created under the current regime is the underinvestment, or inappropriate investment, in infrastructure. Urban water-infrastructure developments are highly controversial, being the subject of much ill-informed and ideological discussion. The resultant political decision-making is likely to be excessively risk averse. With such obstacles to planning infrastructure development, efficient projects are likely to be subject to costly delays or even replaced with less-efficient projects. There are many examples of this process. As a result of the Toowoomba referendum, ${ }^{5}$ the relatively cheap recycling option was replaced by a relatively expensive option to build a $40 \mathrm{~km}$ pipeline to pump water up from Wivenhoe Dam. The cost of this relatively expensive option will presumably be carried by the Queensland taxpayer rather than solely by those who voted for it. Similarly, following years of indecision on how best to augment the Sydney water supply, a decision to build a desalination plant was made in 2007. Grafton and Ward (2008b) have argued that the desalination plant under construction for Sydney could have been delayed for many years if flexible pricing had been used (an option which is apparently never considered when

\footnotetext{
3 The efficiency loss is measured relative to the case in which price is used to curb demand by an equivalent amount.

4 To realise these gains the institution framework must be one in which there are relatively low transaction costs. See the proposals below.

${ }^{5}$ In July 2006, a 62 per cent 'No' vote was recorded in the City of Toowoomba's referendum on recycling 'waste water' (sewage) as drinking water.
} 
making such decisions). They estimate the expected cost of these inefficient policies to be more than $\$ 1$ billion. Given these and other similar events, it is difficult to believe that the current planning regimes yield an optimal investment in urban water infrastructure.

\section{Why introduce urban water markets?}

The ubiquitous use of restrictions, the introduction of IBTs and poor investment in infrastructure reflect significant shortcomings in the current regulatory and planning framework. There is clearly scope for reforms that would improve the performance of this industry. Central to any such reform of the water industry must be an implementation of an efficient volumetric rate for water.

In order to achieve an efficient (or least-cost) provision of urban water it is necessary for consumers to face an efficient volumetric rate. Allocative efficiency can only be guaranteed by having an efficient volumetric rate. This rate clears the market in each period and thus there is no need for costly water restrictions. An efficient volumetric rate must reflect not only the current availability but also the expected availability of water (Sibly 2006a). Australia's erratic rainfall patterns mean that large storages are needed if cities are to be provided with water from surface water. The efficient volumetric rate generates an efficient inter-temporal allocation of water, and thus the optimal storage at each time. An efficient volumetric rate is also needed to assess the efficient type and timing of infrastructure investment.

Australian water markets are not likely to be static. Future climate variability and unexpected demographic changes will require frequent adjustments to the operations of urban water markets. As well as being subject to the distortions described above, the current arrangements do not exhibit sufficient flexibility to adapt efficiently to changing circumstances. The natural inclination of economists would be to introduce competitive markets for urban water. Competitive markets are (unlike the current arrangements) self-correcting mechanisms. They ensure that all market participants face to true costs and benefits of their actions, and thus provide market participants with appropriate incentives to develop innovations. A competitive market would be distanced from the political process, and therefore not subject to the distortions described above. However, a competitive market requires a substantial number of suppliers. The following section considers proposals about how this could be achieved.

It might be wondered whether the current arrangement of a regulated urban water monopoly overseen by a regulator could be modified to overcome the problems identified above. For instance, perhaps it is possible to enhance the independence of state-based regulators, and ensure they are distanced from political pressures. The independence from the political process of the Reserve Bank's interest-rate decisions could be a model for this type of institution. Such 
a regulator would be charged with setting the optimal scarcity price for the monopoly supplier. No doubt this reform would result in an improved performance of urban water authorities.

However, there are limitations to the ability of regulation to enhance efficiency, even in the absence of political pressures on decision-making. Markets have the ability to aggregate decentralised, diffuse information in a way that regulators cannot. Regulated industries, particularly those facing price caps and rate-of-return regulation, have a poor incentive to innovate because they often cannot capture the full returns to their innovation. As noted above, the ability to respond flexibly to change is likely to be of increasing importance in providing urban water to Australian cities. Regulation is thus an inferior option to competition, provided competition is feasible. The question therefore becomes whether it is realistic to introduce a competitive market for water in Australia cities and, if so, how this is best done.

\section{Implementing urban water markets}

In order to discuss whether urban water markets can work, it is necessary to consider the institutional framework in which the proposed markets will operate. Worldwide, there have to date only been tentative reforms directed at introducing competition. While these reforms will increase flexibility and efficiency, they only address partially the above problems.

In Australia, Part IIIA of the Trade Practices Act allows for third-party access to an urban water networks, provided a 'declaration' of that service is made. So far only one such declaration has been sought - by Services Sydney in 2004 trying to gain access to the sewerage infrastructure of Sydney Water. This access was resisted by both Sydney Water and the New South Wales premier. This ultimately led to the development of the NSW Water Industry Competition Act (2006), which regulates third-party access to urban water infrastructure in the Sydney and Hunter regions. More recently, the ACCC has made a determination on the methodology used to set access prices to water infrastructure (for a detailed discussion of these issues, see Gray and Gardner 2008). To date, no third-party access to urban water networks has occurred in Australia.

In the UK the Water Act (2003) allowed the implementation of the current 'Water Supply Licensing' regime. This regime (like that in Australia) has not, to date, produced significant competition in UK water supplies. The UK water regulator, Ofwat, identifies the current cost of access, including current access, as the reason for this (Ofwat 2007). Ofwat has recommended changes to the way in which the urban water industry is structured so as to increase the level of competition. In particular, it argues for a separation of contestable from non-contestable markets (sewerage and retail sectors are specifically identified) 
and the development of new market models for upstream competition (Ofwat 2008: 8).

Sibly and Tooth (forthcoming) and Young, McColl and Fisher (2006) propose methods by which the role of urban water markets could be expanded in Australia. These proposals involve, to some extent, a decoupling of water and network ownership (as do all that suggest the implementation of competition). Young, McColl and Fisher (2006) propose a model in which the market is supplied by a monopoly water authority, but one which allows trading between its customers. To generate urban water trading, they suggest allocating each household a tradable allowance of 200 kilolitres per annum. Households would need to purchase additional water to consume beyond that limit and could sell any unused allocation. Water use beyond $200 \mathrm{kl} / \mathrm{yr}$ could be regulated by (i) a scarcity price or (ii) a cap-and-trade system. Young, McColl and Fisher propose that the scarcity price would be related to dam levels. If such a price were regulated, it need not necessarily be set at the market clearing level. In this event, water restrictions would remain necessary. In the cap-and-trade system a limit on total water consumption above $200 \mathrm{kl} /$ year/household would be set, and households could bid for a share of the available water. Such a process would eliminate excess demand for water, and thus could eliminate water restrictions. However, to ensure the efficient inter-temporal allocation of water (storage) the cap must be set appropriately in each period.

Sibly and Tooth (forthcoming) propose a more comprehensive change in the way urban water markets function, with an aim to introduce competition at every point in the value chain. In particular, their proposal removes the presence of the monopoly water supplier. It suggests that private parties, so-called virtual water suppliers, be given the right to own the water stock held in dams. New inflows into the storages are proposed to be periodically auctioned off to these private water owners. Virtual suppliers compete with one another in the provision of bulk water. The implementation of this proposal, when combined with effective third-party access to urban water networks, would lead to a competitive bulk water market. Retailers would coordinate the supply of bulk water in each period with consumer demand. Entry into the retail market would have relatively low costs. Thus the retail market would also be competitive. In this way the volumetric price would be efficient at every point in the value chain, giving all market participants appropriate price signals. Note that under these arrangements consumers need only negotiate supply with retailers, and do not require the hydrological expertise of the participants in rural water markets.

Introducing competition in urban water markets, as proposed by Ofwat, Young, McColl and Fisher, or Sibly and Tooth has not been attempted before. It may be advisable to introduce these reforms gradually, so that unforeseen 
difficulties can be identified early before they cause too much disruption. Indeed, Ofwat (2008) presents a timetable for the gradual introduction of competition into UK urban water markets. Similarly, a variant on the Sibly and Tooth approach would be to allow some limited private ownership of stored water in parallel with the existing allocation system. The role of the private market could be expanded gradually over time, until eventually all urban water was traded on an open market.

\section{Discussion}

This paper has argued that the implementation of urban markets would substantially improve the performance of the urban water sector. It is true that many of these reforms have not been attempted before. However, reform of this sector is more urgent in Australia than elsewhere because of forthcoming climate variation and demographic change. Australia's climate is likely to vary, whether this is due to anthropogenic climate change or just natural variations in weather patterns. Australia needs an urban water sector that can rapidly and efficiently adjust to such changes more than most countries. Similarly, demographic changes and industrial structural adjustment mean changes in water demand. The current regime has not proved capable of dealing with this. Opening up water networks to competition will provide incentives for all market participants to adjust efficiently to the myriad changes ahead. The alternative would appear to be lurching from water crisis to water crisis.

The greatest impediment to the implementation of competitive urban water markets is inappropriate or inadequate regulatory reform. If water markets are to be introduced effectively prospective participants must have unencumbered access to either water or infrastructure. There cannot be artificial obstacles (legal or bureaucratic) to entry that increase the cost of access. If this is not the case then incumbents (such as existing water utilities) will be given excessive market power, and this will limit the gains from introducing water markets. ${ }^{6}$

Any reform must also deal with past poor infrastructure decisions. If, for example, the desalination plant in Sydney indeed turned out to be a high-cost bulk water source, its market value would be much lower in a competitive urban market than its capital cost. In this environment, if the NSW government were either to sell it or contract out its operations it would make a considerable paper 'loss' on the transaction. There is a danger the government might try to prop it up and such actions might have the effect of interfering with the efficient operation of the urban market.

${ }^{6}$ For instance, the costs and delays that Services Sydney faced in gaining access to Sydney Water's infrastructure represent a significant barrier to entry. If these costs and delays remain, they will deter many prospective entrants, and thereby decrease the competitiveness of any future market. 
Similarly, Crase, O'Keefe and Dollery are correct in arguing that in any reform to create an urban water market the government must resolve the issue of interconnectivity of the rural and urban water sectors. Rural water is almost certainly the cheapest available source of new water for urban areas. Many prospective bulk water projects could not compete with the relatively inexpensive water from rural sources. However, the issue here is a failure of government to provide the appropriate regulatory framework to establish interconnectivity between markets, not that urban water markets cannot work.

\section{References}

Grafton, Q. and Ward, M. 2008a, 'Prices versus Rationing: Marshallian Surplus and Mandatory Water Restrictions', Economic Record 84, September: S57-65.

Grafton, Q. and Ward, M. 2008b, 'So much money down the drain', Sydney Morning Herald, 18 July; available at: http://www.smh.com.au/news/ water-issues/so-much-money-down-the-drain/2008/07/17/1216163057654.html

Gray, J. and Gardner, A. 2008, 'Exploiting the unspeakable: Third-party access to sewage and public-sector sewerage infrastructure' in Troy, P. (ed.), Troubled waters: confronting the water crisis in Australia's cities, ANU E Press, Canberra; available at: http://epress.anu.edu.au/troubled_waters_citation.html

Mansur, E. T. and Olmstead, S. M. 2006, 'The Value of Scarce Water: Measuring the Inefficiency of Municipal Regulations', NBER Working Paper No. 13513, October.

NWI Steering Group on Water Charges 2007, 'Water Storage and Delivery Charges in the Urban Water Sector in Australia', February; available at: http://www.nwc.gov.au/nwi/docs/UrbanWaterChargingStocktake_Feb\%2021.pdf, downloaded March 2007.

National Water Commission 2008, ‘Urban Water Pricing: National Water Commission position'; available at:

http://www.nwc.gov.au/resources/documents/UrbanWaterPricing_PS-0708.pdf

Ofwat 2007, 'Market competition in the water and sewerage industries in England and Wales, Part One: Water Supply Licensing'; available at:

http://www.ofwat.gov.uk/aptrix/ofwat/publish.nsf/AttachmentsByTitle/ marketcomp_waterind_part1.pdf/\$FILE/marketcomp_waterind_part1.pdf

Ofwat 2008, 'Ofwat's review of competition in the water and sewerage industries: Part ll'; available at: http://www.ofwat.gov.uk/aptrix/ofwat/publish.nsf/ AttachmentsByTitle/pap_rsh_reviewmrktcomp.pdf/\$FILE/pap_rsh_ reviewmrktcomp.pdf

Sibly, H. 2006a, 'Urban Water Pricing', Agenda 13(1): 17-30. 
Sibly, H. 2006b, 'Efficient Urban Water Pricing', Australian Economic Review 39(2): 227-37.

Sibly, $\mathrm{H}$ and Tooth, R. (forthcoming), 'Bringing Competition to Urban Water Supply', Australian Journal of Agricultural and Resource Economics.

Young, M., McColl, J. and Fisher, T. 2007, 'Urban water pricing: How might an urban water trading scheme work?', Droplet 5, University of Adelaide, February. 

CONTROVERSY

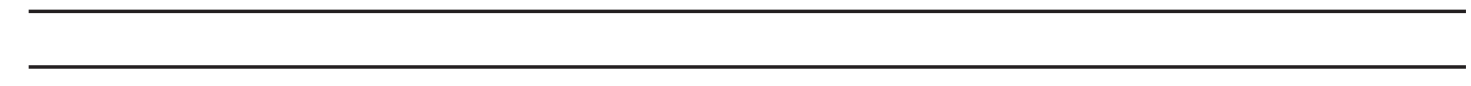





\section{Is policy the problem or the solution for Indigenous people? A Rejoinder to Gary Johns}

\section{Boyd Hunter ${ }^{1}$}

In my paper entitled 'Conspicuous Compassion and Wicked Problems: The Howard Government's National Emergency in Indigenous Affairs' (Hunter 2007a) in a recent issue of Agenda, the reference to 'wicked problems' was an attempt to extend the debate over 'the intervention' by drawing on the theorising in public policy about appropriate responses to complex, multi-dimensional problems; problems which are intrinsically hard to define because multiple stakeholders have differing perspectives on what the underlying problem is: 'wicked problems' (see also Commonwealth of Australia 2007).

In the last issue of Agenda Gary Johns (2008) asked whether the underlying cause of Indigenous disadvantage in the Northern Territory is a 'wicked problem' or the result of 'wicked policy' of 'self-determination'. Johns argues that Indigenous disadvantage can only be solved by changing the system of government support and infrastructure so that people face the true costs of their decision to stay in remote communities - that is, to encourage mobility to more buoyant labour markets where jobs are available. More generally, Johns argues for a policy of 'economic integration', on the grounds that the modernisation project is (necessarily) inconsistent with cultural maintenance.

One problem with Johns' argument is that it ignores some of the difficulties that Indigenous workers have in securing jobs in urban labour markets. One important constraint in this regard may be the existence of ongoing labour-market discrimination (Hunter 2005). Another issue is the mismatch between the skills demanded by employers and the skill set that Indigenous people currently have.

Further, while I allow - and raised in my paper - the prospect that there is some partial inconsistency, or trade-off, between modernisation and cultural maintenance, I believe that the extent of such a trade-off is an empirical question. Granted, it is possible to argue that maintaining a cultural identity that is distinct from the mainstream Australian norms might foreclose some employment and education options. However, the evidence seems to indicate that such fears can be overstated. For example, Hunter (2007b) shows that youth who speak an Indigenous language are actually more likely to attend school.

\footnotetext{
${ }^{1}$ Centre for Aboriginal Economic Policy Research, The Australian National University, Boyd.Hunter@anu.edu.au
} 
The policy 'take-away' of Johns' paper is a radical change in the set of incentives for mobility facing Indigenous people: the removal of unconditional income support and services provided in such communities by Community Development Employment Projects (CDEP) schemes or other government initiatives. The optimal level of mobility depends on both the individual and the social costs and benefits of moving. Even if one is willing to ignore Indigenous perspectives on culture and interventions made on their behalf, it is not entirely clear to me that mobility will necessarily result in the benefits anticipated by Johns - especially when one takes into account the likelihood that there will be substantial short-run adjustment costs (for example, in social dislocation) and the difficulty that many Indigenous people have in securing employment in complex labour markets.

Another factor that is discounted in Johns' analysis is that the ongoing existence of an authentic and living Indigenous culture has a considerable market and non-market value to both Indigenous and non-Indigenous Australians. From a national perspective, CDEP jobs are also important for much of the natural-resource management work undertaken in remote Australia. For example, Indigenous Protected Areas are an integral part of the conservation estate, and ensuring that such areas are adequately maintained is in the national interest.

One aspect of Johns' argument that I do agree with is that the CDEP scheme supports the existence of remote Indigenous communities that might not continue to exist if all government support were withdrawn. In that sense, the CDEP scheme provides tangible support to Indigenous culture in such areas. Furthermore, as I argue elsewhere (Hunter 2008), mainstream (non-CDEP) jobs provide more protection against entrenched Indigenous disadvantage than CDEP scheme jobs. Consequently, one can argue that there is, in a sense, a trade-off between cultural maintenance (which is clearly supported by the CDEP scheme) and other important socioeconomic dimensions of Indigenous social exclusion.

Hence, whatever one's positions on the validity of the arguments put forward in our respective papers, I believe public debate would be enhanced by the further evaluation of the extent of trade-off between cultural maintenance and integration into the mainstream economy. The main impediment for this research agenda is that 'culture' is a difficult, if not impossible, concept to define and measure - notwithstanding that this trade-off is a central issue which continues to divide the respective protagonists in this debate.

From my perspective, one of the major weaknesses with the intervention was that it did not incorporate a transparent evaluation framework. Hence there is no way to adequately evaluate the outcomes or attribute them to this or any other policy initiatives. The lack of an adequate pre-existing benchmark is even more evident for evaluating the policy of 'self-determination', as the quality of Indigenous data was even more dubious in the early 1970s. No major change in 
policy would be enacted in the United States without putting in place a strategy for evaluating the outcomes - many US policy initiatives even incorporate social experiments (with random assignment) into their original design. It is time that Australia considered doing the same.

In summary, my main criticism of Johns (2008) is that he ignores the aspects of Indigenous disadvantage that make it a wicked problem. Policy cannot be drawn up without proper consultation with the people affected by the policy. The fact that some of the people targeted by the NT intervention have a different perspective from that of policymakers is likely to increase their resistance to the implementation of that policy. However, if policy is not designed to take into account, or is otherwise adapted to, the current behaviour and preferences of the target population, then it should be acknowledged that such policies may perpetuate the underlying problems. That is, policy can simultaneously be both part of the problem and part of the solution.

\section{References}

Commonwealth of Australia 2007, 'Tackling Wicked Problems: A Public Policy Perspective', Australian Public Service Commission, Canberra.

Hunter, B. H. 2005, 'The role of discrimination and the exclusion of Indigenous people from the labour market' in D. Austin-Broos and G. Macdonald (eds), Culture, Economy and Governance in Aboriginal Australia, University of Sydney Press, Sydney.

Hunter, B. H. 2007a, 'Conspicuous Compassion and Wicked Problems: The Howard Government's National Emergency in Indigenous Affairs', Agenda 14(3): 35-54.

Hunter, B. H. 2007b, 'Cumulative Causation and the Productivity Commission's Framework for Overcoming Indigenous Disadvantage', Australian Journal of Labour Economics 10(3): 185-202.

Hunter, B. H. 2008, 'A half hearted defence of CDEP scheme', a seminar presented in the CAEPR series on 12 March 2008; available at: http://www.anu.edu.au/caepr

Johns, G. 2008, 'The Northern Territory Intervention in Aboriginal Affairs: Wicked Problem or Wicked Policy?', Agenda 14(3): 65-84. 

REIROSPECT

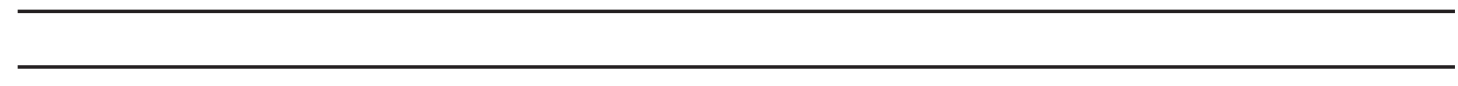





\section{Dave Clark (1946-2008): Economist, Larrikin, 'Critical Drinker' and Friend}

\section{Peter Groenewegen ${ }^{1}$ and John Lodewijks ${ }^{2}$}

David Leonard Clark - teacher, raconteur, splendid host and sociable drinker, fine historian and solid intellect - died unexpectedly, at the relatively young age of 61, on 27 May 2008. His like is not easily discovered in our generation.

Dave was born on 3 August 1946 and spent much of his youth on Sydney's beaches and waterways, and later paid for it with melanoma. He matriculated from Sydney Technical High School (1963), already with a reputation as a 'rebel'. In 1968 he completed a First Class Honours degree in Economics from the University of Sydney; his fellow honours students included John Hewson and Nick Greiner. David came first in the History of Economic Thought class at the University, gaining the prize, and writing a thesis (or long essay) which was the best the first author had read that far in his teaching career. Clark's honours thesis was published (Clark 1978) as 'Worse than Physic: Sydney's Water Supply 1788-1888', in a book of essays on nineteenth-century urban history. This early research showed Dave's willingness to 'dirty his hands' by studying 'the facts' buried in the archives, and prepared him well for his later articles on economic history for the Australian Encyclopaedia. It also showed his credentials as a fine economic historian.

Dave's interest in the history of economic thought, together with his equally strong interest in economic theory, stimulated him to research a $\mathrm{PhD}$ on the theories of economic growth and development from 1925 to 1950 . He thereby became Peter Groenewegen's first PhD student, and lifelong friend. The saga of Dave's PhD was a longish one, as the thesis topic grew broader with time. In the end, it covered input-output analysis (and its roots in Quesnay's Tableau économique and Marx's reproduction models), the 1930s capital controversies, institutionalist critics of the literature (including those from the Kiel School), as well as precursors of the Harrod-Domar growth models. Articles from the thesis, on 'Lowe's Contribution to Capital and Growth Theory' (Clark 1984a) and 'On the Origins of Growth and Planning Theory' (Clark 1984b), subsequently appeared in journals. Thereafter, Dave rarely troubled journal editors. Perhaps, as is the case with many academics with highly critical faculties, he was never fully satisfied with his own work. In later years, he thought his energies would

\footnotetext{
${ }^{1}$ Discipline of Economics, Faculty of Economics and Business, University of Sydney, peter.groenewegen7@bigpond.com

2 School of Economics and Finance, University of Western Sydney, J.Lodewijks@uws.edu.au
} 
be better placed in writing for a larger public audience than for scholarly journals that no one read.

On the strength of the PhD research Dave Clark gained post-doctoral research experience at Cambridge and Leuven (Université Catholique de Louvain). Among other things, his sojourn in Leuven gave him a taste for Belgian beer. From the late 1970s, he also enjoyed wine-purchasing expeditions in the Hunter Valley and Mudgee. Dave therefore appreciated good reds as well as beer, and did so with gusto. He had a palate for a fine shiraz, of which we enjoyed many a bottle at parties, BBQs or good BYO restaurants. Dave may have been a latecomer to the Sydney Push, but was nevertheless a 'critical drinker' of the first rank, as well as a staunch reader of Broadsheet, ${ }^{3}$ and its successor Heraclites. His politics were libertarian in essence, explaining his enduring close friendship with Jack Grancharoff, a Bulgarian anarchist émigré whose experience in Australia began as a worker on the Snowy Mountains Scheme. As a student, Dave had been very active in the anti-war Vietnam movement, participating in dozens of 'demos' and getting arrested occasionally for his enthusiastic involvement in the cause. 'Fight the good fight' came easy to Dave as a quality which endured.

Dave was magnificent in the bitter Political Economy (PE) dispute which plagued the University of Sydney's economics department for much of the 1970s and early 1980s. He vigorously criticised the PE teachers as 'left-wing infantilists' whose knowledge of radical economics left much to be desired, and whose knowledge of the Australian situation and economic history, generally speaking, was dismal - as dismal as the science they were criticising.

A little earlier, upon the expiry of his Commonwealth postgraduate scholarship, Dave was appointed to a lectureship in the School of Economics at the University of New South Wales in 1971, and promoted to a senior lectureship in 1978. His teaching was very diverse. In 1984, for example, he taught courses on 'Australia in the International Economy' and 'Marx to Keynes'; by 1989 he had added courses on 'Australian Economic Development in the $20^{\text {th }}$ century' (also a topic for a book never finished), as well as Soviet and Australian economic history.

He was associated with the University of NSW for 35 years, and for much of that time he was part of a group of economic historians who were exceedingly productive, colourful and continually engaged in one-upmanship. The only thing that unified this diverse set of egos was their common loathing for the professor and head of their department. Dave's failure to be promoted beyond Senior Lecturer (deplored as a major scandal by Bruce McFarlane at the funeral oration) led to his increasing disillusionment with academia. His favourite saying about universities was that 'university politics are vicious precisely because the

\footnotetext{
${ }^{3}$ The journal of the Libertarian Society of Sydney University, 1960-79.
} 
stakes are so small'. Dave was particularly scathing about the professoriate (another favourite saying was that "one can always find professors of economics to support the silliest of propositions and to oppose the most sensible"). He gleefully pointed out that since a major ARC grant had been awarded to two Economics professors at his institution for 'fixing' Australia's current account deficits and external debt problems, the opposite had happened! The last straw was the appointment of a certain fellow former honours student as Professor of Economics at UNSW. Dave figuratively threw in the towel and headed off to journalism - ostensibly on leave from the university.

Dave revelled in the public eye. It has been said that 'journalism is the first draft of history' and he was in a unique position to experience and immerse himself in the politics of economic policy, often siding with politicians like Peter Walsh, whose 1995 memoirs, Confessions of a Failed Finance Minister, beautifully capture Dave's views during this time.

As leader writer for the Australian Financial Review from 1983-86, Dave published over 600 editorials on topics ranging from the Federal budget and Federal and State elections, to taxation and superannuation, immigration, AIDS, the arts, education, and business ethics. He claimed that these editorials were unusual in that they were not just 'opinions without facts' but 'opinions backed up with lots of facts and analysis'. He even succeeded in publishing the only leader ever published in Australia which included an equation. Thereafter, he worked as a columnist for the same newspaper from 1986-95. His column "On the Other Hand" ran without break over this period, making it one of the longest-running, continuous columns in an Australian newspaper. Its philosophy was that there is always another side to every question, and that all arguments need close, critical examination. Another of his favourite sayings about economic and social policy matters was that 'every complex problem has a simple solution, and it's always wrong'.

Dave described himself as caught on the barbed-wire fence between academia and journalism but 'having lots of fun'. He divided his time between the two, because he believed 'economics is far too important to be left to the gnawing criticism of the university library mice and academic seminar rooms'. Dave's experiences with academia hardened his belief in the importance of the work he was doing for high school students. He ran the Commonwealth Bank/Australian Financial Review lectures for Economics students around Australia - in some years he spoke at 15 different venues to total audiences exceeding 7500 students. ${ }^{4}$ His AFR Student Economics Briefs, 1986-99, ran monthly and were sponsored by the Commonwealth Bank. They were then updated, expanded and published in book form. He was also author of the $A F R$

\footnotetext{
${ }^{4}$ For many years he conducted graduate courses for the Australian Defence College, the Australian Army and the RAAF.
} 
Economic Update, 1986-97, a monthly overview of the economy and the AFR annual book guide to the economy, Economic Update. Combined sales of the Update and Briefs volumes were between 700000 and 750000 copies. He used this to support his proposition that he was the most published economist in the country!

His final two decades were greatly enriched through his partnership with Annette Larke. He was also, in his last years, the economics columnist for Personal Investor magazine (1996-2005) and Asset magazine (2000-05). His media appearances should be noted. The last radio program Dave was involved in was in February 2008, with Max Walsh on ABC CounterPoint titled 'Remembering Paddy McGuinness'.5

Dave lived his life hard, and with great enjoyment. He loved the good life, travel, a good yarn and a booze-up with friends. He had a commanding, even intimidating, physical presence and enjoyed public debate and confrontations immensely. Never able to suffer fools gladly, he enjoyed critical discussion and salacious gossip. He could be very cutting, and for that reason slighter souls avoided him or could stomach his sometimes outlandish statements in only small doses. But he was an affable character, bubbling with energy, his booming laugh and confident tone only serving to underline the impression that he was one of those rare individuals who can make our most complex of subjects simple to understand.

\section{References}

Clark, D. 1978, 'Worse then Physic: Sydney's Water Supply 1788-1888' in Nineteenth-century Sydney: Essays in Urban History, edited by Max Kelly, Sydney: Sydney University Press.

Clark, D. 1984a, 'Confronting the Linear Imperialism of the Austrians: Lowe's Contribution to Capital and Growth Theory', Eastern Economic Journal 10(2): 107-27.

Clark, D. 1984b, 'On the Origins of Growth and Planning Theory', Journal of Contemporary Asia 14(3).

${ }^{5}$ At: http://www.abc.net.au/rn/counterpoint/stories/2008/2153477.htm 








\section{Gregory Clark, A Farewell to Alms}

\section{(Princeton University Press, 2007)}

\section{Declan Trott $^{1}$}

For most of human history, material living standards have been static. But over the last century or two, large parts of the world have broken away from this equilibrium and enjoyed massive increases in income. Gregory Clark sets himself to answer three big questions: Why did living standards stagnate for so long? What allowed England to be the first country to break the trap? And why were some countries able to follow and surpass the leader while others have become even worse off?

His answer to the first question is that of Malthus: any increase in living standards was ultimately eaten up by an increasing population facing diminishing returns. Thus the labouring Englishman (or woman) of 1800 was, in terms of stature, diet and leisure, worse off than a Stone Age hunter-gatherer, or indeed his counterpart of 1400 who benefited from the shortage of workers following the Black Death. The many advances in productive technology that occurred before that time merely served to increase population.

While this Malthusian argument is an old one, Clark illustrates it with a wealth of historical data on population and living standards, and a simple graphical model which illustrates starkly the inversion of economic vice and virtue in this world: war and disease raise per capita incomes, while peace and hygiene lower them. Thus 'Europeans were lucky to be a filthy people who squatted happily above their own faeces'.

How did England escape? Clark argues that the usual explanations are all unsatisfactory. Invoking the Enlightenment, Protestant Reformation or Scientific Revolution merely pushes the question back one stage, even if the link is valid. The timing of changes in family size and the skill premium does not fit human-capital-based explanations, while it is hard to find evidence of any institutional changes at the crucial time. Intellectual property was still very poorly protected (many of the great textile inventors died in poverty) while the other elements of a market-based economy had been in place for centuries. Indeed, Clark argues that, by many measures, medieval England had better economic incentives than England today - lower taxes, inflation and government debt, a higher skill premium, and fewer restrictions on land use. The Industrial

\footnotetext{
${ }^{1}$ School of Economics, College of Business and Economics, Australian National University, Declan.Trott@anu.edu.au
} 
Revolution saw a massive increase in the supply of innovations without any apparent change in incentives.

There were, however, four crucial changes over this time. Interest rates fell from double to single digits. Literacy rose. Society became much less violent. And work became longer and more disciplined. This environment rewarded middle-class values of patience, diligence, acquisitiveness and self-control. Clark suggests that these values were, in fact, being biologically selected for: the rich had more surviving children than the poor, and their children inherited their values, whether by genetic or cultural mechanisms. It was the long-run evolutionary change in the character of the people, rather than any short-run change in policies or institutions, that did the trick. This has the merit of focusing on differences between England, on the one hand, and Asia on the other: while Japan, China and India did have many of the same market institutions, they still had higher interest rates and lower literacy. What data is available for China and Japan also suggest that the rich enjoyed a much smaller reproductive advantage in those countries, perhaps linked to the fact that their populations quadrupled or quintupled between 1300 and 1750, while England barely recovered its losses from the plague.

This leads naturally to the third question: why the Great Divergence? Poor countries, especially colonies, had the cheapest labor in the world; security of property; complete freedom to import technicians, machinery, capital ... sea routes; and access to the largest market in the world'. This sounds like an optimistic list of China's advantages 10 or 20 years ago. Why were the results not similar?

Clark's answer is labour quality. Using mainly evidence from the textile industry, he argues that low-wage countries had much higher labour-output ratios (as would be expected given relative prices), but not lower capital-output ratios. It seems that in low-wage countries more workers had to be used on the same machines to get the same output, even with imported technicians and managers. This would only be rational if the low-wage workers were intrinsically less efficient: less diligent, less punctual and less disciplined; and there are plenty of recorded complaints along those lines. Thus investing in low-wage countries was not particularly profitable, and there was no tendency for incomes to converge. Indeed, since modern medicine has reduced mortality at any given level of income, we can have societies such as the poorest in sub-Saharan Africa in which the population continues to grow, despite the lowest living standards anywhere in recorded history.

To recap: England had the Industrial Revolution because of natural selection, and poor counties are poor because their workers are intrinsically less productive. This is a bold pair of hypotheses, which would no doubt attract vociferous condemnation even if backed by watertight evidence and presented in the most 
modest and unassuming way. This they emphatically are not. Confining our attention to substance rather than style, the evidence is thin on crucial points, and could bear other interpretations. On the question of inheritance of productive characteristics, rather than simply cash and connections, there is only an unreferenced and unadorned statement that rich fathers tended to have rich sons, even when the inheritances were made insignificant by large families. There is also no attempt to show that the theory is quantitatively consistent with the observed selection pressure of income and plausible values of inheritability. The textile productivity data could be explained by efficiency wages, or climate, or the employment of assertive men rather than docile girls.

Further, it seems natural at a broader level to link natural selection and labour quality, and so turn Clark's two theories into one. However, this sits uneasily with the variability of growth in individual countries across time, as Clark admits: 'Regarding the underlying cause of the differences in labour quality, there is no satisfactory theory. Economies seem ... to alternate more or less randomly between relatively energetic phases and periods of somnolence.' Clark also mentions the huge increase in earnings enjoyed by workers moving from the Third World to the First, without seeming to notice the obvious problem this poses for the labour-quality theory.

But if the natural-selection theory, on the admission of its author, is a poor explanation for variation in labour quality across countries and time, it seems doubly poor as an explanation for the Industrial Revolution in England. If this is viewed, as Clark does, as an upsurge in the supply of innovation without any change in demand, the connection with bourgeois values seems rather weak. Even if these values are inherited and selected for, it is hard to see how patience, workaholism and pacifism lead automatically to innovation. One could even argue that they would crush it or crowd it out. And since innovators in the preand early industrial era typically received meagre rewards, selection directly on innovation is even less plausible. One could perhaps make a case for selection on literacy reaching a critical point that allowed communication of ideas and thus continuous, sustained innovation, but then we are back in the world of the discontinuous, one-off Enlightenment/Revolution/Revolution theories that Clark abhors.

Perhaps, however, this is where we should be. After all, the Industrial Revolution was a one-off, discontinuous historic event. ${ }^{2}$ We can increase our understanding of this event by careful study of the place and time where it happened, and places and times where it didn't, but until we invent a time

2 The demographic transition to lower, deliberately controlled, fertility that allows final escape from the Malthusian trap is not, but existing theories seem to explain this pretty well, and Clark adds little or nothing. 
machine to move between parallel universes there will always be a bit of mystery remaining.

Even if the answers are unsatisfactory, however, the questions remain. And A Farewell to Alms does a great job of posing the questions. It also contains many insights on the timing, composition, demographics and beneficiaries of the Industrial Revolution. This book deserves everything it gets, both in praise and in blame. 


\title{
Barber, William J., Gunnar Myrdal. An Intellectual Biography
}

\section{(Palgrave Macmillan, 2008)}

\author{
Selwyn Cornish ${ }^{1}$
}

Gunnar Myrdal. An Intellectual Biography is part of Palgrave Macmillan's Great Thinkers in Economics series. ${ }^{2}$ Under the general editorship of A. P. Thirlwall, the intention of the series is not to provide complete biographies, but to focus specifically on the writer's contributions to economics. William J. Barber, the author of Gunnar Myrdal, has written a number of distinguished books on the history of economic thought and the history of economic policy. Barber discloses in the Preface that he was part of Myrdal's research team for one of his major works, Asian Drama: An Inquiry into the Poverty of Nations.

In the early 1930s Myrdal published, in quick succession, two works which created his reputation as an economic thinker. In The Political Element in the Development of Economic Theory he dismissed the frequent assertion by theoretical economists that their work was free from subjective judgments, and questioned whether writing in economics could ever be free from value judgments. In his Monetary Equilibrium, starting from Wicksell, he drew attention to variations between the 'natural' and 'market' rate of interest. ${ }^{3}$ If the market rate fell below the natural rate, investment would increase and prices would rise; the reverse sequence would induce a decline in prices. His own contribution was the importance that he attached to the separate roles of saving and investment, and the relationship between them, which could differ at different points within a cumulative movement.

Barber points out that it was the translator of Myrdal's Monetary Equilibrium from Swedish to German who coined the expressions ex ante and ex post. These terms were to be used frequently after the publication of Keynes' General Theory to explain how an initial imbalance between the propensity to save and the propensity to invest could induce a change in output, leading to a new equilibrium between saving and investment. In other words, there could be an

\footnotetext{
${ }^{1}$ The School of Economics, College of Business and Economics, Australian National University, Selwyn.Cornish@anu.edu.au.

2 Other books in the series include studies of the intellectual contributions of Keynes, Marshall, Schumpeter, Modigliani, Buchanan, Marx, Kaldor, Sraffa, Kalecki, Galbraith, Harrod, Pigou, Joan Robinson and her Circle, Solow, Smith and Robertson.

3 The former being the rate of return on capital, while the latter was the rate of interest that prevailed in the market place.
} 
imbalance, ex ante, between saving and investment, but they would equilibrate, ex post, as a result of a change in economic activity.

Myrdal highlighted that, although some of these ideas had been developed earlier by Swedish writers (including Wicksell), they had been taken up by British writers, including D. H. Robertson in Banking and the Price Level and by Keynes in his A Treatise on Money. To Myrdal, the failure to acknowledge developments in Swedish economic thinking was an example of what he called the 'attractive Anglo-Saxon kind of unnecessary originality'. Barber rightly devotes a considerable amount of space to reviewing the debate as to whether Swedish economists of the 1920s and early 1930s anticipated Keynes, and whether the 'Keynesian revolution' should more properly be termed the 'Myrdal-Keynes revolution'.

Barber himself seems to suggest that Myrdal is entitled to a share in the authorship of this revolution. But he has neglected Don Patinkin's work on anticipations of the General Theory, which, to this reviewer, convincingly demonstrated that it was Keynes who made the decisive breakthrough by focusing on changes in output as the equilibrating mechanism between saving and investment, rather than changes in prices, as Myrdal had argued (and as Keynes himself had earlier proposed in The Treatise on Money). Similarly, in reviewing the literature on the advocacy of public expenditure as a device to expand employment, Barber fails to mention that Keynes as early as 1924 was advocating increased expenditure on public works. This was almost a decade before Myrdal began to call for similar programs of public expenditure for the purpose of alleviating unemployment.

In 1934, together with his wife Alva, Myrdal published the results of an investigation of the slowdown in population growth in Sweden and its implications for the preservation of economic stability. Later, in 1938, the problems associated with a slowdown in population growth formed the basis of Gunnar Myrdal's Godkin Lectures delivered at Harvard University. The conclusion of all this work was that a faster rate of population growth would enhance economic stability through the additional demand for goods and services, especially for consumption goods. It was stressed that the costs of extra children would impose a heavy financial burden, especially upon lower-income families. The Myrdals argued that the government should assist such families by subsidising their medical, educational and other costs. In making these recommendations, Barber suggests that Gunnar and Alva Myrdal were the principal architects of Sweden's welfare state.

Perhaps Myrdal's most enduring contribution to human society was his work for the Carnegie Foundation on the condition of the American Negro. Entitled An American Dilemma: The Negro Problem and Modern Democracy, Myrdal's report, published in 1944, was highly influential in ending aspects of racial 
discrimination in the United States through judgments by the Supreme Court, of which the decision in the case of Brown versus the Board of Education of Topeka in 1954 constituted the major breakthrough. Myrdal's key argument that there was an inconsistency at the heart of the American 'creed' between the ideals of human freedom as expressed in the Declaration of Independence and the American Constitution, and the reality of American life as demonstrated by official discrimination against Afro-Americans - was frequently cited before the Supreme Court and in the movement for racial equality led by Martin Luther King and other advocates of civil rights. Barber is highly persuasive in demonstrating the extraordinary power of Myrdal's argument and the validity of his conclusion that equality for Afro-Americans would never be achieved until the removal of discrimination allowed them to participate in the mainstream of American life.

Following his brief and unsuccessful appointment as Sweden's Minister for Commerce between 1945 and 1947, Myrdal spent 10 years as the inaugural head of the Economic Commission for Europe, an agency of the United Nations, where he created one of the world's leading centres for the conduct of applied economic research and policy advice. On leaving the Commission in 1957, Myrdal embarked upon his final major work; the three-volume study of economic development in south and south-east Asia entitled Asian Drama. As with An American Dilemma, Myrdal was able to attract funding from an American philanthropy, this time the Twentieth Century Fund.

India was the country that attracted most of his attention, being the largest country in the region and the one most committed to accelerating economic growth and development at the time that he commenced to work on the project. Considerable attention was directed to institutional difficulties that were inhibiting economic advancement, such as public corruption, the need for land reform, social institutions such as India's caste system, and the insufficient attention that was paid to poverty reduction and educational advancement. The importance of promoting agricultural productivity was given special attention, though Myrdal also argued that industrial development should be promoted by encouraging import replacement.

For several reasons, the massive Asian Drama did not have the impact of $A n$ American Dilemma. One problem was that it lacked a central, unifying theme, such as the idea of incongruity between ideals and reality which lay at the heart of An American Dilemma. Instead, Asian Drama was somewhat disorganised, and deficient in its application of economic analysis. And it failed to recognise the benefits that were soon to be derived by those developing countries that had commenced to open their economies to international trade and to market forces generally. 
Barber examines in varying degrees of depth most of Myrdal's contributions to economics. He reveals the enormous range and originality of Myrdal's work and highlights the fact that Myrdal exhibited both initiative and courage in discovering and developing new fields of research interest and applying novel research methods. This is what the Swedish Academy had stressed in its citation for the Nobel Prize in Economics, that Myrdal won (jointly with Friedrich von Hayek) in 1974.

Myrdal himself came to regret his acceptance of the Nobel Prize. Though he had been one of the strongest advocates of a prize for economics, he later thought that this was a mistake. In particular, he believed that the selection committee had favoured a certain type of economist, one that had a somewhat narrow conception of how the study of economics should be undertaken. As for his sharing of the prize with Hayek, Myrdal later was inclined to agree with members of his family and his closest colleagues that the selection committee had indulged itself in something of a private joke. While they admitted that Myrdal's name had been raised as a possible recipient each year since the prize for economics had been created, they also acknowledged that Myrdal had strong critics in the economics profession because of his political views, his criticism of conventional methods used in economic analysis and for his tendency to stray outside the mainstream of the discipline. Why not award him the Nobel Prize but award it jointly with an economist from the other side of the political spectrum?

As one would expect from William Barber, this is a well-constructed, clearly written and highly competent work. He has largely succeeded in executing his aim, which was to write 'an intellectual biography of one of the most creative and influential economic thinkers of the twentieth century'. Myrdal's work will not appeal to everyone who is interested in the evolution of economic thought and policy, but his coverage was such - from pure theory to institutional economics and economic sociology - that there will be enough in the book to sustain the interest of most readers. A reading of it might encourage someone to write a comprehensive biography of Myrdal. 


\section{John Creedy, Research Without Tears: From the First Ideas to Published Output}

\section{(Edward Elgar Publishing, 2008)}

\section{Farshid Vahid ${ }^{1}$}

Research Without Tears is a collection of talks by John Creedy on three topics: 'A First Research Paper', 'Working on a PhD' and 'Publishing Research'. These essays contain general advice drawn from a lifetime of experience by a senior Australian academic and passed on to the future generation of researchers. The book is most useful for $\mathrm{PhD}$ students who are about to begin the research component of their PhD studies. The third essay is also useful for those at the beginning of their academic careers. Another group that can benefit from this book are those academics who, as a result of a run of good publications and success in supervising a handful of PhD students, get promoted to full professors and soon after are asked to give talks on research, $\mathrm{PhD}$ supervision and publishing.

All universities in Australia offer a series of talks on research and publishing for PhD students and staff every year, and typescripts or slides of most of these talks can be downloaded freely from the Internet. So, it seems that this book may have many close substitutes that are free. But I particularly like this book more than most other essays on the topic for two reasons: (i) it does not pretend that any part of the research production process is easy, and (ii) it is written for the middle rather than extreme right or left tails of the distribution of $\mathrm{PhD}$ students. I will elaborate these in turn.

Despite the title, Creedy never implies that any part of the journey from finding the first ideas to publishing the output is simple. In fact, he is quite explicit that every stage of the process can be difficult and frustrating; and he emphasises that, in order to increase the possibility of success, one needs intense concentration and effort over a long period of time, often longer than expected. Reading the book, a reader will conclude that during the journey from the first ideas to published output, it is quite natural to cry, be it from frustration or from joy.

\footnotetext{
${ }^{1}$ The School of Economics, The College of Business and Economics, The Australian National University, Farshid.Vahid@anu.edu.au
} 
The second reason I like this book is because it reflects that Creedy has tried to draw robust conclusions from his vast experience in research and supervision, and because of that the book is likely to be helpful for most PhD students. In contrast, many talks on advice for PhD students, especially talks given by relatively inexperienced academics, are tainted by a small number of outlying observations. In such talks, we often hear "Do not disappear for six months at a time" or "Do not go to see your supervisor when you are drunk" - which although amusing and funny, are definitely reactions to a single extreme observation (who is probably not attending the talk) and a waste of time for the audience. There is just one occasion where Creedy seems to fall into this trap. In Chapter 4 he writes: "If you think your supervisor is wrong about something, do not argue but express your desire to rewrite your analysis more clearly for future discussion." This is likely to be based on an unpleasant experience with a single outlying student. It is strange because it does not specify what the student should do in the next meeting when she goes back with revised analysis still thinking that her supervisor is wrong. Should she argue or not? Or is this advice based on the assumption that supervisors are never wrong (an assumption that is certainly false)?

One common piece of advice on writing that is missing from the book is 'Do not trust automatic spell-checkers and typesetting software'. Good examples of what can go wrong are in evidence in the Preface of this book, where we see 'regu-lation' and 'encourage-ment', and reference to 'Greedy (2001, 2006, 2007)'. To be fair, these are exceptions. The book is well-written, and other than in the Preface, properly proof-read.

I concur with most advice given in the book and I suggest to all PhD students that they add this book to their list of 'recommended reading'. But I emphasise to them that this is not a substitute for their 'required reading': The Craft of Research by Booth, Colomb and Williams, published by the University of Chicago Press. 